\title{
MODUL PEMBELAJARAN PERUNDANG-UNDANGAN PENDIDIKAN
}

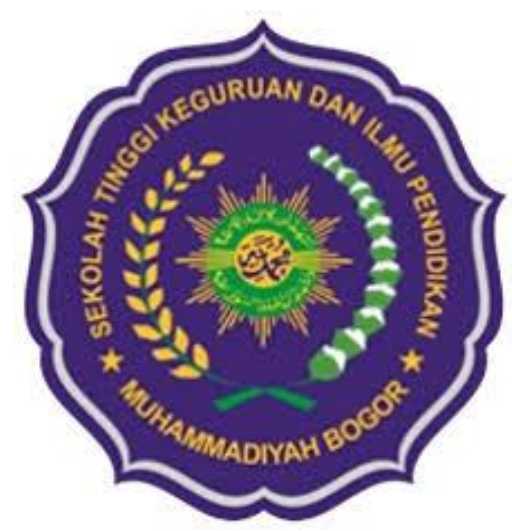

Oleh

WAHYU BAGJA SULFEMI

PROGRAM STUDI ADMINISTRASI PENDIDIKAN STKIP MUHAMMADIYAH BOGOR BOGOR 2019 


\section{KATA PENGANTAR}

Alhamdulillah puji syukur kehadirat Allah SWT yang telah melimpahkan rahmat, rizki dan hidayah-Nya, sehingga penulis dapat menyelesaikan diktat ini. Adapun penyusunan diktat ini merupakan hasil ersama dengan mahasiswa semester 2 yang sedang melaksanakan perkuliahan Perundang-undangan pendidikan.

Penyusunan modul ini sebagai bahan pembelajaran dalam mata kuliah Perundang-Undangan Pendidikan di Program Studi Administrasi Pendidikan Sekolah Tinggi Keguruan dan Ilmu Pendidikan (STKIP) Muhammadiyah Bogor. Mata Kuliah Perundang-undangan Pendidikan adalah mata kuliah wajib diikuti dengan beban 2 sks.

Keberhasilan penulis dalam menyelesaikan diktat ini tidak lepas dari bantuan dan partisipasi berbagai pihak. Untuk itu penulis ingin menyampaikan ucapan terima kasih kepada :

1. Kepada seluruh Dosen dan staf STKIP Muhammadiyah Bogor.

2. Mahasiswa Administrasi pendidikan semester 2

3. Kedua orang Tua tercinta

4. Seluruh Keluarga dan anak tercinta

Semoga Allah SWT membalas kebaikan dan ketulusan semua pihak yang telah membantu menyelesaikan skripsi ini dengan melimpahkan rahmat dan karuniaNya. Dalam penyusunan karya tulis ini, penulis menyadari masih ada kekurangan dan masih jauh dari kata sempurna. Oleh karena itu kritik dan saran yang masih sifatnya membangun dari semua pihak sangat penulis harapkan. Semoga diktat ini dapat memberikan manfaat dan kebaikan bagi banyak pihak demi kemaslahatan bersama, serta bernilai ibadah dihadapan Allah SWT. Amin

Bogor, Maret 2019

Wahyu Bagja Sulfemi, S.S., M.Pd. 


\section{SILABUS}

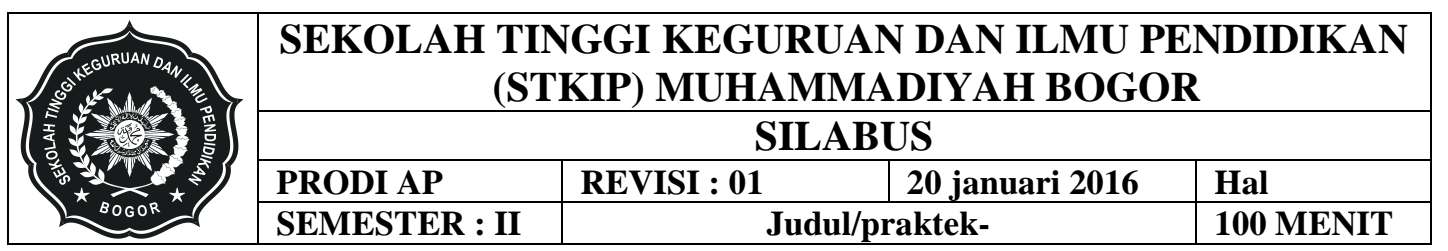

\section{Identitas Mata Kuliah}

Nama Mata Kuliah

Kode Mata Kuliah

Jumlah SKS

Semester

Kelompok Mata Kuliah

Program Studi/Program

Status Mata Kuliah

Dosen Pengampu

NIK
: Perundang-Undangan Pendidikan

: 1401030147

: 2 (dua)

: 2 (dua)

: Mata Kuliah Bidang Keahlian (MKBK)

: Administrasi Pendidikan

: Wajib

: Wahyu Bagja Sulfemi, S.S., M.Pd.

: 19751120020

\section{Deskripsi Isi}

Mata Kuliah Perundang-Undangan Pendidikan membekali mahasiswa dengan wawasan wawasan teoritis dan praktis dalam Perundang-Undangan Pendidikan yangmencakup konsep,masalah dan prospeknya dalam penyelenggaraan pendidikan di Indonesia serta kemampuandalam menganalisis dan mensikapi segala bentuk Perundang-Undangan Pendidikan diIndonesia. Adapun untuk mencapai hal itu materi yang diberikan berisi tentang; a) KonsepPerundangUndangan Pendidikan, b) Perkembangan Historis PUUP, c) Fungsi dan HierarkiPUUP, d) Prosedur penyusunan PUUP, e) Perundang-undangan dan kebijakan pemerintah, dan f) Berbagai Peraturan Perundangan Dalam Bidang Pendidikan

\section{Capaian Mata Kuliah}

Tujuan Mata Kuliah Perundang-Undangan Pendidikan ini adalah sebagai berikut:

a. Memberikan landasan pemikiran tentang konsep dan teori perundangundangan pendidikan.

b. Membekali mahasiswa dalam menganalisis produk-produk hukum dalam bidangpendidikan.

c. Mengkonsolidasikan teori dalam penyusunan perundangan dalam bidang pendidikan.

d. Membekali mahasiswa dengan kemampuan dalam melakukan analisis terhadap produk-produk hukum dalam bidang pendidikan

\section{Pendekatan Pembelajaran}

$\begin{array}{ll}\text { Metode } & : \text { 1. Tatap Muka ceramah, tanya jawab, diskusi kelompok, } \\ & \text { 2. Belajar Mandiri } \\ \text { Media } & : \text { Media sederhana dan Multimedia } \\ \text { Tugas } & \begin{array}{l}: \text { 1. Tugas Mandiri } \\ \text { 2. Tugas Terstruktur }\end{array}\end{array}$




\section{Komponen Evaluasi}

a. Nilai Makalah dan Diskusi Individu/Kelompok

b. Tugas Mandiri

c. Kehadiran

d. UTS

e. UAS

\section{Rincian Meteri Perkuliahan Tiap Pertemuan}

\begin{tabular}{|c|c|c|c|}
\hline Pertemuan & $\begin{array}{c}\text { Pokok } \\
\text { Bahasan }\end{array}$ & Kompetensi Dasar & Indikator \\
\hline 1 & $\begin{array}{l}\text { Orientasi } \\
\text { Perkuliahan }\end{array}$ & $\begin{array}{l}\text { Mahasiswa memahami } \\
\text { pola, strategi dan tujuan } \\
\text { yang ingin dicapai dari } \\
\text { mata kuliah PUUP }\end{array}$ & $\begin{array}{l}\text { - Paham tujuan yang ingin } \\
\text { dicapai dari mata kuliah } \\
\text { - Paham proses yang harus } \\
\text { ditempuh } \\
\text { - Dapat Belajar dengan baik }\end{array}$ \\
\hline 2 & $\begin{array}{l}\text { Hakekat } \\
\text { Manusia } \\
\text { sebagai } \\
\text { Individu } \\
\text { dan } \\
\text { Kelompok }\end{array}$ & $\begin{array}{l}\text { Mahasiswa memiliki } \\
\text { pemahaman yang } \\
\text { komprehensif tentang } \\
\text { hakekat manusia } \\
\text { sebagai individu \& } \\
\text { kelompok }\end{array}$ & $\begin{array}{l}\text { - Paham hakekat individu dan } \\
\text { kelompok dalam kehidupan } \\
\text { - Paham proses pembentukan } \\
\text { kelompok }\end{array}$ \\
\hline 3 & $\begin{array}{l}\text { Konsep } \\
\text { PerundangU } \\
\text { ndangan } \\
\text { Pendidikan }\end{array}$ & $\begin{array}{l}\text { Mahasiswa memiliki } \\
\text { pemahaman tentang } \\
\text { pendidikan secara } \\
\text { komprehensif dari sudut } \\
\text { pandang produk-produk } \\
\text { hukum pendidikan }\end{array}$ & $\begin{array}{l}\text { - Pamaham konsep perturan } \\
\text { dalam kehidupan } \\
\text { - Pemahaman tentang } \\
\text { Peraturan tertulis dan } \\
\text { peraturan tidak tertulis } \\
\text { - Paham landasan yang } \\
\text { digunakan dalam } \\
\text { pembentukan perturan } \\
\text { perundangan }\end{array}$ \\
\hline 4 & $\begin{array}{l}\text { Perkembang } \\
\text { an Historis } \\
\text { PUUP }\end{array}$ & $\begin{array}{l}\text { Mahasiswa memiliki } \\
\text { pemahaman tentang } \\
\text { pola perkembangan } \\
\text { peraturan perundangan } \\
\text { dalam perjalanan } \\
\text { pendidikan di Indonesia }\end{array}$ & $\begin{array}{l}\text { - Pengetahuan tentang } \\
\text { perkembangan perturan } \\
\text { perundangan dalam bidang } \\
\text { pendidikan } \\
\text { - Pemahaman tentang } \\
\text { perubahan setiap tahapan } \\
\text { dalam perubahan perturan } \\
\text { perundangan pendidikan }\end{array}$ \\
\hline 5 & $\begin{array}{l}\text { Fungsi dan } \\
\text { Hierarki } \\
\text { PUUP }\end{array}$ & $\begin{array}{l}\text { Mahasiswa memiliki } \\
\text { pemahaman tentang } \\
\text { fungsi dan tingkatan } \\
\text { dalam peraturan } \\
\text { perundangan (PUUP) }\end{array}$ & $\begin{array}{l}\text { - Pemahaman tentang fungsi } \\
\text { peraturan perundangan } \\
\text { dalam bidang pendidikan. } \\
\text { - Pemahaman tentang } \\
\text { peraturan perundangan } \\
\text { pendidikan dalam struktur } \\
\text { hirarki peraturan } \\
\text { perundangan }\end{array}$ \\
\hline
\end{tabular}




\begin{tabular}{|c|c|c|c|}
\hline 6 & $\begin{array}{l}\text { Prosedur } \\
\text { penyusunan } \\
\text { PUUP }\end{array}$ & $\begin{array}{l}\text { Mahasiswa memahami } \\
\text { setiap tahapan dalam } \\
\text { penyusunan peraturan } \\
\text { khususnya peraturan } \\
\text { dalam bidang } \\
\text { pendidikan }\end{array}$ & $\begin{array}{l}\text { Pemahaman tentang alur } \\
\text { dan tingkatan dalam } \\
\text { penyusunan peraturan } \\
\text { perundangan pendidikan }\end{array}$ \\
\hline 7 & $\begin{array}{l}\text { Perundang- } \\
\text { undangan } \\
\text { dan } \\
\text { kebijakan } \\
\text { pemerintah }\end{array}$ & $\begin{array}{l}\text { Mahasiswa memahami } \\
\text { tentang posisi } \\
\text { perundangundangan } \\
\text { sebagai produk kebijak }\end{array}$ & $\begin{array}{l}\text { - Pemahaman tentang } \\
\text { posisiperundang-undangan } \\
\text { sebagai produk kebijak }\end{array}$ \\
\hline 8 & \multicolumn{3}{|l|}{ UTS } \\
\hline 9 & $\begin{array}{l}\text { Pengelolaan } \\
\text { Pendidikan } \\
\text { (Permendik } \\
\text { nas } \\
\text { 19/2007) }\end{array}$ & $\begin{array}{l}\text { Mahasiswa mampu } \\
\text { menganalisis } \\
\text { permendiknas nomor } 19 \\
\text { tahun } 2007\end{array}$ & $\begin{array}{l}\text { - Pemahaman tentang } \\
\text { pengelolaan pendidikan } \\
\text { ditinjau dari permendiknas } \\
\text { nomor } 19 \text { tahun } 2007\end{array}$ \\
\hline 10 & $\begin{array}{l}\text { Pembiayaan } \\
\text { Pendidikan } \\
\text { (Peraturan } \\
\text { Pemerintah } \\
\text { 48/2008) }\end{array}$ & $\begin{array}{l}\text { Mahasiswa mampu } \\
\text { menganalisis Peraturan } \\
\text { Pemerintah 48/2008 }\end{array}$ & $\begin{array}{l}\text { - Pemahaman tentang } \\
\text { pendanaan dalam } \\
\text { pendidikan pada unit } \\
\text { persekolahan berdasarkan } \\
\text { Peraturan Pemerintah No. } \\
48 \text { Tahun } 2008\end{array}$ \\
\hline 11 & $\begin{array}{l}\text { Profesionali } \\
\text { sme Guru } \\
\text { (UU } \\
14 / 2005, \text { PP } \\
74 / 2008 \text { ) }\end{array}$ & $\begin{array}{l}\text { Mahasiswa mampu } \\
\text { menganalisis UU } \\
\text { 14/2005, PP 74/2008 }\end{array}$ & $\begin{array}{l}\text { - Pemahaman tentang } \\
\text { pengelolaan tenaga } \\
\text { pendidik khususnya guru } \\
\text { berdasarkan Undang- } \\
\text { Undang Nomor } 14 \text { Tahun } \\
2005 \text { dan Peraturan } \\
\text { Pemerintah Nomor } 74 \\
\text { Tahun } 2008\end{array}$ \\
\hline 12 & $\begin{array}{l}\text { Kurikulum } \\
\text { Tingkat } \\
\text { Satuan } \\
\text { Pendidikan } \\
\text { (Permendik } \\
\text { nas } \\
\text { 22,23,24/20 } \\
06 \text { ) } \\
\end{array}$ & $\begin{array}{l}\text { Mahasiswa mampu } \\
\text { menganalisis } \\
\text { Permendiknas } \\
\text { 22,23,24/2006 }\end{array}$ & $\begin{array}{l}\text { Pemahaman tentang } \\
\text { pengelolaan kurikulum } \\
\text { (KTSP) berdasarkan } \\
\text { Permendiknas Nomor } \\
\text { 22,23,24 tahun } 2006\end{array}$ \\
\hline 13 & $\begin{array}{l}\text { Profesionali } \\
\text { sme Kepala } \\
\text { Sekolah } \\
\text { (Permendik } \\
\text { nas } \\
13 / 2007 \text { ) }\end{array}$ & $\begin{array}{l}\text { Mahasiswa mampu } \\
\text { menganalisis } \\
\text { Permendiknas 12/2007 }\end{array}$ & $\begin{array}{l}\text { - Pemahaman tentang } \\
\text { kepengawasan/supervisi } \\
\text { berdasarkan Permendiknas } \\
\text { Nomor } 12 \text { Tahun } 2007\end{array}$ \\
\hline 14 & $\begin{array}{l}\text { Profesionali } \\
\text { sme } \\
\text { Pengawas }\end{array}$ & $\begin{array}{l}\text { Mahasiswa mampu } \\
\text { menganalisis } \\
\text { Permendiknas 13/2007 }\end{array}$ & $\begin{array}{l}\text { - Pemahaman tentang } \\
\text { profesionalisme } \\
\text { pengelolaan kepala }\end{array}$ \\
\hline
\end{tabular}




\begin{tabular}{|c|l|l|l|}
\hline & $\begin{array}{l}\text { Pendidikan } \\
\text { (Permendik } \\
\text { nas } \\
12 / 2007)\end{array}$ & & $\begin{array}{l}\text { sekolah berdasarkan } \\
\text { Permendiknas Nomor 13 } \\
\text { Tahun 2007. }\end{array}$ \\
\hline 15 & $\begin{array}{l}\text { Refleksi } \\
\text { Akhir }\end{array}$ & $\begin{array}{l}\text { Mahasiswa memiliki } \\
\text { pemahaman yang } \\
\text { komprehensif tentang } \\
\text { PUUP }\end{array}$ & $\begin{array}{l}\text { - Penguasaan secara } \\
\text { komprehensif tentang } \\
\text { konsep dan aplikasi } \\
\text { praturan perundangan } \\
\text { dalam bidang pendidikan }\end{array}$ \\
\hline 16 & UAS & & \\
\hline
\end{tabular}




\section{Rencana Pembelajaran Semester (RPS)}

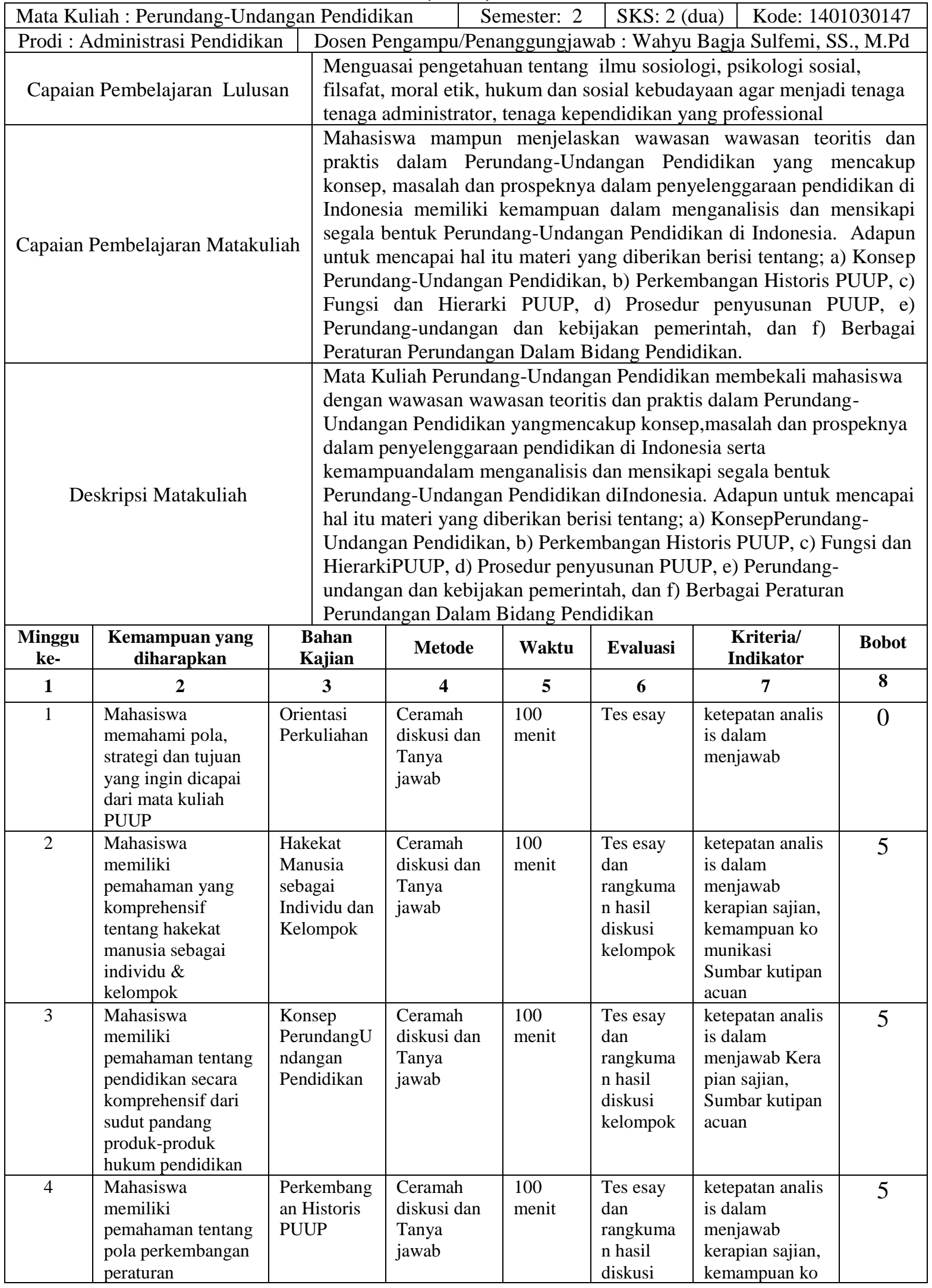




\begin{tabular}{|c|c|c|c|c|c|c|c|}
\hline & $\begin{array}{l}\text { perundangan dalam } \\
\text { perjalanan } \\
\text { pendidikan di } \\
\text { Indonesia }\end{array}$ & & & & kelompok & $\begin{array}{l}\text { munikasi } \\
\text { Sumbar kutipan } \\
\text { acuan }\end{array}$ & \\
\hline 5 & $\begin{array}{l}\text { Mahasiswa } \\
\text { memiliki } \\
\text { pemahaman tentang } \\
\text { fungsi dan tingkatan } \\
\text { dalam peraturan } \\
\text { perundangan } \\
\text { (PUUP) }\end{array}$ & $\begin{array}{l}\text { Fungsi dan } \\
\text { Hierarki } \\
\text { PUUP }\end{array}$ & $\begin{array}{l}\text { Ceramah } \\
\text { diskusi dan } \\
\text { Tanya } \\
\text { jawab }\end{array}$ & $\begin{array}{l}100 \\
\text { menit }\end{array}$ & $\begin{array}{l}\text { Tes esay } \\
\text { dan } \\
\text { rangkuma } \\
\text { n hasil } \\
\text { diskusi } \\
\text { kelompok }\end{array}$ & $\begin{array}{l}\text { ketepatan analis } \\
\text { is dalam } \\
\text { menjawab } \\
\text { kerapian sajian, } \\
\text { kemampuan ko } \\
\text { munikasi } \\
\text { Sumbar kutipan } \\
\text { acuan }\end{array}$ & 5 \\
\hline 6 & $\begin{array}{l}\text { Mahasiswa } \\
\text { memahami setiap } \\
\text { tahapan dalam } \\
\text { penyusunan } \\
\text { peraturan khususnya } \\
\text { peraturan dalam } \\
\text { bidang pendidikan }\end{array}$ & $\begin{array}{l}\text { Prosedur } \\
\text { penyusunan } \\
\text { PUUP }\end{array}$ & $\begin{array}{l}\text { Ceramah } \\
\text { diskusi dan } \\
\text { Tanya } \\
\text { jawab }\end{array}$ & $\begin{array}{l}100 \\
\text { menit }\end{array}$ & $\begin{array}{l}\text { Tes esay } \\
\text { dan } \\
\text { rangkuma } \\
\text { n hasil } \\
\text { diskusi } \\
\text { kelompok }\end{array}$ & $\begin{array}{l}\text { ketepatan analis } \\
\text { is dalam } \\
\text { menjawab } \\
\text { kerapian sajian, } \\
\text { kemampuan ko } \\
\text { munikasi } \\
\text { Sumbar kutipan } \\
\text { acuan }\end{array}$ & 5 \\
\hline 7 & $\begin{array}{l}\text { Mahasiswa } \\
\text { memahami } \\
\text { tentang posisi } \\
\text { perundangundangan } \\
\text { sebagai produk } \\
\text { kebijak }\end{array}$ & $\begin{array}{l}\text { Perundang- } \\
\text { undangan } \\
\text { dan } \\
\text { kebijakan } \\
\text { pemerintah }\end{array}$ & $\begin{array}{l}\text { Ceramah } \\
\text { diskusi dan } \\
\text { Tanya } \\
\text { jawab }\end{array}$ & $\begin{array}{l}100 \\
\text { menit }\end{array}$ & Tes esay & $\begin{array}{l}\text { ketepatan analis } \\
\text { is dalam } \\
\text { menjawab }\end{array}$ & 5 \\
\hline 8 & UTS & & & & & & 15 \\
\hline 9 & $\begin{array}{l}\text { Mahasiswa mampu } \\
\text { menganalisis } \\
\text { permendiknas } \\
\text { nomor } 19 \text { tahun } \\
2007\end{array}$ & $\begin{array}{l}\text { Pengelolaan } \\
\text { Pendidikan } \\
\text { (Permendik } \\
\text { nas } \\
19 / 2007 \text { ) }\end{array}$ & $\begin{array}{l}\text { Ceramah } \\
\text { diskusi dan } \\
\text { Tanya } \\
\text { jawab }\end{array}$ & $\begin{array}{l}100 \\
\text { menit di } \\
\text { kelas } \\
250 \\
\text { menit } \\
\text { untuk } \\
\text { tugas }\end{array}$ & Tes esay & $\begin{array}{l}\text { ketepatan analis } \\
\text { is dalam } \\
\text { menjawab }\end{array}$ & 5 \\
\hline 10 & $\begin{array}{l}\text { Mahasiswa mampu } \\
\text { menganalisis } \\
\text { Peraturan } \\
\text { Pemerintah 48/2008 }\end{array}$ & $\begin{array}{l}\text { Pembiayaan } \\
\text { Pendidikan } \\
\text { (Peraturan } \\
\text { Pemerintah } \\
48 / 2008 \text { ) }\end{array}$ & $\begin{array}{l}\text { Ceramah } \\
\text { diskusi dan } \\
\text { Tanya } \\
\text { jawab }\end{array}$ & $\begin{array}{l}100 \\
\text { menit }\end{array}$ & $\begin{array}{l}\text { Tes esay } \\
\text { dan } \\
\text { rangkuma } \\
\text { n hasil } \\
\text { diskusi } \\
\text { kelompok }\end{array}$ & $\begin{array}{l}\text { ketepatan analis } \\
\text { is dalam } \\
\text { menjawab } \\
\text { kerapian sajian, } \\
\text { kemampuan ko } \\
\text { munikasi } \\
\text { Sumbar kutipan } \\
\text { acuan }\end{array}$ & 5 \\
\hline 11 & $\begin{array}{l}\text { Mahasiswa mampu } \\
\text { menganalisis UU } \\
14 / 2005, \text { PP } \\
74 / 2008\end{array}$ & $\begin{array}{l}\text { Profesionali } \\
\text { sme Guru } \\
\text { (UU } \\
14 / 2005 \text {, PP } \\
74 / 2008 \text { ) }\end{array}$ & $\begin{array}{l}\text { Ceramah } \\
\text { diskusi dan } \\
\text { Tanya } \\
\text { jawab }\end{array}$ & $\begin{array}{l}100 \\
\text { menit }\end{array}$ & $\begin{array}{l}\text { Tes esay } \\
\text { dan } \\
\text { rangkuma } \\
\text { n hasil } \\
\text { diskusi } \\
\text { kelompok, } \\
\text { draft } \\
\text { proposal }\end{array}$ & $\begin{array}{l}\text { ketepatan analis } \\
\text { is dalam } \\
\text { menjawab } \\
\text { kerapian sajian, } \\
\text { kutipan acuan }\end{array}$ & 5 \\
\hline 12 & $\begin{array}{l}\text { Mahasiswa mampu } \\
\text { menganalisis } \\
\text { Permendiknas } \\
22,23,24 / 2006\end{array}$ & $\begin{array}{l}\text { Kurikulum } \\
\text { Tingkat } \\
\text { Satuan } \\
\text { Pendidikan } \\
\text { (Permendik } \\
\text { nas } \\
22,23,24 / 20 \\
06 \text { ) } \\
\end{array}$ & $\begin{array}{l}\text { Ceramah } \\
\text { diskusi dan } \\
\text { Tanya } \\
\text { jawab }\end{array}$ & $\begin{array}{l}100 \\
\text { menit }\end{array}$ & $\begin{array}{l}\text { Tes esay } \\
\text { dan } \\
\text { rangkuma } \\
\mathrm{n} \text { hasil } \\
\text { diskusi } \\
\text { kelompok, } \\
\text { draft } \\
\text { proposal }\end{array}$ & $\begin{array}{l}\text { ketepatan analis } \\
\text { is dalam } \\
\text { menjawab } \\
\text { kerapian sajian, } \\
\text { Sumbar kutipan } \\
\text { acuan }\end{array}$ & 5 \\
\hline 13 & $\begin{array}{l}\text { Mahasiswa mampu } \\
\text { menganalisis } \\
\text { Permendiknas } \\
12 / 2007\end{array}$ & $\begin{array}{l}\text { Profesionali } \\
\text { sme Kepala } \\
\text { Sekolah } \\
\text { (Permendik } \\
\text { nas }\end{array}$ & $\begin{array}{l}\text { Ceramah } \\
\text { diskusi dan } \\
\text { Tanya } \\
\text { jawab }\end{array}$ & $\begin{array}{l}100 \\
\text { menit }\end{array}$ & $\begin{array}{l}\text { Tes esay } \\
\text { dan } \\
\text { rangkuma } \\
\mathrm{n} \text { hasil } \\
\text { diskusi }\end{array}$ & $\begin{array}{l}\text { ketepatan analis } \\
\text { is dalam } \\
\text { menjawab } \\
\text { kerapian sajian, } \\
\text { kemampuan ko }\end{array}$ & 5 \\
\hline
\end{tabular}




\begin{tabular}{|c|c|c|c|c|c|c|c|}
\hline & & $13 / 2007)$ & & & $\begin{array}{l}\text { kelompok, } \\
\text { draft } \\
\text { proposal }\end{array}$ & $\begin{array}{l}\text { munikasi } \\
\text { Sumbar kutipan } \\
\text { acuan }\end{array}$ & \\
\hline 14 & $\begin{array}{l}\text { Mahasiswa mampu } \\
\text { menganalisis } \\
\text { Permendiknas } \\
\text { 13/2007 }\end{array}$ & $\begin{array}{l}\text { Profesionali } \\
\text { sme } \\
\text { Pengawas } \\
\text { Pendidikan } \\
\text { (Permendik } \\
\text { nas } \\
12 / 2007 \text { ) }\end{array}$ & $\begin{array}{l}\text { Ceramah } \\
\text { diskusi dan } \\
\text { Tanya } \\
\text { jawab }\end{array}$ & $\begin{array}{l}100 \\
\text { menit }\end{array}$ & $\begin{array}{l}\text { Tes esay } \\
\text { dan } \\
\text { rangkuma } \\
\text { n hasil } \\
\text { diskusi } \\
\text { kelompok, } \\
\text { draft } \\
\text { proposal }\end{array}$ & $\begin{array}{l}\text { ketepatan analis } \\
\text { is dalam } \\
\text { menjawab } \\
\text { kerapian sajian, } \\
\text { kemampuan ko } \\
\text { munikasi } \\
\text { Sumbar kutipan } \\
\text { acuan }\end{array}$ & 5 \\
\hline 15 & $\begin{array}{l}\text { Mahasiswa } \\
\text { memiliki } \\
\text { pemahaman yang } \\
\text { komprehensif } \\
\text { tentang PUUP }\end{array}$ & $\begin{array}{l}\text { Refleksi } \\
\text { Akhir }\end{array}$ & $\begin{array}{l}\text { Ceramah } \\
\text { diskusi dan } \\
\text { Tanya } \\
\text { jawab }\end{array}$ & $\begin{array}{l}100 \\
\text { menit }\end{array}$ & $\begin{array}{l}\text { Tes esay } \\
\text { dan } \\
\text { rangkuma } \\
\text { n hasil } \\
\text { diskusi } \\
\text { kelompok, } \\
\text { draft } \\
\text { proposal }\end{array}$ & $\begin{array}{l}\text { ketepatan analis } \\
\text { is dalam } \\
\text { menjawab } \\
\text { kerapian sajian, } \\
\text { kemampuan ko } \\
\text { munikasi } \\
\text { Sumbar kutipan } \\
\text { acuan }\end{array}$ & 5 \\
\hline 16 & UAS & & & & & & 30 \\
\hline
\end{tabular}




\section{BAB I}

\section{Hakekat Manusia sebagai Individu dan Kelompok}

\section{A. Pokok Bahasan}

Hakekat Manusia sebagai Individu dan Kelompok

\section{B. Kompetensi yang akan dicapai}

1. memahami hakekat manusia sebagai individu dan kelompok dalam kehidupan

2. memahami proses pembentukan kelompok

3. mengetahui dimensi hubungan antarkelompok

\section{Petunjuk belajar}

1. membaca basmalah sebelum memulainya

2. membaca materi dan penjelasan-penjelasan didalamnya dengan seksama

3. perhatikan penjelasan-penjelasan yang disampaikan

4. kerjakan soal-soal yang ada dengan baik dan benar

\section{Isi materi Pembelajaran}

\section{Proses Individu Menjadi Kelompok}

Manusia sebagai makhluk individu memiliki unsur jasmani dan rohani, unsur fisik dan psikis, unsur raga dan jiwa. Seorang individu adalah perpaduan antara faktor genotype dan fenotipe. Faktor genotype adalah faktor yang dibawa individu sejak lahir, ia merupakan faktor keturunan dibawa individu sejak lahir. Kepribadian adalah keseluruhan perilaku individu yang merupakan hasil interaksi antara potensi-potensi biopsikofisikal (fisik dan psikis) yang terbawa sejak lahir dengan rangkaian situasi lingkungan, yang terungkap pada tindakan dan perbuatan serta reaksi mental psikologisnya, jika mendapat rangsangan dari lingkungan.

Cooley memberi nama looking glass-self untuk melihat bahwa seseorang dipengaruhi oleh orang lain. Cooley berpendapat bahwa looking glass-self terbentuk melalui 3 tahap. Pada tahap pertama seseorang mempunyai persepsi mengenai pandangan orang lain terhadapnya. Pada tahapan berikutnya seseorang mempunya persepsi mengenai penilaian orang lain terhadap penampilannya. Pada tahap ketiga seseorang mempunyai 
perasaan terhadap apa yang dirasakannya sebagai penilaian orang lain terhadapnya itu.

Dalam sebuah massa manusia cenderung menyingkirkan individualitasnya karena tingka lakuknya adalah hampir identik dengan tingkah laku massa bersangkutan. Dalam hubungan ini dapat dicirikan, apabila manusia dalam tindakan-tindakannya menjurus kepada kepentingan pribadi maka disebut manusia sebagai makhluk individu, sebaliknya apabila tindakan-tindakannya merupakan hubungan dengan manusia-manusia lainnya, maka manusia itu dikatakan mahkluk sosial. Pengalaman menunjukan bahwa jika seseorang pengabdiannya kepada diri sendiri besar, maka pengabdiannya kepada masyarakat kecil.

Sebaliknya jika seseorang pengabdianya kepada diri sendiri kecil, maka pengabdiannya kepada masyarakat besar. Dengan demikian dapatlah dikatakan bahwa yang dapat meningkatkan ciri-ciri individualitas pada seseorang sampai ia adalah dirinya sendiri, disebut sebagai proses individualias, atau kadang-kadang juga diberi nama proses aktualisasi diri.

Dalam perkembangannya, manusia sebagai mahkluk individu tidak bermakna kesatuan jiwa dan raga, tetapi akan menjadi yang khas dengan corak kepribadiannya.

Pandangan yang mengembangkan pemikiran bahwa manusia pada dasarnya adalah individu yang bebas dan merdeka adalah paham individualisme. Paham individualisme menekankan kesususan, martabat, hak, dan kebebasan orang perorang. Manusia sebagai individu yang bebas dan merdeka tidak terikat apapun dengan masyarakat ataupun negara. Manusia bisa berkembang dan sejahtera hidupnya serta berlanjut apabila dapat bekerja secara bebas dan berbuat apa saja untuk memperbaiki dirinya sendiri.

Paham yang mengembangkan pentingnya aspek kehidupan sosial kehidupan manusia adalah sosialisme. Sosialisme memberikan nilai lebih pada manusia sebagai sebagai makhluk sosial. Sosialisme merupakan reaksi atas sistem liberalisme yang dilahirkan oleh paham individualisme.

Salah satu peranan dikaitkan dengan sosialisasi oleh teori George Herbert Mead. Dalam teorinya yang diuraikan dalam buku Mind, Self, and 
Socienty (1972), Mead menguraikan tahap-tahap pengembangan secara bertahap melalui beberapa tahap-tahap Play Stage, tahap Game Stage, dan tahap Generalized Other.

Menurut mead setiap anggota baru masyarakat harus mempelajari peranan-peranan yang ada dalam masyarakat. Sosialisasi adalah suatu proses dimana didalamnya terjadi pengambilan peranan yang harus dijalankannya serta peranan yang harus dijalankan orang lain. Melalui penguasaan peranan yang ada dalam masyarakat ini seseorang dapat berinteraksi dengan orang lain. Menurut Mead tahap-tahapan itu adalah:

a. Play Stage, seseorang anak kecil mulai belajar mengambil peranan orangorangg yang ada di sekitarnya. Ia mulai menirukan peranan yang dijalankan oleh orang tuanya atau peranan orang dewasa lain dengan siapa ia sering berinteraksi.

b. Game Stage, seorang anak tidak hanya telah mengetahui peranan yang harus dijalankannya, tetapi telah pula mengetahui peranan yang harus dijalankannya oleh orang lain dengan siapa ia berinteraksi.

c. Generalized Other, pada tahap awal sosialisasi, interaksi seorang anak biasanya terbatas pada sejumlah kecil orang lain biasanya snggota keluarga, terutama ayah dan ibu. Oleh Mead orang-orang yang penting dalam proses sosialisasi ini dinamakan significant other.

Pada tahap ketiga sosialisasi seseorang dianggap telah mampu mengamil peranan-peranan yang dijalankan orang lain dalam masyarakat mampu mengambil peranan Generalized Other. Ia telah mampu brinterksi dengan orang lain dalam masyarakat karena telah memahami peranannya sendiri serta peranan orang lain dengan siapa ia berinteraksi.

Selain penguasaan peran indidvidu dalam bersosial ada pula alasanalasan yang menyatakan manusia sebagai makhluk sosial, yaitu:

a. Manusia tunduk pada norma sosial, aturan

b. Perilaku manusia mengharapkan penilaian dari orang lain

c. Manusia memiliki kebutuhan untuk berinteraksi dengan orang lain

d. Potensi manusia akan berkembang bila ia hidup di tengah-tengah manusia 
Jadi, dapat disimpulkan bahwa proses individu menjadi kelompok yaitu karena tunduk pada norma sosial, mengharap penilaian dari orang lain, manusia memiliki kebutuhan untuk berinteraksi, dan meningkatkan potensi atau skill yang dimiliki. Dengan diawali penguasaan peran.

\section{Nilai dan Norma Sosial}

Berbagai kelompok sosial tumbuh seiring dengan kebutuhan manusia untuk saling berinteraksi. Dalam berbagai kelompok sosial ini, manusia membutuhkan nilai dan norma pengaturannya, karena kunci untuk menertibkan masyarakat adalah dengan nilai dan norma.

Dalam ilmu sosiologi, nilai mengandung pengertian yang lebih luas. Niali (value) dalam konteks sosiologi berhubungan dengan pertanyaan 'mengapa?' dan 'bagaimana?' suatu kondisi dapat terjadi dimasyarakat.

Nilai adalah konsepsi abstrak dalam diri manusia mengenai apa yang baik atau yang buruk. Niali juga berfungsi sebagai landasan, alasan, atau motivasi dalam segala tingkah laku dan perbuatan sesorang.

Niali mencerminkan kualitas pilihan tindakan dan pandangan hidup seseorang atau masyarakat. Prof. Dr. Notonegoro membagi nilai sosial menjadi tiga, yaitu:

1. Nilai material, yaitu segala sesuatu yang berguna bagi unsur fisik manusia.

2. Nilai vital, yaitu segala sesuatu yang berguna bagi manusia untuk mengadakan kegiatan atau aktivitas.

3. Nilai kehormatan, yaitu segala sesuatu yang berguna bagi batin (rohani).

a. Nilai kebenaran yang bersumber pada akal

b. Nilai keindahan (niali estetis)

c. Nilai kebaikan atau nilai moral yang bersumber pada kodrat

d. Nilai religius

Berikut Norma-norma untuk bertingkah laku bagi manusia di kelompoknya.

a. Norma agama atau religi, yaitu norma yang bersumber dari Tuhan yang diperuntukkan bagi umat-Nya. Norma agama berisi perintah agar dipatuhi dan larangan agar dijauhi umat beragama. Norma agama ada dalam ajaran-ajaran agama. 
b. Norma kesusilaan atau moral, yaitu norma yang bersumber dari hati nurani manusia untuk mengajak kepada kebaikan dan menjauhi keburukan. Norma moral bertujuan agar manusia berbuat baik secara moral. Orang berkelakuan baik adalah orang yang bermoral, sedangkan orang yang berkelakuan buruk adalah orang tidak bermoral atau amoral.

c. Norma kesopanan atau adat adalah norma yang bersumber dari masyarakat dan berlaku terbatas pada lingkungan masyarakat yang bersangkutan. Norma ini di maksudkan untuk menciptakan keharmonisan hubungan antarsesama.

d. Norma hukum, yaitu norma yang dibuat masyarakat secara remi (negara) yang pemberlakuannya dapat dipaksakan. Norma hukum yang brsifat tertulis.

Selain itu, norma dapat dibedakan pula menjadi empat macam berdasarkan kekuatan berlakunya dimasyarakat. Ada norma yang daya ikatnya sangat kuat, sedang, dan ada pula norma yang daya ikatnya sangat lemah.

Keempat jenis tersebut adalah cara (usage), kebiasaan (folkways), tata kelakuan (mores), dan adat istiadat (costum).

\section{Cara (usage)}

Cara adalah bentuk kegiatan manusia yang daya ikatnya sangat lemah. Norma ini lebih menonjol dalam hubungn antarindividu atau perorangan. Pelanggaran terhadap norma ini tidak mengakibatkan hukuman yang berat, tetapi sekedar celaan. Contohnya cara makan, ada yang makan sambil berdiri dan ada yang makan sambil duduk. Cara makan sambil duduk dianggap lebih panas dibandingkan cara makan sambil bediri.

2. Kebiasaan (falkways)

Kebiasaan adalah kegiatan atau perbuatan yang di ulang-ulang dalam bentuk yang sama oleh orang banyak kerana disukai. Norma ini lebih kuat daya ikatnya dari pada norma cara. Contohnya, kebiasaan salam bila bertemu.

3. Tata kelakuan (mores) 
Tata kelakuan adalah kebiasaan yang di anggap sebagai norma pengatur. Sifat norma ini disatu sisi sebagai pemaksa suatu perbuatan dan disisi lain sebagai suatu larangan. Dengan demikian, tata kelakuan dapat menjadi acuan agar masyarakat menyusuaikan diri dengan kelakuan yang ada serta meninggalkan perbuatan yang tidak sesui dengan tata kelakuan.

4. Adat istiadat (custom)

Adat istiadat adalah kelakuan yang telah menyatu kuat dalam pola-pola perilaku sebuah masyarakat.

\section{Problematika Manusia Dalam Kelompok}

Sebagai mahluk hidup yang berada di muka bumi ini keberadaan manusia adalah sebagai mahluk individu dan mahluk sosial, dalam asrti manusia senantiasa tergantung dan atau berinteraksi dengan sesamanya.

Dengan demikian, maka dalam kehidupan lingkungan sosial manusia senantiasa terkait dengan interaksi antara individu manusia, interaksi antar kelompok, kehidupan sosial manusia dengan lingkungan hidup dan alam sekitarnya, berbagai proses sosial dan interaksi sosial, dan berbagai hal yang timbul akibat aktivitas manusia seperti perubahan sosial.

Secara sosial sebenarnya manusia merupakan mahluk individu dan sosial yang mempunyai kesempatan yang sama dalam berbagai hidup dan kehidupan dalam masyarakat. Artinya setiap individu manusia memiliki hak, kewajiban dan kesempatan yang sama dalam menguasai sesuatu, misalnya bersekolah, melakukan pekerjaan, bertanggung jawab dalam keluarga serta berbagai aktivitas ekonomi, politik dan bahkan beragama.

Namun demikian, kenyataannya setiap individu tidak dapat menguasai atau mempunyai kesempatan yang sama. Akibatnya, masingmasing individu mempunyai peran dan kedudukan yang tidak sama atau berbeda.

Banyak faktor yang menyebabkan itu bisa terjadi, misalnya kondisi ekonomi (ada si miskin dan si kaya), sosial (warga biasa dengan pak RT, dll), politik (aktivis partai dengan rakyat biasa), budaya (jago tari daerah dengan tidak) bahkan individu atau sekelompok manusia itu sendiri. Dengan kata 
lain, stratifikasi sosial mulai muncul dan tampak dalam kehidupan masyarakat tersebut.

Interaksi sosial hanya dapat berlangsung antara pihak-pihak apabila terjadi reaksi dari kedua belah pihak. Interaksi sosial tidak mungkin terjadi apabila manusia mengadakan hubungan yang langsung dengan sesuatu yang sama sekali tidak berpengaruh terhadap sistem sarafnya sebagai akibat hubungan yang dimaksud.

Ciri-ciri interaksi sosial adalah sebagai berikut.

1. Pelakunya lebih dari satu orang

2. Adanya komunikasi antar pelaku melalui kontak sosial

3. Mempunyai maksud dan tujuan, terlepas dari sama atau tidaknya tujuan tersebiut dengan yang diperkirakan pelaku.

4. Ada dimensi waktu yang akan menentukan sikap aksi yang sedang berlangsung.

Syarat terjadinya interaksi sosial adalah adanya kontak sosial (social contact) dan komunikasi. Kontak sosial berasal dari kata con atau cun yang artinya bersama-sama, dan tango yang artinya menyentuh. Namun, kontak sosial tidak hanya secara harfiah bersentuhan badan, tetapi bisa lewat bicara, melalui telepon, telegram, surat radio, dan sebagainya.

Kontak dapat bersifat primer dan sekunder. Kontak primer terjadi apabila ada kontak langsung dengan cara berbicara, jabat tangan, tersenyum, dan sebagainya. Kontak sekunder terjadi dengan perantara. Kontak sekunder langsung, misalnya melalui telepon, radio, TV, dan sebagainya.

Kontak sosial dapat terjadi dalam tiga bentuk, yaitu

1. Kontak antar individu, misalnya seorang siswa baru mempelajari tata tertib dan budaya sekolah

2. Kontak antarindividu, dengan suatu kelompok, misalnya seorang guru mengajar di suatu kelas tentang suatu poko bahasan.

3. Kontak antarkelompok dengan kelompok lain, misalnya class meeting antarkelas. 
Komunikasi adalah proses memberikan tafsiran pada perilaku orang lain yang berwujud pembicaraan, gerak-gerik badaniah atau sikap, atau perasaan-perasaan apa yang ingin disampaikan orang tersebut.

Dengan tafsiran pada orang lain, seseorang memberi reaksi berupa tindakan terhadap maksud orang lain tersebut. Misalnya, jika anda melambaikan tangan dipinggir jalan atau halte bus maka salah satu bus yang lewat pasti akan berhenti, jadi, komunikasi merupakan proses saling memberi penafsiran terhadap tindakan atau perilaku orang lain.

Berlangsungnya interaksi sosial didasarkan tas berbagai faktor, antara lain faktor imitasi, sugesti, identifikasi, simpati, motivasi, dan empati, imitasi adalah proses atau tindakan seseorang untuk meniru orang lain baik sikap, perbuatan, penampilan, dan gaya hidup.

Sugeti adalah rangsangan, pengaruh, atau stimulus yang diberikan individu kepada individu lain sehingga orang yang diberi sugesti itu melaksanakan apa yang disegestikan tanpa sikap kritis dan rasional, identifikasi adalah upaya yang dilakukan individu untuk menjadi sama (identik) dengan individu yang ditirunya.

Proses identifikasi erat kaitannya dengan imitasi. Simpati adala prose kejiwaan seseorang individu yang merasa tertarik dengan individu atau kelompok karena sikap, penampilan, atau perbuatannya.

Motivasi merupakan dorongan, rangsangan, pengaruh, atau stimulasi yang diberikan individu kepada individu lain sehingga orang yang diberi motivasi melaksankannya dengan secara kritis, rasional, dan tanggung jawab.

Empati adalah proses kejiwaan seorang individu untuk larut dalam perasaan orang lain baik suka maupun duka.

Seperti telah dikemukakan diatas, bentuk-bentuk interaksi sosial adalah akomodasi, kerja sama, persaingan, dan pertikaian. Secara luas, dapat dikatakan ada interaksi sosial yang sifatnya positif, yaitu mengarah pada kerjasama antrindividu atau antarkelompok.

Interaksi sosial yng dimaksud interaksi soial yang bersifat asosiatif. Adapula interaksi sosial yang mengarah pada bentuk-bentuk pertikaian tau 
konflik. Interaksi sosial dimasud disebut dengan interaksi sosial yang bersifat disosiatif.

Interaksi sosial yang bersifat asosiatif, seperti kerja sama, akomodasi, asimilasi, dan akulturasi. Interaksi sosial yang bersifat disasosiatif mencakup persaingan, kontroversi, dn permusuhan.

Dengn demikian, dinamika interaksi sosial yang terjadi dala kehidupan sosial dapt beragam. Dilihat dari jenisnya ada interaksi antarindividu, interaksi individu dengan kelompok, dan interaksi antar kelompok.

Dilihat dari faktor penyebabnya, ada interaksi yang disebabkan oleh faktor imitasi, sugesti, identifikasi, simpati, motivsi, dan empati. Ada interaksi yang berbentuk pertentangan. Sedangkan jika dilihat dari sifat interaksinya, da interaksi yang asosiatif, interaksi disasosiatif.

Interaksi sosial merupakan kunci dri semua kehidupan sosial, karena tanpa interaksi sosial tidak mungkin ada kehidupan bersama. Manusia sebagai mkhluk sosial pastilah melkukan intraksi sosial dalam rngka hidup bersama.

\section{Cara-cara Pengendalian Sosial}

Dalam hidup berkelompok terdapat banyak problematika yang terjadi, dan pasti harus diselesaikan. Berikut cara-cara pengendalian sosial:

a. Cara pengendalian secara lisan, simbolik, dan kekerasan

Cara pengendalian melalui lisan dan simbolik disebut juga cara pengendalian sosial persuasif. Cara ini menekankan pada usaha untuk menhajak atau membimbing anggota masyarakat agar dapat bertindak sesuai dengan aturan-aturan yang berlaku.

Pengendalian sosial secara lisan dilakukan dengan mengajak orang menaati peraturan dengan menggunakan bahasa lisan (verbal).

Sedangkan pengendalian sosial secara simbolik dilakukan melalui tulisan, spanduk, dan iklan layanan masyarakat.

Cara pengendalian sosial melalui kekerasan sering disebut juga pengendalian sosial koersif. Cara menekan tindakan atau ancaman yang 
menggunakan kekuatan fisik. Tujuannya agar si pelaku jera dan tidak melakukannya.

b. Cara pengen dalian sosial melalui imbalan dan hukuman

Cara pengendalian sosial melalui imbalan cenderung bersifat preventif (mengalihkan)

Cara pengendalian sosial melalui hukuman cenderung bersifat represif. Cara ini bertujuan untuk memulihkan keadaan seperti sebelum terjadi pelanggaran.

c. Cara pengendalian sosial formal dan informal

Csra pengendalian sosial formal menurut Paul Horton dan Chester Hunt adalah cara pengendalian sosial oleh lembaga-lembaga resmi yang memiliki peraturan-peraturan resmi. Peraturan-peraturan lembaga ini umumnya tertulis dan sudah distandarkan.

Cara pengendalian informal adalag cara pengendalian sosial yang dialkukan oleh kelompok kecil, akrab, bersifat tidak resmi, dan tidak memiliki aturan resmi yang tertulis.

Hukuman teman secara spontan, seperti mangejek, menyindir, menyebarkan desas-desus, dan memberikan terguran.

d. Cara pengendalian sosial memlaui sosialisasi

Menurut Erich Fomm, apabila suatu masyarakat ingin berfungsi efektif maka para anggota harus berperilaku sesuai dengan nilai dan norma sosial yang mengatur pola hidup masyarakat tersebut.

Dalam sosialisasi, individu dikenadalikan sehingga tidak melakukan perilaku menyimpang. Menurut Fomm, sosialisasi membentuk kebiasaan, keinginsn, dan adat istiadat kita. Melalui sosialisasi, seseorang menginteralisasikan norma dan nilai.

e. Cara pengendalian sosial melalui tekanan sosial

Richard Lapiere melihat pengendalian sosial sebagai proses yang lahir dari kebutuhan individu agar diterima ke dalam kelompok.

Para ahli psikologi sosial seperti Revard menghasilkan penelitian yang menyatakan bahwa seseorang cenderung mengekspresikan pernyataan pribadinya seirama atau sesuai dengan pandangan kelompok. 


\section{LATIHAN}

\section{Pilihan Ganda}

1. Norma sosial dapat diurutkan dari yang lemah sampai yang kuat berdasarkan kekuatan mengikatnya seperti tercermin pada hubungan...
A. Usage-folkways,custom-mores
B. Custom-usage-folkways-mores
C. Mores-custom-usage-folways
D. Usage-folkways-mores-custom
E. Custom-usage-mores-folways

2. Menurut Charles Horton Cooley, pembentukan diri seseorang terladi melalui looking-glass self. Dalam proses tersebut, penanda terbentuknya diri adalah...
A. Peniruan peran yang dijalankan oleh orangtuanya atau orang yang oaling sering berinteraksi dengannya (significant others)
B. Kemampuan pengambilan orang lain secara lugas
C. kesadaran akan peran yang ia jalankan dan peran yang dijalankan orang lain
D. kemampuan menjadi diri sendiri
E. kegagalan dalam menyesuaikan diri

3. masyarakat majemuk sangat rentan terhadap konflik sosial, terutama masyarakat majemuk dengan ciri-ciri adanya....
A. fragmentasi sosial
B. kompetisi seimbang
C. minoritas dominan
D. mayoritas dominan
E. kompetisi tidak seimbang

4. perilaku menyimpang adalah tindakan pelanggaran yang dilakukan individu atau kelompok terhadap.....
A. keluarga
B. Nilai
C. Komunitas
D. Klien 

E. Tuhan

5. Prasangka yang tidak didasari pada pengetahuan, pengalaman, dan bukti yang memadai tentang seseorang dari daerah atau suku tertentu disebut....
A. Prmordialisme
B. Stereotip
C. Prejudice
D. Etnosentris
E. Feodal

6. Penggolongan penduduk atas dasar perbedaan ras, agama, jenis kelamin, profesi, suku bangsa, dan sebaginya merupakan konsep dari...
A. Strstifiksi sosial
B. Kelas sosial
C. Tingkatan sosial
D. DEiferensiasi sosial
E. Mobilitas sosial

7. Contoh perilaku individu dalam interaksi sosial yang membuat individu tersebut menjadi bagian dan terikat dengan lemabaga sosial tersebut....
A. Mengikuti diskusi kelas
B. Menjadi anggota Karang Taruna
C. Melakukan rekreasi di akhir pekan
D. Mengenal tarian tradisional daerah lain
E. Mematuhi peraturan lalu lintas

8. Perbedaan peranan antara laki-laki dan perempuan yang dikonstruksi secara sosial disebut...
A. Kodrat
B. Emansipasi
C. Gender
D. Diskriminatif
E. Feminis

9. Hubungan sosial timabl-balik yang saling memengaruhi disebut....
A. Kausal
B. Simultan 

C. Resiprokal
D. Periodeik
E. Diadik

10. Tahap sosialisasi dimana seorang individu melakukan proses belajar tidak serta merta meniru tetapi lebih pada pola menyesuaikan diri menurut G. H. Meod berada pada tahap...
A. Persiapan
B. Play stage
C. Game stag
D. Dinal stage
E. Generalized other

\section{Essay}

1. Sebutkan fungsi dari nilai sosial!

2. Apa yang dimaksud norma susila?

3. Apa fungsi dari pengendalian sosial?

4. Apa yang dimaksuk represif dalam pengendalian sosial?

5. Sebutkan unsur-unsur sosial dalam struktur sosial! 


\section{JAWABAN}

\section{Pilihan Ganda}

1. Berikut ini adalah urutan norma sosial mulai dari yang paling lemah sampa yang paling kuat:
a. Usage atau tata cara
b. Folkways atau kebiasaan
c. Mores atau tata kelakuan
d. Custom atau adat istiadat
e. Law atau hukum

Jawaban: D

2. Menurut Charles Horotn Cooley, pembentukan diri seseorang terjadi dan dapat dilakukan melalui looking-glass self. Looking-glass self adalah pembentukan diri seseorang atau kemampuan untuk menjadi diri sendiri.

Jawaban: D

3. a. fragmentasi sosial adalah perkembangan sosial dimana bertambah lagi kelompok sosial

b. kompetisi seimbang, adalah suatu kondisi dimana sebuah kompetisi atau persaingan seimbang antara kaum mayoritas dan minoritas

c. minoritas dominan adalah suatu kondisi dimana kaum minoritas lebih dominan bersuara dan berkontribusi

d. mayoritas dominan adalah suatu kondisi dimana kaum mayoritas yang banyak bersuaru dan berkomtribusi

e. kompetisi tidak seimbang, adalah suatu kondisi dimana persaingan anatar kaum mayoritas dan minoritas tidak seimbang dan terjadi banyak problematika diantara masyarakat

Jawaban; E

4. Nilai adalah konsepsi abstrak dalam diri manusia mengenai apa yang baik atau yang buruk. Niali juga berfungsi sebagai landasan, alasan, atau motivasi dalam segala tingkah laku dan perbuatan sesorang. 
Niali mencerminkan kualitas pilihan tindakan dan pandangan hidup seseorang atau masyarakat.

Jawaban: B

5. a. Primordialisme adalah pandangan atau paham yang menunjukkan ikstan berpegang teguh pada hal-hal yang sejak dulu sudah melekat pada diri sendiri

b. Stereotip adalah prasangka

c. Prejudice adalah sikap permusuhan dengan sebab kelompok tertentu memilikki sikap tak menyenangkan

d. Etnosentris adalah menilai kebudayaan masyarakat lain dengan ukuran-ukuran yang berlalu dimasyarakat

e. Feodal adalah bangsawan

Jawaban: B

6. a. Diferensiasi sosial, yaitu penggolongan masyarakat secara horizontal berdasarkan ras, agama, jenis kelamin, profesi, dan suku bangsa.

b. strastifikasi sosial, yaitu penggolongan masyarakat secara vertikal berdasarkan kekayaan, pendidikan, kekuasaan, dan keturunan.

Jawaban: D

7. Salah satu ciri lembaga sosial yang brhubungan dengan perilaku individu yang terlibat di dalamnya, yaiatu adanya praturan tertulis atau tidak tertulis. Menurut Gilling, ciri-ciri umum lembaga sosial adalah:

a. Lembaga sosial terdiri atas adat istiadat, tata kelakuan, kebiasaan-kebiasaan, dan unsur-unsur kebudayaan lainnya.

b. Sistem-sistem kepercayaan dan aneka tindakan, baru akan menjadi bagian lembaga kemasyarakatan setelah melewati waktu yang relatif lama.

c. Lembaga memiliki satua atau lebih tujuan tertentu

d. Mempunyai alat-alat perlengkapan yang dipergunakan untuk mencapai tujuan lembaga yang bersangkutan 
e. Mempunyai tradisi trtulis dan tidak tertulis yang merumuskan tujuannya, tata tertib yang brlaku, dan lain-lain. Tradisi tersebut merupakan dasar bagi lembaga itu.

Jawaban; E

8. Dalam setiap peranan anatara laki-laki dan perempuan sangat berbeda, semua itu hanya hasil kontruksi yang dibuat oleh masyarakat dengan kesepakatan bersama, yaitu:

a. Gender adalah perbedaan antara laki-laki dan perempuan berdasarkan pembagian tugas secara sosial (kontruksi)

b. Jenis kelamin adalah perbedaan anatara laki-laki dan perempuan secara biologis

c. Feminisme merupakan suatu cara pandamg baru dan berbeda mengenai diri kita sendiri dan masyarakat kita, lebih pada kaum perempuan

Jawab: C

9. Resiprokal adalah hubungan timbal balik yang memengaruhi antara individu dengan individu, individu dengan kelompok, atau kelompok dengan kelompok

Jawaban: C

10. Menurut G. H. Mead, proses sosialisasi terdiri dari beberapa tahap. Proses sosialisasi dimana seorang individu sudah belajar menyesuaikan diri atau mulai memiliki kemampuan dalam menempatkan diri terdapat pada tahap gamestage (siap bertindak) Jawaaban: C

\section{Essay}

1. Fungsi dari nilai sosial adalah:

a. Menyumbangkan seperangkat alat untuk menetapkan harga sosial dalam masyarakat

b. Mengarahkan masyarakat untuk berpikir dan bertingkah laku

c. Penentu akhir bagi manusia dalam memenuhi peran sosialnya

d. Menjadi alat solidaritsa dikalangan kelompok masyarakat

e. Menjadi pengawas kontrol manusia 
2. Norma susila merupakan perturan sosial yang berasal dari hati nurani manusia yang menghasilkan akhlak sehingga ia dapat membedakan yang baik dan yang buruk.

3. Fungsi dari pengendalian sosial adalah:

a. Mempertebal keyakinan masyarakat terhadap norma sosial

b. Mengembangkan rasa malu dan rasa takut

c. Menciptakan sistem hukum

d. Memberikan imbalan kepada warga masyarakat yang menaati norma

4. Represif, yaitu berbagai upaya pengendalian sosial yang dilakukan untuk mengembalikan kedamaian dan ketrtiban masyarakay yang pernah terganggu, dan dilakukan dalam benttuk pemberian sanksi kepada pelaku yang menyimpang dari norma yang berlaku.

5. Unsur-unsur sosial menurut Soerjono Soekanto, yaitu:

1. Kelompok sosila

2. Kebudayaan

3. Lembaga sosial

4. Stratifikasi sosial

5. Kekuasaan dan wewenanang 


\section{BAB II}

\section{Konsep Perundang-Undangan Pendidikan}

\section{A. Pokok Bahasan;}

Konsep Perundang-Undangan Pendidikan.

\section{B. Kompetensi yang akan dicapai}

1. Pamaham konsep perturan dalam kehidupan,

2. Pemahaman tentang Peraturan tertulis dan peraturan tidak tertulis,

3. Paham landasan yang digunakan dalam pembentukan perturan Perundangan,

\section{Petunjuk belajar}

1. Baca Do'a sebelum belajar,

2. Pahami dengan seksama setiap penjelasan dalam bagian materi,

3. Perhatikan penjelasan dosen pada saat dosen sedang menerangkan,

4. Buat rangkuman,

5. Kerjakan dengan benar soal-soal latihan yan diajukan.

\section{Materi Pembelajaran}

\section{Peraturan Perundangan}

Bagaimana seharusnya seseorang bersikap dan bertindak baik terhadap sesamanya maupun terhadap alam? Perbuatan-perbuatan apa saja yang dapat dilakukan oleh seseorang, dan perbuatan-perbuatan apa saja yang tidak boleh dilakukan oleh seseorang dalam kehidupan bermasyarakat dan berbangsa? Agar dalam bersikap dan bertindak tidak saling merugikan di antara sesama manusia diciptakanlah seperangkat kaidah atau norma atau aturan. Hal ini dikarenakan setiap orang mempunyai keinginan dan kepentingan yang berbeda. Agar kepentingan yang satu dengan yang lainnya tidak saling bertubrukan dibuatkan seperangkat aturan. Jadi yang disebut kaidah adalah seperangkat aturan yang mengatur kehidupan manusia dalam bergaul dengan manusia lainnya.

Peraturan adalah patokan yang dibuat untuk membatasi tingkah laku seseorang dalam suatu lingkup/organisasi tertentu yang jika melanggar akan dikenakan hukuman/sanksi. Dari pernyataan ini bisa kita temukan beberapa poin utama. Yaitu patokan, membatasi, organisasi, dan sanksi jika melanggar. ${ }^{1}$

${ }^{1}$ https://bayuarsadinata.wordpress.com/2015/07/16/peraturan-adalah-2/ (dikutip 12 Mar. 17, 20.46 wib) 
Sebagai bagian dari masyarakat, kita harus dapat melaksanakan berbagai kaidah hidup yang berlaku di lingkungan masyarakat. Ketertiban dan masyarakat tidak dapat dipisahkan satu sama lain, ibarat dua sisi mata uang. Mengapa? Cicero kurang lebih 2000 tahun yang lalu menyatakan: "Ubi societas ibi ius” artinya apabila ada masyarakat pasti ada kaidah (hukum).

Peraturan juga merupakan proteksi atas dampak yang muncul karena budaya, sosial, politis dan lain-lain. Peraturan juga merupakan proteksi atas dampak yang muncul karena budaya, sosial, politis, dan lain-lain. Kaidah (peraturan) yang berlaku dalam suatu masyarakat mencerminkan corak dan sifat masyarakat yang bersangkutan. Peraturan muncul sebagai hasil dari kesepakatan diantara beberapa orang/masyarakat/komunitas yang berinteraksi untuk mengatur interaksi tersebut. ${ }^{2}$

Pusat Informasi Hukum Indonesia. Pasal 1 butir 2 UU Nomor 10 Tahun 2004 tentang Pembentukan Peraturan Perundang-Undangan menyatakan bahwa yang dimaksud dengan Peraturan Perundang-undangan adalah peraturan tertulis yang dibentuk oleh lembaga negara atau pejabat yang berwenang dan mengikat secara umum. $^{3}$

Hukum/Law merupakan penomena/gejala kemasyarakatan/penomena sosial, dimana masyarakat ada maka hukum ada. Peraturan terbentuk karena kebutuhan untuk mengatur kehidupan dalam bermasyarakat/berinteraksi. Bentuk hukum ada dua yaitu, tertulis dan tidak tertulis. Contoh peraturan tertulis undang-undang, peraturan pemerintah, peraturan presiden, peraturan daerah dan sebagainya. Contoh peraturan tidak tertulis adalah hukum adat, adat istiadat, dan kebiasaan-kebiasaan yang dilaksanakan dalam praktik penyelenggaraan negara atau konvensi. Peraturan yang tertulis memiliki ciri-ciri sebagai berikut:

1. Keputusan yang dikeluarkan oleh yang berwewenang,

2. Isinya mengikat secara umum, tidak hanya mengikat orang tertentu, dan

3. Bersifat abstrak (mengatur yang belum terjadi).

\footnotetext{
${ }^{2}$ http://file.upi.edu/Direktori/FIP/JUR._ADMINISTRASI_PENDIDIKAN/197203211999031ASEP SURYANA/BAHAN AJAR PERUNDANG UNDANGAN PENDIDIKAN.pdf\#page=19\&zoom=auto,107,842

${ }^{3}$ https://portal.mahkamahkonstitusi.go.id/eLaw/peraturan perundangan.php (dikutip 12 Mar. 17, 20.46 wib)
} 
Ferry Edwar dan Fockema Andreae menyatakan, bahwa perundang-undangan (legislation, wetgeving atau gezetgebung) mempunyai dua pengertian, pertama perundang-undangan merupakan proses pembentukan atau proses membentuk peraturan perundang-undangan negara, baik di tingkat pusat maupun di tingkat daerah. Kedua perundang-undangan adalah segala peraturan negara yang merupakan hasil pembentukan peraturan-peraturan, baik tingkat pusat maupun di tingkat daerah. ${ }^{4}$

Bentuk-bentuk aturan pengaturan kehidupan dalam bermasyarakat tersebut dapat berupa hasil yang tuangkan dalam bentuk tertulis hitam di atas putih, atau juga tidak tertulis atau konvensi yang disepakatai bersama.

J.P. Glastra van Loan menyatakan, dalam menjalankan peranannya, hukum mempunyai fungsi :

1. Menertibkan masyarakat dan pengaturan pergaulan hidup;

2. Menyelesaikan pertikaian;

3. Memelihara dan mempertahankan tata tertib dan aturan, jika perlu dengan kekerasan;

4. Mengubah tata tertib dan aturan-aturan dalam rangka penyesuaian dengan kebutuhan masyarakat;

5. Memenuhi tuntutan keadilan dan kepastian hukum dengan cara merealisasikan fungsi hukum sebagaimana disebutkan di atas.

Tujuan dari peraturan adalah mengarah kepada ketertiban dan keharmonisan dalam hidup dan kehidupan bermasyarakat. Adanya interaksi menyebabkan banyaknya kepentingan dari masing-masing individu tersebut.

Hukum/peraturan yang dilahirkan dimaksudkan agar interaksi tersebut dapat berjalan dengan tertib dan harmonis, dimana semua kepentingan dapat terwadahi. Landasan hukum yang mengatur/landasan yuridis suatu organisasi sebagai normanorma dalam berperilaku disebut perundangan (dalam bidang pendidikan disebut perundangan pendidikan). Produk-produk hukum : UU, PP, Kep.Res, Kep.Men, dll.

\footnotetext{
4http://udmorvansarta.blogspot.co.id/2015/08/konsep-dan-hakekat-perundangundangan.html (dikutip, minggu, 12 Maret 2017, jam 08.03 Wib)
} 
Produk-produk kebijakan tertulis dalam sebuah kehidupan yang besar seperti negara disebut perundangan negara. Bentuk-bentuk dari produk perundangan negara Indonesia dibuat secara bertingkat, dimulai dari hukum tertinggi yaitu UndangUndang sampai kepada masing-masing satuan pimpinan pada tingkat yang paling rendah dalam pemerintahan.

\section{Landasan Pembuatan Perundangan}

Perundang-undangan yang dihasilkan tidak begitu saja dibuat, dalam pembuatannya ada sejumlah komponen yang harus dipenuhi, yaitu menyangkut isi atau substansi dan prosedur penyusunannya. Substansi maupun prosedur tersebut harus mengacu kepada sebuah pedoman dasar sebagai landasan.

Secara utuh landasan yang harus dijadikan sebagai acuan dalam pembentukan perundangan dalam bidang apa juga tidak terkecuali dalam bidang pendidikan. Landasan itu meliputi landasan filosofis, landasan sosiologis, landasan yuridis dan landasan politis. Keempat lanadasan tersebut merupakan satu kesatuan yang utuh. Pemikiran landasan dalam penyusunan perundangan itu meliputi;

\section{FILOSOFIS}

Penyusunan perundangan didasarkan pada etika dan norma kehidupan di Indonesia, meliputi nilai-nilai baik, adil, damai, kebersamaan, kerukunan, perlindungan, dan lain-lain. Dasar falsafah atau pandangan hidup atau ide yang menjadi dasar cita-cita menuangkan hasrat dan kebijaksanaan pemerintah kedalam suatu rancangan (draft) peraturan negara.

2. SOSIOLOGIS

Perundangan menggambarkan keterlibatan masyarakat dalam pembentukan dan pelaksanaan kegiatannya (aspirasi).

3. YURIDIS

Tata urutan peraturan perundangan selalu melihat bagaimana peraturan diatasnya dan hubungan-hubungannya diantaranya, Sehingga tidak menyenggol peraturan diatasnya, disampingnya maupun dibawahnya. Di dalam Negara Republik Indonesia yang berdasarkan atas hukum, maka setiap peraturan perundang-undangan, harus mencantumkan dasar/landasan hukumnya. 
a. Landasan Yuridis Formil, berfungsi memberi kewenangan bagi instansi tertentu untuk membuat peraturan tertentu atau dasar hukum kewenangan.

b. Landasan Yuridis Materiil, berfungsi mengatur materi atau hal-hal tertentu.

4. POLITIS

Garis kebijaksanaan politik yang menjadi dasar selanjutnya bagi kebijaksanaan-kebijaksanaan dan pengarahan ketatalaksanaan pemerintahan negara.

\section{Landasan Hukum Pendidikan}

\section{a). Pengertian}

Secara khusus, pendidikan adalah usaha sadar yang dilakukan oleh keluarga, masyarakat, dan pemerintah, melalui kegiatan bimbingan, pengajaran, dan/atau latihan, yang berlangsung di dalam dan luar sekolah sepanjang hayat, untuk mempersiapkan peserta didik agar dapat memainkan peranan dalam berbagai lingkungan hidup secara tepat di masa yang akan datang (Mudyaharjo, 2008: 3, 11).

Menurut Undang-Undang RI Nomor 2 Tahun 1989 tentang Pendidikan Nasional pasal 1 : "Pendidikan adalah usaha sadar dan terencana untuk mewujudkan suasana belajar dan proses pembelajaran agar peserta didik secara aktif mengembangkan potensi dirinya untuk memiliki kekuatan spiritual keagamaan, pengendalian diri, kepribadian, kecerdasan, akhlak mulia, serta keterampilan yang diperlukan dirinya, masyarakat, bangsa dan negara".

Pendidikan sebagai usaha sadar yang selalu bertolak dari sejumlah landasan serta pengindahan sejumlah asas-asas tertentu. Landasan dan asas tersebut sangat penting, karena pendidikan merupakan pilar utama terhadap perkembangan manusia dan masyarakat bangsa tertentu. Secara umum, pendidikan merupakan segala pengalaman belajar yang berlangsung dalam segala lingkungan dan sepanjang hidup.

Landasan yuridis atau hukum pendidikan dapat diartikan seperangkat konsep peraturan perundang-undangan yang berlaku yang menjadi titik tolak atau acuan (bersifat material, dan bersifat konseptual) dalam rangka praktek pendidikan dan studi pendidikan. Jadi, landasan hukum pendidikan adalah dasar atau fondasi perundang-undangan yang menjadi pijakan dan pegangan dalam pelaksanaan pendidikan di suatu negara. 
Tiap-tiap negara memiliki peraturan perundang-undangan sendiri. Landasan yuridis pendidikan Indonesia juga mempunyai seperangkat peraturan perundangundangan yang menjadi titik tolak sistem pendidikan di Indonesia, yang meliputi :

- Pembukaan UUD 1945

- UUD 1945 sebagai Landasan Yuridis Pendidikan Indonesia.

- Pancasila sebagai Landasan Idiil Sistem Pendidikan Indonesia.

- Ketetapan MPR sebagai Landasan Yuridis Pendidikan Nasional

- Undang-Undang dan Peraturan Pemerintah sebagai Landasan Yuridis Pendidikan Nasional

- Keputusan Presiden sebagai Landasan Yuridis Pelaksanaan Pendidikan Nasional

- Keputusan Menteri sebagai Landasan Yuridis Pelaksanaan Pendidikan Nasional

- Instruksi Menteri sebagai Landasan yuridis Pelaksanaan Pendidikan Nasional

\section{Undang-Undang dan Peraturan Pendidikan}

\section{a. Undang-Undang Pendidikan}

\section{- Pembukaan Undang-Undang Dasar 1945}

Pada Pembukaan UUD 1945 yang menjadi landasan hukum pendidikan terdapat pada Alinea Keempat.

\section{- Pendidikan menurut Undang-Undang 1945}

Undang - Undang Dasar 1945 adalah merupakan hukum tertinggi di Indonesia. Pasal-pasal yang berkaitan dengan pendidikan Bab XIII yaitu pasal 31 dan pasal 32. Pasal 31 ayat 1 berisi tentang hak setiap warga negara untuk mendapatkan pendidikan, sedangkan pasal 31 ayat 2-5 berisi tentang kewajiban negara dalam pendidikan. Pasal 32 berisi tendang kebudayaan. Kebudayaan dan pendidikan adalah dua unsur yang saling mendukung satu sama lain.

\section{- Undang-Undang RI Nomor 2 Tahun 1989 tentang Pendidikan Nasional}

Undang-undang ini memuat 59 Pasal yang mengatur tentang ketentuan umum (istilah-istilah dalam undang-undang ini), kedudukan fungsi dan tujuan, hak-hak warga negara untuk memperoleh pendidikan, satuan jalur dan jenis pendidikan, jenjang pendidikan, peserta didik, tenaga kependidikan, 
sumber daya pendidikan, kurikulum, hari belajar dan libur sekolah, bahasa pengantar, penilaian, peran serta masyarakat, badan pertimbangan pendidikan nasional, pengelolaan, pengawasan, ketentuan lain-lain, ketentuan pidana, ketentuan peralihan dan ketentuan penutup.

- Undang-Undang No. 20 Tahun 2003 tentang Sistem Pendidikan Nasional

Undang-undang ini selain memuat pembaharuan visi dan misi pendidikan nasional, juga terdiri dari 77 Pasal yang mengatur tentang ketentuan umum (istilah-istilah terkait dalam dunia pendidikan), dasar, fungsi dan tujuan pendidikan nasional, prinsip penyelenggaraan pendidikan, hak dan kewajiban warga negara, orang tua dan masyarakat, peserta didik, jalur jenjang dan jenis pendidikan, bahasa pengantar, stándar nasional pendidikan, kurikulum, pendidik dan tenaga kependidikan, sarana dan prasarana pendidikan, pendanaan pendidikan, pengelolaan pendidikan, peran serta masyarakat dalam pendidikan, evaluasi akreditasi dan sertifikasi, pendirian satuan pendidikan, penyelenggaraan pendidikan oleh lembaga negara lain, pengawasan, ketentuan pidana, ketentuan peralihan dan ketentuan penutup.

- Undang-Undang No. 14 Tahun 2005 Tentang Guru dan Dosen

Undang undang ini memuat 84 Pasal yang mengatur tentang ketentuan umum (istilah-istilah dalam undang-undang ini), kedudukan fungsi dan tujuan, prinsip profesionalitas, seluruh peraturan tentang guru dan dosen dari kualifikasi akademik, hak dan kewajiban sampai organisasi profesi dan kode etik, sanksi bagi guru dan dosen yang tidak menjalankan kewajiban sebagaimana mestinya, ketentuan peralihan dan ketentuan penutup.

- Undang-Undang No. 19 Tahun 2005 Tentang Standar Nasional Pendidikan

Undang-undang ini memuat 97 Pasal yang mengatur tentang Ketentuan Umum, Lingkup, Fungsi dan Tujuan, Standar Isi, Standar Proses, Standar Kompetensi Lulusan, Standar Pendidikan dan Tenaga Pendidikan, Standar Sarana dan Prasarana, Standar Pengelolaan, Standar Pembiayaan, Standar Penilaian Pendidikan, Badan Standar Nasional Pendidikan, Evaluasi, Akreditasi, Sertifikasi, Penjamin Mutu, Ketentuan Peralihan, Ketentuan 
Penutup.

Menurut Peraturan Pemerintah ini yang dimaksud dengan: "Standar nasional pendidikan adalah kriteria minimal tentang sistem pendidikan di seluruh wilayah hukum Negara Kesatuan Republik Indonesia”.

\section{Peraturan Pendidikan}

- Peraturan Pemerintah No. 19 Tahun 2005 Tentang Standar Nasional Pendidikan

- Peraturan Pemerintah No. 30 Tahun 1990 Tentang Status Pendidikan Pancasila dalam Kurikulum Pendidikan Tinggi sebagai mata kuliah wajib untuk setiap program studi dan bersifat nasional

- Peraturan Menteri No. 22 Tahun 2006 Tentang Standar Isi Untuk Satuan Pendidikan Dasar dan Menengah.

- Peraturan Menteri No. 23 Tahun 2006 Tentang Standar Kompetensi Lulusan

- Peraturan Menteri No. 24 Tahun 2006 Tentang Pelaksana Peraturan Menteri No. 22 dan No. 23

- Peraturan Menteri Nomor 13 Tahun 2007 Tentang Kepala Sekolah

- Peraturan Menteri Nomor 16 Tahun 2007 dan Nomor 32 Tahun 2008 Tentang Guru

- Peraturan Menteri Nomor 19 Tahun 2007 Tentang Standar Pengelolaan

- Peraturan Menteri Nomor 20 Tahun 2007 Tentang Standar Penilaian

- Peraturan Menteri Nomor 24 Tahun 2007 dan Permen Nomor 33 Tahun 2008 tentang Standar Sarana Prasarana.

- Peraturan Menteri Nomor 41 Tahun 2007 Tentang Standar Proses

- Peraturan Menteri Nomor 47 Tahun 2008 Tentang Standar Isi

- Peraturan Menteri Nomor 24 Tahun 2008 Tentang TU

- Peraturan Menteri Nomor 25 Tahun 2008 Tentang Perpustakaan

- Peraturan Menteri Nomor 26 Tahun 2008 Tentang Laboratorium

- Peraturan Menteri Nomor 39 Tahun 2008 Tentang Kesiswaan

- Keputusan Menteri No. 3 Tahun 2003 Tentang Tunjangan Tenaga Kependidikan

○ Keputusan Menteri No. 34/ U/03 Tentang Pengangkatan Guru Bantu 


\section{d. Implikasi Landasan Hukum Pendidikan di Indonesia}

Sebagai implikasi dari landasan hukum pendidikan, maka pengembangan konsep pendidikan di Indonesia adalah sebagai berikut :

1. Ada perbedaan yang jelas antara pendidikan akademik dan pendidikan profesional.

2. Pendidikan profesional tidak cukup hanya menyiapkan ahli dalam menerapkan satu teori, tetapi juga mempelajari cara membina tenaga pembantu dan mengusahakan alat-alat bekerja

3. Sebagai konsekuensi dari beragamnya kemampuan dan minat siswa serta dibutuhkannya tenaga kerja menengah yang banyak, maka perlu diciptakan berbagai ragam sekolah kejuruan.

4. Untuk merealisasikan terwujudnya manusia Indonesia seutuhnya maka perlu perhatian yang sama terhadap pengembangan afektif, kognitif dan psikomotor pada semua tingkat pendidikan.

5. Pendidikan humaniora perlu lebih menekankan pada pelaksanaan dalam kehidupan seharí-hari agar pembudayaan nilai-nilai Pancasila akan lebih mudah dicapai.

6. Isi kurikulum mulok agar disesuaikan dengan norma-norma, alat, contoh dan keterampilan yang dibutuhkan di daerah setempat.

7. Perlu diselenggarakan suatu kegiatan badan kerjasama antara sekolah masyarakat dan orang tua untuk menampung aspirasi, mengawasi pelaksanaan pendidikan, untuk kemajuan di bidang pendidikan.

Landasan hukum pendidikan merupakan seperangkat peraturan dan perundang-undangan yang menjadi panduan pokok dalam pelaksanaan sistem pendidikan di Indonesia. Peraturan yang satu dan yang lain seharusnya saling melengkapi. Permasalahan yang saat ini terjadi adalah perundangan dan peraturan yang ada belum sepenuhnya terlaksana dengan baik.

Pada batang tubuh UUD 1945 Pasal 31 Ayat 1 berbunyi : "Tiap - tiap warga negara berhak mendapatkan pengajaran". Pada kenyataannya masih banyak warga negara baik dari kelompok masyarakat miskin, daerah tertinggal dan sebagainya yang belum mendapatkan pengajaran seperti yang dimaksud dalam Undang-Undang tersebut. 
Pada UU No. 20 Tahun 2003 Tentang Sisdiknas Pasal 4 ayat 2 berbunyi : "Pendidikan diselenggarakan secara demokratis dan berkeadilan serta tidak diskriminatif dengan menjunjung tinggi hak asasi manusia, nilai keagamaan, nilai kultural, dan kemajemukan bangsa". Namun dalam kenyataanya sebagian penyelenggaraan pendidikan belum sesuai dengan peraturan tersebut. Penyelenggaraan pendidikan masih saja bersifat diskriminatif dan tidak menjunjung hak asasi manusia. Misalnya dalam penyelenggaraan pendidikan di RSBI dengan pelajarannya yang begitu padat siswa kehilangan hak-haknya untuk bermain, serta diskriminatif karena hanya siswa yang pandai dan mampu saja yang bisa menempuh pendidikan disana.

Kita akan masih banyak menemukan beberapa undang-undang yang belum mencapai tujuannya, karena bangsa Indonesia merupakan bangsa yang majemuk, tentu tidak mudah mencapai semua tujuan dengan singkat dan cepat. Tercapainya tujuan pendidikan membutuhkan dukungan positif dari pendukung segala aspek masyarakat, penyelenggara pendidikan dan pemerintah. Maka penyelenggaraan pendidikan yang baik adalah sesuai dengan landasan-landasan pendidikan. Pelaksanaan pendidikan yang berlandaskan hukum akan menjadikan penyelenggaraan pendidikan terarah, teratur dan sesuai dengan akar kebudayaan nasional.

\section{e. Masalah Hukum Pendidikan di Indonesia}

Para pendidik dan masyarakat umum perlu bersikap dan bertindak positif mensukseskan tujuan pendidikan tersebut, antara lain dengan cara :

1. Memberikan dorongan kepada peserta didik dan warga belajar untuk belajar terus

2. Mengurangi beban kerja anak-anak manakala mereka harus membantu meringankan beban ekonomi orang tuanya

3. Membantu menyiapkan lingkungan belajar dan alat-alat belajar di rumah untuk merangsang kemauan belajar anak-anak

4. Membantu biaya pendidikan

5. Mengijinkan anak pindah sekolah, bila ternyata sekolah semula sudah tidak dapat menampung

6. Bila diperlukan, membantu menyiapkan gedung untuk lokasi belajar 
7. Bersedia menjadi narasumber untuk keterampilan-keterampilan tertentu yang banyak dibutuhkan para pendidik dasar tingkat-tingkat akhir

8. Mengizinkan peserta didik dan warga belajar magang di perusahaanperusahaan dan perdagangan-perdagangan

9. Responsif terhadap kegiatan-kegiatan sekolah, terutama yang dilaksanakan di masyarakat

10. Bersedia menjadi orang tua angkat atau orang tua asuh bagi anak-anak yang sudah tidak memiliki orang tua, atau orang tuanya tidak mampu membiayai anak-anaknya.

\section{Informasi pendukung}

- Buku Kumpulan Peraturan Perundangan dalam Bidang Pendidikan

- Buku Pengantar Landasan Penyusunan Perundang-Undangan

\section{6.. Latihan-latihan}

1. Jelaskan dengan menggunakan bahasa sendiri apa yang dimaksud dengan landasan filosofis dalam penyusunan peraturan perundangan?

2. Jelaskan dan berikan contoh bahwa dalam penyusunan peraturan perundangan harus memperhatikan sisi sosiologis?

\section{Petunjuk kerja, dapat berupa Lembar Kerja (LK)}

-Kerjakan soal setelah Anda merasa sudah paham betul dengan bacaan diatas.

\section{Pengerjaan}

-Lengkapi dan berikan penjelasan dengan jelas setiap jawaban yang dikemukakan.

\section{Evaluasi}

Pilihlah jawaban yang benar untuk setiap pertanyaan di bawah ini dengan membubuhkan tanada silang (x) pada alternatif-alternatif jawaban yang ada.

1) Proteksi atas dampak yang muncul karena budaya, sosial, politis, dan lain-lain, disebut.....
a. .Kekuasaan
d. Aturan Lisan
b. Kekuatan
e. Undang-Undang

c.Peraturan

2) Peraturan muncul sebagai hasil dari kesepakatan diantara beberapa orang/masyarakat/komunitas yang berinteraksi untuk mengatur
a. Sistem Interaksi
b. Pola Interaksi 
c. Struktur Interaksi e.Kolaborasi

d.Gejala Interaksi

3) Penomena/gejala kemasyarakatan/penomena sosial, dimana masyarakat ada adalah.....
a.Peraturan
c. Solusi
b. Aturan
e.Hukum

d. Sistem Hidup

4) Mengarah kepada ketertiban dan keharmonisan dalam hidup dan kehidupan bermasyarakat adalah.....
a.Tujuan Hukum
d.Pola Hukum
b.Hakekat Hukum
e.Produk Hukum

c.Skema Hukum

5) Memberi kewenangan bagi instansi tertentu untuk membuat peraturan tertentu atau dasar hukum kewenangan, adalah fungsi:
a.Yuridis
b.Sosiologis
c.Praktis
d.Yuridis Formil
e.Yuridis Materi 
6) Respon atau balikan terhadap hasil evaluasi Setiap item jawaban yang benar diberkan nilai 20, bila Anda belum mencapai $80 \%$ untuk nilai yang diperoleh silahkan baca ulang dengan teliti dan baik, kemudian kerjakan kembali soal diatas.

\section{Keterangan}

$\frac{\text { Tingkat penguasaan }=\text { x } 100 \%}{100}$

Arti tinggkat penguasaan Anda:

$90 \%-100 \%$ = baik sekali

$80 \%-89 \%=$ baik

$70 \%-79 \%=$ cukup

$<70 \%=$ kurang 


\section{BAB III \\ PERKEMBANGAN PENDIDIKAN DI INDONESIA}

\section{Pokok Bahasan;}

\section{Perkembangan Pendidikan Di Indonesia}

\section{Kompetensi yang akan dicapai}

mahasisiwa memahami perkembangan pendidikan di indonesia

\section{Petunjuk belajar}

- Baca basmallah untuk memulainya.

- Baca dengan seksama setiap penjelasan yang ada dalam bagian materi.

- Perhatikan penjelasan dosen pada saat dosen sedangmenerangkan/menjelaskan.

- Buat rangkuman

- Kerjakan dengan baik soal-soal latihan yang ada.

\section{Konten atau isi materi pembelajaran}

\section{a. Sejarah pendidikan di Indonesia}

Pendidikan di Indonesia dipengaruhi dan mempengaruhi perkembanganzaman dimana pendidikan itu berlangsung. Kondisi ini terlihat dari perubahantujuanpendidikan yang terjadi dari waktu ke waktu. Dalam artikel ini akandibahas mengenaipengaruhpengaruh zaman terhadap pendidikan. Pengaruhzaman dibedakan kepada 1500 sebelum masehi, Zaman Hindu-Budha, Permulaanagama Islam, zaman Portugis dan Spanyol,zaman Belanda, masa awalkemerdekaan, dan masa mengisi kemerdekaan sampai saat ini.

Pada +1500 tahun sebelum masehi, dimana budaya yang berkembangmemiliki ciri :

A. Kebudayaan maritime

B. Kepercayaan animisme dan dinamisme, dan

C. Masyarakatnya merupakan masyarakat gotong royong.

Pendidikan saat itu berlangsung dalam lingkungan keluarga dimana seorang ayahmenjadipendidik bagi puteranya dan ibu menjadi pendidik bagi puterinya. Namunyang menarik, dalammasyarakat ada dua golongan yang yang mempunyaikecakapan istimewa yaitu pandai besidan dukun yang keduanya bergelar Empu.Empu merupakan anggota masyarakat biasa, tidakmerupakan kaum elit dalammasyarakat. Kepada empu-lah, pada saat itu orang-orang berguru.Adapun yangmenjadi tujuan pendidikannya adalah :

1. Manusia yang mempunyai semangat gotong royong, 
2. Manusia yang menghormati para empu,

3. Manusia yang taat akan adat.

Apabila dilihat dari budaya yang dimiliki dengan pendidikan yang berlangsung,maka terjadi interaksi antara keduanya.

\section{a) Masa Pengaruh Hindu dan Budha}

Pada masa pengaruh Hindu dan Budha, telah dikenal dengan pengkastaanmasyarakat.Pada saat itu dikenal kaum raja dan pegawai-pegawainya (yangdijamin) dan rakyat (yangmenjamin). Sebagai pengaruh Hindu dan Budha, gurudiambil dari kaum Brahmana yangmenggantikan para Empu. Namun setelahEmpu belajar kepada guru tersebut, maka empuempu tersebut menggantikankembali kedudukan Brahmana. Kondisi yang terjadi, empu initerbagi menjadi 2,yaitu : (1) Guru Keraton (Golongan yang dijamin) dan (2) Guru pertapa(menginsyafi tugasnya).

Ada perbedaan mendasar antara empu dengan guru, dimana empumerupakan anggota masyarakat, bukan orang atasa, sedangkan guru mengabdipada raja dan termasuk orang yangdijamin oleh rakyat. Sistem pendidikan yangdikembangkan adalah sistem "guru-kula" atau pendidikan asrama; murid tinggalbersama guru dan murid harus melayani guru.

\section{b) Masa Pengaruh Islam}

Islam masuk ke Indonesia melalui para perdagangan (para saudagar).Pengaruh agamaIslam berkembang melalui guru-guru pertapa, yang telahdiislamkan oleh para wali.

Dengan tujuan untuk memberikan pengetahuan tentang agama, ada dualembaga penting dalampenyebaran agama islam di Indonesia, yaitu langgar danpesantren. Langgar merupakanpengajaran agama permulaan dan pesantrenmerupakan pengajaran lebih lanjut dan lebihmendalam. Di Sumatera Barat,sekolah-sekolah Islam dinamakan "Surau." Sedangkan di Aceh disebut sebagai“Rangkang." System pendidikan diselenggarakan hampir mirip dengan systemguru kula atau asrama. Namun demikian ada perbedaan yang mendasar antara pendidikan dimasa pengaruh Hindu Budha dengan dimasa pengaruh Islam, yaitu pengajaran pada jaman Hindu-Budha diperuntukan hanya untuk kaum bangsawan saja, sedangkan pengajaran Islam diikuti oleh setiap orang yang menghendakinya.

\section{c) Zaman Portugis dan Spanyol}

Pada masa penjajahan Portugis dan Spanyol yang memiliki dua tujuan,yaitu perdagangan dan pengembangan Agama Nasrani, kedatangan mereka ketanah 
Indonesiadibarengi oleh Missionaris, yang secara khusus diberi tugas untukmengembangkan AgamaNasrani di Indonesia.

Pada tahun 1536, di Ternate didirikan sekolah agama, menulis, membacadan menghitung bagi anak-anak orang terkemuka yang disebut "Seminarie".Sedangkan untukpendidikan yang lebih tinggi diberikan di Goa; Pusat kekuasaanPortugis di Asia.

Seiring dengan hilangnya kekuasaan Portugis di Indonesia pada abad 16-an, maka hilangpulalah Misi pengembangan agama Kristiani. Karena misitersebut merupakan misi yangdidanai oleh negara.

\section{d) Zaman Pengaruh Belanda}

Berdasarkan pada anggapan orang-orang Belanda mengenai penyebaranKatholik olehPortugis di Indonesia, maka mereka mempunyai pemikiran untuk mendirikan sekolah-sekolahprotestan, terutama pada daerah-daerah dimanaportugis dahulu menjajah. Pada tahun 1607,VOC pertama kalinya mendirikansekolah di Ambon, dengan pelajaranpelajaran : membaca, menulis, dan sembah yang. Untuk gurunya, maka VOC mendatangkan dari Belanda, Bahasapengantar yang dipakai adalah Belanda, namun dalam perjalanannya terjadibanyak hambatan sehingga bahasa pengantar diganti menjadi bahasa melayu. 20tahun setelah itu (yaitu th.1627)di Ambon sudah ada 16 sekolahdan 18 sekolah dipulau sekitarnya.

Pendirian sekolah di pulau jawa tidak serapat di Maluku, karena rakyat diPulau Jawa sedikit sekali menghasilkan rempah-rempah untuk keperluan pasardunia dan rakyat di Pulau Jawa tidak terkena pengaruh Portugis. Tujuan pendidikan VOC adalah mengisi kekurangan tenaga-tenagapekerja, supaya dapat lebih memperkuat keuangan VOC. Berdasarkan haltersebut, maka rakyat tidak diberikan kesempatan untuk mendapatkan pendidikan.Baru setelah terjadi pengaruh "Aufklarung" :pencerahan, pendidikan yang nmembebaskan manusia, dan pencerahan (penerangan) bagirakyat umum,mulailah terjadi perubahan pada penyebaran dan isi pelajaran tersebut.

Pengaruh ini baru terwujud di masa VOC pada tahun 1808, pada saat ituPemerintahanDaendels memberikan perintah kepada para bupati di Pulau Jawaagar pengajaran disebarkan untuk semua rakyat di setiap distrik. Bahkan tahun1809,untuk pertama kalinya diselenggarakan pendidikan bidan. Namun adakehawatiran bagi Belanda, dengan pendidikan ini akan timbulnya kepahlawananpada rakyat Indonesia, sehingga pada tahun 1809 Belanda mendirikan sekolahRonggeng di Cirebon, dengan tujuan menjauhkan rakyat dari kepahlawanan.

Pada tahun 1818, Belanda mengeluarkan peraturan pemerintah yangmemuat peraturan umum mengenai persekolahan dan sekolah rendah. Isinyatidak lain berupa ketentuan-ketentuan mengenai pengawasan danpenyelenggaraan pendidikan. Namun 
pada tahun 1826 kegiatan pendidikanterganggu oleh usaha-usaha penghematan, sehingga urusan-urusan pengajaran disederhanakan. Sampai pada masa itu sekolah-sekolah yang ada tetap hanya diperbolehkan untu anak-anak Belanda dan anak-anak Indonesia yang memelukNasrani.Perkembangan baru muncul sekitar tahun 1849 - 1852, dimana Belandapada saat itumenerapkan Culturstelsel (tanam paksa). Belanda akhirnyamenyadari tentang kebutuhantenaga-tenaga "ahli" yang banyak. Sehingga dalamrentangan tahun tersebut didirikan 20 sekolah untuk anak-anak Indonesia di tiaptiapIbukota keresidenan. Ketika itu sudah ada 30sekolah untuk anak-anakBelanda.

Dalam perjalanannya, pendidikan ini mengalami 2 kendala, yaknimengenai bahasa pengantar di sekolah-sekolah Bumiputera dan kekurangan guru.Akhirnya diputuskan untuk bahasa pengantar pendidikan di daerah adalah Bahasa daerah, sedangkan bahasa melayu dijadikan salah satu mata pelajaran. Untukmengatasi kekurangan guru, untuk pertama kalinyadidirikan sekolah guru(kweekschool) pada th. 1852 di Surakarta.

Sekolah-sekolah yang berada di Pulau Jawa memiliki dukungan daribupatinya, berbeda dengan sekolah-sekolah yang berada di luar Pulau Jawa.Sekolah biasanya terletak di halaman kabupaten. Semua murid disatukandalamsatu kelas dan pada awalnya, murid-murid duduk di tanah. Isi mata pelajarandisesuaikan dengan keharusan sekolah untuk mendidik calon-calon pegawaiseperti : pelajaran mengukur tanah, berhitung, menggambar, dan ilmu pertanian.Murid-muridnya diambil dari golongan priyayi (anak-anak pegawai). Sedangkanuntuk rakyat masih belum diperkenankan. Namun hal ini berbeda kondisinyadengan sekolah-sekolah di luar pulau Jawa, dimana murid-muridnya terdiri darianak-anak pedagang dan petani. Akihir 1887 sekolah bumiputera di Pulau Jawamemiliki siswa 12.298. muri perempuan hanya berjumlah 25 murid. Berbeda darikondisi di luar Pulau Jawa, seperti di Ambon, dari jumlah total murid $5.546,2.384$ adalah perempuan.

Pada saat itu lama lama belajar sekolah tidak tentu, bisa 2 tahun bahkan 6tahun. Baru pada tahun 1893 lama belajar ditetapkan. Sekolah dibagi menjadi 2kelas, yaitu kelas I dan kelas II. Kelas I selama 3 tahun dan kelas II 5 tahun.Diawal pendirian kweekschool, guru-gurusekolah diambil dari sembarang posisi,seperti juru tulis, mantri gudang, dengan syarat bisa membaca, menulis danberhitung.

Pengaruh besar untuk mendirikan sekolah-sekolah juga ditimbukan olehmunculnya Undang-undang Agraris pada tahun 1870. akibat pengaruh ini makasekolah-sekolah Belanda menerima anak-anak Indonesia dan Cina asal memenuhisyarat-syarat. Sekolahpun mengalami perluasan dan penambahan jenisjenissekolah yang dibutuhkan sesuai dengan kebutuhan masyarakat. Usaha-usaha baruuntuk mendirikan sekolah terjadi pada tahun 1879 dengan didirikannya 
sekolahsekolahbumiputera di keresidenan Jogyakarta dan Surakarta. Kemudianmuculjuga sekolah yang lebih mendalami Bahasa Belanda, "Speciale School (sekolahistimewa) dan Hoofdenschool (Sekolah menak).

Tahun 1893 pemerintah Belanda menilai sekolah-sekolah Bumiputerakurang meuaskan, dikarenakan terlalu padatnya mata pelajaran yang diberikan.Disamping itu Belanda mulai menyadari akan pentingnya pendidikan bagi rakyatjelata. Melihat pada 2 analisa tersebut pad akhirnya Belanda mengadakandiferensiasi pendidikan, yaitu :

a. Lapisan atas membutuhkan pengajaran yang dapat membawanya ke arahkemajuan.

b. Lapisan rendah cukup dengan sekolah rendah yang sangat sederhanadengan materipokok : membaca, menulis dan berhitung.

Diferensiasi pendidikan ini berpengaruh pada reorganisasi Hoofdenschool dandibatasinya anak-anak Indonesia ke sekolah-sekolah Belanda.

\section{e) Awal Abad 20}

Kondisi rakyat Indonesia semakin miskin sedangkan jumlah semakinpenduduknya banyak, berbeda dengan Belanda yang maju pesat dalamperindustriannya. Akibatnya daya beli rakyat Indonesia menurun yangmenimbulkan hilanganya import dari Belanda. Menghadapi hal ini, Belanda padaakhirnya memberlakukan "politik Etika" yang secara resmi diberlakukanpadatahun 1901. politik ini bertujuan untuk memberikan kebahagiaan dankemakmuran kepada bangsa lain dengan menyelenggarakan pendidikan,pengairan dan perpindahan penduduk (emigrasi).

Implikasi "Politik Etika" dalam pendidikan pada saat itu adalah 2 tindakanpenting yang dilakukan oleh Belanda, yaitu

1. Memberi corak dan sifat ke-Belanda-belandaan pada sekolah-sekolah kelas I

2. Mendirikan sekolah-sekolah desa. (1907)

Kemudian didirkan sekolah Vervolg (1915), yaitu sekolah lanjutan darisekolah desa selama 2 tahun. Akibat krisis pada tahu 1929, sekolah-sekolah kelasII diubah menjadi sekolah-sekolah desa. Sehingga ada 3 pengajaran rendah diIndonesia pada saat itu, yaitu:

1. Sekolah desa, bagi anak-anak rakyat jelata

2. Sekolah kelas II, yang kemudia diubah menjadi sekolah vervolg

3. sekolah kelas I (6 tahun), yang sejak tahun 1914 dijadikan HIS

(Hollands Inlandse School).

Akibat dari hal tersebut, terjadi perpecahan antara rakyat Indonesia sendiri, yaitumunculnya golongan yang merasa lebih tinggi dari golongan lainnya.

Untuk melanjutkan ke pendidikan selanjutnya, Belanda meresmikanMULO (meer uitgebreid lager onderweijs) pada tahun 1914. 2 tahun sebelumnyaMulo berupa 
kursus 2 tahun bagi yang telah menamatkan sekolah HIS. Setelahdiresmikan lama belajar berubah menjadi 3 tahun. Kemudian setelah berjalanbeberapa tahun Mulo, Pemerintah Belanda mendirikan AMS (AlgemenMiddelbare School) sebagai sekolah lanjutan setelah lulus dari Mulo. AMS secara resmi didirkan pada tahun 1919 di Yogya.

Sebagai akibat tuntutan peningkatan ekonomi, pada tahun 1909 pemerintahmembuka 3 sekolah pertukangan di Jakarta, Surabaya dan Semarang.Pengajaran pertukangan ini meliputi 2 macam: tukang-tukang biasa dantukang-tukang yang dpat mengisi jabatan rendah dan mempunyai tugasmengawasi. Untuk tukang-tukang biasa diambil dari lulusan sekolah kelas IIselama 2 tahun. Untuk tukang-tukang satunya pendidikan dilakukan selama 3tahun. Selain itu juga dibuka pengajaran teknik pada tahun 1906 di Jakartayang benama "Koningin Wilhelmina School" (KWS).

Pengajaran perniagaan terdiri dari 3 tingkatan yaitu :

1. Sekolah malam (1914) di Surabaya.

2. Sekolah dagang rendah selama 3 tahun. Muridnya adalah lulusan HIS (sekolah rendah Belanda).

3. Sekolah dagang Menengah (1935) 3 tahun. Muridnya adalah merekayang lulus Mulo.

\section{f) Zaman Pengaruh Jepang}

Landasan idiil pendidikan pendudukan Jepang dikenal dengan "Hakko IChiudisamarkan sebagai kerjasama Indonesia Jepang untuk mencapaikemakmuran bersama Asia- Timur Raya. Tujuannya adalah menyediakan tenagayangterampil dan prajurit yang siap untuk membantu peperangan bagikemiliteran, dan indoktrinasi ketat.

System persekolahan pada saat itu menggunakan system tiga jenjang,yaitu pendidikan dasar 6 tahun (sekolah rakyat=Kokumin Gakko), pendidikanmenengah 6 tahun (sekolah menengah pertama $=$ Shoto chu gakko dan Sekolahmenengah tinggi = Kotto chu Gakko) dan pendidikan tinggi. Pada saat itu pulaBahasa Indonesia menjadi bahasa pengantar nomor satu.

\section{g) Masa Perjuangan Kemerdekaan}

Pada masa ini banyak sekali jenjang dan jenis pendidikan dan pegajaran yang dikelola oleh para pejuang Indonesia, antara lain :

1. Majelis Luhur Taman Siswa 
Didirikan oleh Suwardi Suryaningrat atau Ki Hajar Dewantara pada 3 Juli1922di Yogyakarta. Tujuannya adalah membangun anak didik menjadi manusiayang merdeka lahir dan batin, luhur akal budinya, serta sehat jasmani untukmenjadi anggota masyarakat yang berguna bagi nusa dan bangsa.

Sumbangan besar Perguruan Taman Siswa (berubah pada 1930), yaitu prinsipprinsippendidikan yang dikembangakan di Perfuruan Taman Siswa : Hing ngarsasung tulada (didepan memberikan teladan), Hing madya mangun karsa (ditengahikut serta membetuk kehendak), tutwuri handayani (dibelakang tetapmempengaruhi dengan memberikan kesempatan pada anak-anak).

2. Pendidikan INS Kayu Tanam

Didirikan oleh Muhamad Syafei pada tahun 1926 di Sumatera Barat.Orientasi pendidikan adalah sekolah praktik dari dan untuk rakyat.

3. Muhamadiyyah

Muhamadiyyah didirikan oleh K.H Ahmad Dahlan pada tahun 18 November1912 di Yogakarta. Sedangkan sekolah Muhamadiyyah didirikan pada tahun 1911di Yogyakarta. Titik berat pendidikan adalah perjuangan Muhamadiyyah kepadapendidikan bagi masyarakat yang sangat terbelakang akibat politik pemerintahanHindia Belanda.

\section{Pendidikan Ma'arif}

Didirikan pada tahun 1916 yang semula berupa kursus perdebatan oleh K.H.Abdul Wahab Hasbullah dan K.H. Masmansur bernama Taswirul Afkar. Laludijadikan lembaga perundingan bernama Jam'iyah Nahdatul Wathonyangbetujuan memperluas dan meningkatkan mutu pendidikan madrasah.

\section{h) Masa Permulaan Kemerdekaan (1945 - 1950)}

Sejak proklamasi kemerdekaan, Pancasila tetap merupakan landasan idiilpendidikan nasional bangsa Indonesia. Tujuan pendidikan saat itu lebihmenitikberatkan pada penanaman semangat dan jiwa kepahlawanan. Dalamrentang waktu 1945-1950, sistem persekolahan yang dikembangkan di Indonesiameliputi pendidikan rendah, pendidikan guru, pendidikan umum, pendidikankejuruan, dan pendidikan tinggi.

Pada masa ini, pendidikan menjadi hak yang sama untuk setiap warganegara yang telah memenuhi syarat-syarat yang ditentukan. Kurikulum yangsemula diorientasikan pada kepentingan kolonial, setelah merdeka diselaraskandengan kebutuhan bangsa yang merdeka. 


\section{i) Masa Permulaan Kemerdekaan (1951 - 1969)}

Pada masa ini, Pancasila masih menjadi landasan idiil pendidikan,walaupun terjadi pertikaian antara republik dengan golongan PKI, yang berakhirpada 30 September 1965. semua itu berdampak pada perkembangan pendidikan.pertikaian ini mengarah pada ideology bangsa.

Sejak tahun 1950, berlaku system persekolahan lima tingkat, yaitu :

prasekolah, pendidikan dasar, SLTP, SLTA, dan perguruan tinggi.Karenaberkembanganya pendidikan sebagai realisasi pemenuhan hak setiap warganegara, maka pada tahun 1950-an didirikan berbagai sekoah guru seperti SGB,PGSLB, dan lain sebagainya.

\section{j) Masa Pembangunan Jangka Panjang I (PJP I) (1969-1994)}

Pada masa ini, junlah lulusan semakin besar yang mendorong pertumbuhan SLTP dan SLTA. Dari masa ke masa inilah terjadi penyempurnaantujuan pendidikan nasional. Undang-undang pendidikan yang berlaku adalah UUno.4/1950 jo UU No. 12/1954 dan UU No.22/1961. Pada masa ini, pendidikandikaitkan dengan upaya pemberantasan buta aksara, latin dang angka, buta BahasaIndonesia, dan buta pendidikan dasar.

Pada tahun 1989 dilahirkan UUSPN No. 2/1989 yang merupakanperwujudan dari system pendidikan nasional seperti yang diamanatkan oleh UUD1945, pasal31 pendidikan adalah tanggung jawab keluarga, masayarakat danpemerintah.

\section{k) Masa 1994 - sampai sekarang}

Tahun 1997 sebagai titik awal bergulirnya Reformasi di semua bidang yang titik kulminasinya adalah pergantian presdiden Republik Indonesia dariSoeharto kepada Habibi membawa pengaruh terhadap dunia pendidikan.Munculan gagasan untuk penyempurnaan UUSPN No.2 tahun 1989 menjadiUUSPN No. 20 tahun 2003, yang lebih menitikberatkan pada demokratisasipendidikan.

\section{Evaluasi I}

1. Diambil dari manakah guru ketika pengaruh Hindu-Buddha berlangsung ?
a. Brahmana
b. Ksatria
c. Waisya
d. Sudra

2. Yang memberikan pengaruh pertama pada pendidikan di Indonesia adalah....
a. Pengaruh
b. Pengaruh
c. Pengaruh
d. Pengaruh
Hindu-
Islam
Nasrani
Kristen

Buddha 
3. Tujuan Pendidikan adalah....
a. Mencerdaskan Kehidupan Bangsa
b. Mencari Uang
c. Mencari jodoh
d. Mendapatkan ridho Allah

4. Pada tahun berapakah didirikannya sekolah di Ternate ?
a. 1520
b. 1535
c. 1563
d. 1536

5. Apa sebutan sekolah yang didirikan di Ternate?
a. Missionaris
b. Seminarie
c. Surau
d. Rangkan

6. Apa tujuan didirikannya pendidikan VOC pada zaman pengaruh Belanda ?
a. Mengisi kekurangan tenaga-tenaga pekerja supaya dapat lebih memperkuat keuangan VOC
b. Pengembangan agama
c. Memberi corak ke balanda-belandaan
d. Kerja paksa

7. Dimana VOC mendirikan sekolah yang pertama kali, dan tahun berapa ?
a. Ambon, 1607
b. Aceh,
c. Cirebon,
d. Maluku, 1607 1670 1607

8. Tiga system persekolahan di Indonesia pada zaman pengaruh jepang, kecuali...
a. Sekolah Rakyat (Kokumin Gakko)
b. Shoto Chu Gakko ( SMP)
c. Kotto Chu Gakko (SMA)
d. Shoto Kokumin Gakko

9. Ada berapa pengajaran rendah di Indonesia pada saat pengaruh belanda?....
a. 3
b. 4
c. 5
d. 6

10. Apa tujuan Portugis dan Spanyol datang ke Indonesia?...
a. Perdagangan dan pengembangan agama Nasrani mengajar
c. Untuk
b. Menguasai Indonesia jalan
d. Untuk jalan-

\section{Evaluasi II}

1. Apa nama sekolah yang ada di Sumatra Barat dan di Aceh?

2. Kendala apa saja yang dialami Indonesia pada saat pengaruh Belanda?

3. Tujuan didirikannya pendidikan VOC? 
4. Dimanakah pertama kalinya VOC mendirikan sekolah, dan pelajaran apa yang diajarkannya?

5. Apa yang menyebabkan pemerintah Belanda menilai sekolah Bumi Putera kurang memuaskan?

\section{Kunci jawaban}

Evaluasi I

1. A

2. A

3. A

4. D

5. B

6. A

7. A

8. D

9. A

10. A

Evaluasi II

1. Surau dan Rangkang

2. Bahasa pengantar di sekolah-sekolah Bumi Putera dan kekurangan Guru

3. Mengisi kekurangan tenaga-tenaga kerja untuk menguatkan keuangan VOC

4. Di Ambon, membaca, menulis, dan sembahyang

5. Karena terlalu padatnya mata pelajaran yang diberikan

\section{Daftar Pustaka}

https://www.google.co.id/search?client=ms-androidxiaomi\&q=bahan+ajar+perundang+undangan+pendisikan\&oq=bahan+ajar+perundang+ undangan + pendisikan\&aqs=mobile-gws-lite. . 


\section{BAB IV \\ PERKEMBANGAN HISTORIS PERUNDANG-UNDANGAN PENDIDIKAN (PUUP)}

\section{Pokok Bahasan}

Perkembangan Historis Perundang-undangan Pendidikan (PUUP)

\section{Kompetensi yang akan dicapai}

- Pengetahuan tentang perkembangan peraturan perundangan dalam bidang pendidikan

- Pemahaman tentang perubahan setiap tahapan dalam perubahan perturan perundangan pendidikan

\section{Petunjuk belajar}

- Baca basmallah untuk memulainya

- Baca dengan seksama setiap penjelasan yang ada dalam bagian materi

- Perhatikan penjelasan dosen pada saat dosen sedang

- Bertanya jika ada pembahasan yang kurang jelas/dimengerti

- Menerangkan/menjelaskan

- Buat rangkuman

- Kerjakan dengan baik soal-soal latihan yang ada

\section{Materi Pembahasan}

Undang-undang dan peraturan pemerintah sangat berperan demi terwujudnya sebuah tata kelola suatu negara. Di Indonesia banyak sekali UU dan PP yang telah disepakati bersama oleh pemerintah sesuai dengan bidangnya masing-masing. Misalnya bidang Pendidikan, mulai dari UU tentang Sistem Pendidikan Nasional, tentang guru, tentang pengelolaan dan penyelenggaraan pendidikan, serta pernak-pernik peraturan tentang pendidikan lainnya. ${ }^{(1)}$

Dalam sejarah perkembangan pendidikan di Indonesia, kita telah memiliki tiga undang-undang yang mengatur tentang sistem pendidikan nasional.

\section{a. Sistem Pendidikan menurut UU Nomor 4 Tahun 1950}

Undang-Undang Nomor 4 Tahun 1950, jo UU Nomor 12 Tahun 1954 merupakan Undang-Undang tentang Sistem Pendidikan Nasional yang pertama di Indonesia. Tentu saja, penyelenggaraan pendidikan tidak lahir begitu saja tanpa melalui proses perjalanan panjang proses pendidikan itu sendiri. Pendidikan 
adalah bukan persiapan hidup, tetapi pendidikan adalah kehidupan itu sendiri. Education is not a preparation of life, but it's life itself, demikianlah pendapat John Dewey, seorang tokoh pendidikan yang terkenal. Oleh karena itu, meski Undang-Undangnya telah terbentuk pada tahun 1950, tetapi proses pendidikan masih berlangsung dengan sistem kolonial, dan baru mengalami perubahan setelah undang-undangnya mulai berlaku, dari UUD RIS menjadi UUD Negara Kesatuan.

Undang-undang ini secara revolusi dapat direvisi setelah nagara ini berjalan selama empat tahun, karena Undang-undang Sistem Pendidikan Nasional lahir dengan Undang-Undang tentang Pendidikan dan Pengajaran Nomor 12 Tahun 1954 dalam masa pergolakan untuk mengubah sistem pemerintahan dari negara serikat kembali menjadi negara kesatuan. Pada tanggal 29 Desember 1945 BP-KNIP (Badan Pekerja Komite Nasional Indonesia Pusat) telah mengusulkan kepada Kementerian Pendidikan, Pengajaran, dan Kebudayaan (PP dan K) satu rencana pokok pendidikan dan mengajaran baru yang akhirnya melahirkan UU Nomor 4 Tahun 1950 tentang Sistem Pendidikan Nasional. Pada tanggal 1 Maret 1946 Nomor 104/Bg. BP-KNIP (Badan Pekerja Komite Nasional Indonesia Pusat) mengeluarkan surat keputusan untuk membentuk Panitia Penyelidik Pengajaran RI di bawah pimpinan Ki Hajar Dewantara yang dibantu seorang penulis Soegarda Poerbakawatja yang menghasilkan "kurikulum" baru bagi sistem pendidikan yang masih berbau kolonialistik pada saat itu. Hasil karya Panitia Penyelidik Pengajaran inilah yang kemudian manjadi cikal bakal kurikulum pertama di Indonesia yang ketika itu istilah "kurikulum" belum diadopsi dalam Bahasa Indonesia. Itulah sebabnya kurikulum pertama terkenal dengan nama "Rencana Pelajaran 1947", yang kemudian menjadi cikal bakal tersusunnya Undang-Undang Nomor 4 Tahun 1950 yang sekaligus menjadi Undang-Undang Sistem Pendikan dan Pengajaran yang pertama di Indonesia pada tanggal 2 April 1950.

Ada dua bagian tujuan pendidikan nasional dalam undang-undang ini, yakni mencerdaskan kehidupan bangsa dan mengembangkan manusia Indonesia seutuhnya, yang dapat dimaknai sama dengan manusia cerdas secara komprehensif sebagaimana yang telah dirumuskan dalam Renstra Kementerian Pendidikan 2004 - 2009 sebagaimana yang telah dijelaskan, yakni memiliki enam tipe kecerdasan secara utuh. 


\section{b. Sistem Pendidikan menurut Undang-Undang Nomor 2 Tahun 1989}

Dalam Undang-Undang Sistem pendidikan nasional Nomor 2 tahun 1989 telah memberikan warna baru untuk lembaga pendidikan Islam karena dengan diberlakukannya UUSPN No 2 tahun 1989 madrasah-madrasah mendapat perlakuan yang sama dengan sekolah umum lainnya karena dalam UUSPN tersebut madrasah dianggap sebagai sekolah umum yang berciri khas Islam dan kurikulum madrasah sama persis dengan sekolah umum plus pelajaran agama Islam sebanyak tujuh mata pelajaran. Selain masalah diakunya atau disamakannya kedudukan pendidikan agama atau madrasah sebagaimana sekolah umum, ada beberapa hal yang berbeda dari ssitem sebelumnya di antaranya mengenai sistem pendidikan dan sistem persekolahan yang meliputi Sistem pendidikan jalur pendidikan sekolah dan sistem pendidikan luar sekolah.

Sedangkan sistem persekolahan meliputi tiga jenjang yaitu:

1. Pendidikan dasar,

2. Pendidikan Menengah,

3. Pendidikan tinggi. ${ }^{(2)}$

\section{c. Sistem Pendidikan menurut Undang-Undang No. 20 Tahun 2003}

Undang-Undang No. 20 Tahun 2003 tentang Sistem Pendidikan Nasional tetap mempertahankan dasar pendidikan nasional adalah Pancasila dan UndangUndang Dasar 1945. Hal tersebut termasuk dalam Bab II pasal 2 yang bunyi lengkapnya adalah "Pendidikan nasional berdasarkan Pancasila dan UndangUndang Dasar Negara Republik Indonesia Tahun 1945”. Sedangkan fungsi dan tujuan pendidikan nasional tercantum dalam Bab II pasal 3 yang berbunyi "Pendidikan nasional berfungsi mengembangkan kemampuan dan membentuk watak serta peradaban bangsa yang bermartabat dalam rangka mencerdaskan kehidupan bangsa, bertujuan untuk berkembangnya potensi peserta didik agar menjadi manusia yang beriman dan bertakwa kepada Tuhan Yang Maha Esa, berakhlak mulia, sehat, berilmu, cakap, kreatif, mandiri, dan menjadi warga negara yang demokratis serta bertanggung jawab”.

Undang-undang sisdiknas terbaru ini memberikan penekanan bahwa penyelenggaraan pendidikan harus dilaksanakan secara demokratis dan berkeadilan serta tidak diskriminatif dengan menjunjung tinggi hak asasi manusia, nilai keagamaan, nilai kultural, dan kemajemukan bangsa. Pendidikan diselenggarakan sebagai satu kesatuan yang sistemik dengan sistem terbuka dan 
multi makna. Selain itu, pendidikan diselenggarakan: sebagai suatu proses pembudayaan dan pemberdayaan peserta didik yang berlangsung sepanjang hayat dengan memberi keteladanan, membangun kemauan, dan mengembangkan kreativitas peserta didik dalam proses pembelajaran; dengan mengembangkan budaya membaca, menulis, dan berhitung bagi segenap warga masyarakat; dan dengan memberdayakan semua komponen masyarakat melalui peran serta dalam penyelenggaraan dan pengendalian mutu layanan pendidikan. Undang-Undang No.20/2003 Bab VI pasal 13 menetapkan bahwa pendidikan nasional dilaksanakan melalui jalur formal, non formal, dan informal yang penyelenggaraannya dapat saling melengkapi dan saling memperkaya. ${ }^{(3)}$

\section{KESIMPULAN}

Dari uraian di atas secara singkat dapat disimpulkan bahwa sistem pendidikan nasional yang diatur UU No. 4/1950 jo UU No. 12/1954 masih belum terintegratif dan utuh. Sistem pendidikan nasional yang terintegratif dan utuh mulai muncul pada UU NO. 2/1989, namun pada undang-undang ini hakikat pendidikan yang menghargai keragaman belum terakomodasi. Sistem pendidikan nasional menurut UU NO. 2/1989 masih bersifat sentralistik. Bangun sistem pendidikan nasional paling komprehensif dan desentralistik sudah terlihat pada UU No. 20/2003. Undang-undang ini sangat kuat, karena pada tahun yang sama UUD 1945 juga diamandemen dan hasilnya menempatkan pendidikan pada posisi sangat penting, alokasi anggaran pendidikan diamanatkan minimal $20 \%$ dari APBN. Namun demikian, pelaksanaannya sampai tahun kelima (2008) masih belum sempurna. Alokasi anggaran pendidikan masih kurang dari $20 \%$ dari APBN 


\section{PERTANYAAN}

\section{PILIHAN GANDA:}

1. ketentuan yang dibuat oleh pemerintah yang berfungsi untuk mengatur berjalannya suatu undang-undang ialah pengertian dari....?
a. Undang-undang Dasar (UUD)
b. Undang-Undang (UU)
c. Peraturan Pemerintah (PP)
d. Pendidikan Pengajaran, dan kebudayaan (PP dan K)

2. Dalam setiap sistem adanya tiga unsur penting yaitu,... kecuali?
a. Adanya komponen dari sistem tersebut
b. Adanya komponen yang tidak berkaitan
c. Adanya interrelasi dan interaksi yang saling berkaitan
d. Adanya tujuan yang hendak dicapai

3. Dalam sistem pendidikan nasional kita mengenal adanya komponen utama yaitu... kecuali?
a. Sarana dan prasarana pendidikan
b. Kurikulum
c. Peserta didik
d. Guru/pendidik

4. Undang-undang manakah yang pertama mengatur sistem pendidikan di Indonesia?
a. UU No 12 tahun 1954
b. UU No 12 tahun 1989
c. UU No 4 tahun 1945
d. UU No 4 tahun 1950

5. Pada tahun berapakah undang-undang no. 12 tentang persyaratan berlakunya undang-undang no.4 tahun 1950 ?
a. Tahun 1955
b. Tahun 1947
c. Tahun 1954
d. Tahun 1989

6. Pada tahun berapakah renstra departemen pendidikan nasional merumuskan tujuan pendidikan? 

a. $2001-2005$
b. $2005-2009$
c. $1999-2003$
d. $2006-2010$

7. Undang-undang No 20 tahun 2003 bab VI pasal 13 menetapkan bahwa pendidikan nasional dilaksanakan melalui jalur.... kecuali?
a. Nonformal
b. Formal
c. Informal
d. NMN

8. Undang-undang No 4 tahun 1950 menjadi sistem pendidikan dan pengajaran pada tanggal?
a. 2 Maret 1950
b. 2 April 1950
c. 2 Mei 1950
d. 2 Juni 1950

9. Siapakah tokoh-tokoh pendidikan nasional.. kecuali?
a. Kiai hasyim asy'ari
b. Dokter sutomo
c. Ki Hadjar dewantara
d. Rabbani

10. Siapakah tokoh pendidikan terkenal yang berpendapat mengenai Education is not a preparation of life, but it's life itself?
a. Howard Gardner
b. John Dewey
c. John Locke
d. Ki Hajar Dewantara

\section{ESSAY}

1. Sebutkan 3 undang-undang yang mengatur tentang sistem pendidikan?

2. Uraikan pengertian dari sistem pendidikan nasional ? 
3. Sebutkan isi pokok dari tujuan dari undang-undang No.2 tahun 1989 bab II pasal 4?

Uraikan fungsi pendidikan nasional yang tercantum dalam undang-undang No.20 tahun 2003 bab II pasal 3?

4. Dalam undang-undang No.4 tahun 1950 bab II pasal 3 disebutkan bahwa pendidikan nasional bertujuan?

5. Dalam undang-undang No.4 tahun 1950 bab II pasal 3 disebutkan bahwa pendidikan nasional bertujuan?

\section{KUNCI JAWABAN}

\section{PILIHAN GANDA:}

1. $\mathrm{C}:$ Peraturan Pemerintah (PP)

2. B : Adanya komponen yang tidak berkaitan

3. A : Sarana dan prasarana pendidikan

4. D : UU No 4 tahun 1950

5. C: Tahun 1954

6. B : 2005-2009

7. D : NMN

8. B : 2 April 1950

9. D : Rabbani

10. B : John Dewey

\section{ESSAY :}

1. - UU No.4 tahun 1950 jo.

- UU No.12 tahun 1954

- UU No.2 tahun 1989

- UU No.20 tahun 2003

2. Sistem pendidikan nasional adalah keseluruhan komponen pendidikan yang saling terkait secara terpadu untuk mencapai tujuan pendidikan nasional.

3. Mencerdaskan kehidupan bangsa dan mengembangkan manusia indonesia seutuhnya. 
4. Pendidikan nasional berfungsi mengembangkan kemampuan dan membentuk watak serta peradaban bangsa yang bermartabat dalam rangka mencerdaskan kehidupan bangsa.

5. Pendidika nasional bertujuan untuk membentuk manusia susila yang cakap dan warga negara yang demokrasi serta bertanggung jawab tentang kesejahteraan masyarakat dan tanah air. 


\section{BAB V}

\section{FUNGSI DAN HIERARKI PUUP}

\section{Pokok Bahasan;}

Fungsi dan Hierarki PUUP

\section{Capaian Kompetensi}

- Pemahaman tentang fungsi peraturan perundangan dalam bidang pendidikan.

- Pemahaman tentang peraturan perundangan pendidikan dalam struktur hierarki peraturan perundangan.

\section{Petunjuk belajar}

- Baca basmallah untuk memulainya.

- Baca dengan seksama setiap penjelasan yang ada dalam bagian materi.

- Perhatikan penjelasan dosen pada saat dosen sedang menerangkan/menjelaskan.

- Buat rangkuman.

- Kerjakan dengan baik soal-soal latihan yang ada.

\section{Konten atau isi materi pembelajaran}

\section{a. Pengertian Peraturan Perundangan}

Peraturan berasal dari kata aturan, yang berarti seperangkat ketetapan yang diperlukan agar ada efisiensi dalam usaha mengejar sebuah tujuan. Peraturan adalah penunjuk tentang tingkah laku yang harus dilakukan atau tidak boleh dilakukan. Perundang-undangan berasal dari kata undang-undang, yang berarti ketentuan peraturan yang disusun oleh pemerintah dan disahkan oleh DPR dan unsur-unsur terkait. Undang-undang dibuat dan disepakati, gunanya sama dengan peraturan yaitu untuk mengatur kehidupan kita semua.

Jadi, Peraturan Perundang-undangan adalah peraturan tertulis yang dibentuk oleh lembaga negara atau pejabat yang berwenang dan mempunyai kekuatan yang mengikat. Tujuan undang-undang dan peraturan negara adalah untuk mengatur dan menertibkan setiap kehidupan berbangsa dan bernegara. Dengan undang-undang atau peraturan, kehidupan berbangsa dan bernegara menjadi lebih tertib.

Peraturan perundang-undangan dan peraturan memiliki kekuatan mengikat atau undang-undang dan peraturan itu harus dilaksanakan. Seseorang 
yang melanggar peraturan dan undang-undang, akan dikenai sanksi atau hukuman. Hukuman itu dapat berupa denda atau pun kurungan penjara. Kita sebagai warga negara harus taat kepada peraturan yang sudah dibuat ataupun diberlakukan oleh negara. Jadi, undang-undang harus kita tegakan dan peraturan harus kita taati. ${ }^{5}$

\section{b. Fungsi PUUP}

Secara umum, peraturan perundang-undangan fungsinya adalah "mengatur" sesuatu substansi untuk memecahkan suatu masalah yang ada dalam masyarakat. Artinya, peraturan perundang-undangan adalah sebagai instrumen kebijakan (beleids instrument) apapun bentuknya, apakah bentuknya penetapan, pengesahan, pencabutan, maupun perubahan. Secara khusus fungsi peraturan perundang-undangan dirinci sebagai berikut:

- Fungsi UUD yang utama adalah membatasi dan membagi kewenangan para penyelenggara pemerintahan negara, sehingga dapat tercipta keterkendalian dan keseimbangan (checks and balances) diantara para penyelenggara pemerintahan negara sesuai dengan asas trias politica (distribution of powers) dan menciptakan penyelenggaraan pemerintahan yang baik dan bersih (clean governance/goverment). ${ }^{6}$

Berikut isi Undang-Undang 20/2003, pasal 4:

1. Pendidikan diselenggarakan secara demokratis dan berkeadilan serta tidak diskriminatif dengan menjunjung tinggi hak asasi manusia, nilai kegamaan, nilai kultural, dan kemajemukan bangsa.

2. Pendidikan diselenggarakan sebagai satu kesatuan yang sistemik dengan sistem terbuka dan multimakna.

3. Pendidikan diselenggarakan sebagai suatu proses pembudayaan dan pemberdayaan peserta didik yang berlangsung sepanjang hayat.

4. Pendidikan diselenggarakan dengan memberi keteladanan, membangun kemauan dan mengembangan kreativitas peserta didik dalam proses pembelajaran.

5. Pendidikan diselenggarakan dengan mengembangkan budaya membaca, menulis dan berhitung bagi segenap warga masyarakat.

\footnotetext{
${ }^{5} \mathrm{http}: / /$ sekilaspendidik.blogspot.co.id/2013/03/peraturan-perundang-undangan.html

${ }^{6}$ https://rudini76ban.wordpress.com/2009/03/21/fungsi-peraturan-perundang-undangan/
} 
6. Pendidikan diselenggarakan dengan memberdayakan semua komponen masyarakat melalui peran serta dalam penyelenggaraan dan pengendalian mutu layanan pendidikan. ${ }^{7}$

\section{c. Hierarki PUUP}

Hierarki maksudnya peraturan perundang-undangan yang lebih rendah tidak boleh bertentangan dengan peraturan perundang-undangan yang lebih tinggi.

Sebuah hierarki dapat menautkan entitas-entitas baik secara langsung maupun tidak langsung, dan baik secara vertikal maupun horizontal. Satusatunya tautan langsung pada sebuah hierarki, sejauh mereka hierarkis, adalah kepada yang berada di posisi superior maupun kepada yang berada di posisi subordinat secara langsung, meskipun sebuah sistem yang hierarkis secara lebih luas bisa mengadopsi bentuk hierarki alternatif. Tautan hierarkis tidak langsung bisa diperluas "secara vertikal" ke atas maupun ke bawah melalui beberapa tautan dalam arah yang sama, mengikuti sebuah jalur. Semua bagian dari hierarki yang tidak bertaut secara vertikal kepada yang lain dapat bertaut "secara horizontal" melalui sebuah jalur dengan menelusuri hierarki untuk menemukan superior bersama yang berhubungan langsung maupun tidak langsung, dan kemudian ke bawah lagi. Hal ini mirip dengan rekan kerja atau kolega, masing-masing memiliki kewajiban untuk bertanggungjawab pada atasan bersama, tetapi mereka sama-sama memiliki otoritas yang relatif sama.

Dalam kajian hukum, tata urutan peraturan perundang-undangan disusun berdasarkan pandangan bahwa sistem hukum merupakan sistem hierarki dengan kaidah berjenjang dimana norma hukum yang paling rendah harus berpegangan pada norma hukum yang lebih tinggi. Hal ini sesuai Teori Stufenbau (Stufen Theory) atau yang dipopulerkan oleh ahli ilmu hukum yang bernama Hans Kelsen yang menyatakan bahwa sistem hukum merupakan sistem anak tangga dengan kaidah berjenjang dimana norma hukum yang paling rendah harus berpegangan pada norma hukum yang lebih tinggi, dan kaidah hukum yang tertinggi (seperti konstitusi) harus berpegangan pada norma hukum yang paling mendasar (grundnorm). Menurut Kelsen norma hukum yang paling dasar

${ }^{7}$ http://imajinasichepyo.blogspot.co.id/2013/04/dasar-fungsi-dan-tujuan-pendidikan.html 
(grundnorm) bentuknya tidak kongkrit (abstrak) .Contoh norma hukum paling dasar abstrak adalah Pancasila. ${ }^{8}$

Tata urutan hierarki peraturan perundang - undangan di indonesia menurut Undang- Undang Nomor 10 Tahun 2004 adalah sebagai berikut :

1) UUD Negara Republik Indonesia Tahun 1945

2) UU / Peraturan Pemerintah pengganti Undang - Undang

3) Peraturan Pemerintah

4) Peraturan Presiden

5) Peraturan Daerah

Berikut adalah macam-macam hierarki tujuan pendidikan, yaitu :

1. Tujuan Pendidikan Nasional, membentuk manusia pembangunan sehat jasmani dan rohaninya, memiliki pengetahuan dan keterampilan. dapat mengembangkan kreativitas dan tanggung jawab, dapat menyuburkan sikap demokrasi dan penuh tenggang rasa, dapat mengembangkan kecerdasan yang tinggi dan disertai budi perkerti yang luhur, mencintai bangsanya dan sesama manusia dengan ketentuan yang termaktub dalam UUD 1945.

2. Tujuan Institusional, Tujuan yang hendak dicapai oleh setiap jenjang pendidikan, misalnya tujuan institusional SD, SMP, SMA, dan seterusnya. Semua tujuan berorientasi pada pencapaian tujuan nasional, dan agar setiap tujuan tidak menyimpang maka perlu didahului dengan pengertian pendidikan, dasar pendidikan, dan tujuan pendidikan nasional.

3. Tujuan Kurikuler, tujuan yang hendak dicapai oleh mata pelajaran tertentu. Berupa pengalaman-pengalaman belajar siswa sesuai mata pelajaran yang diikuti dan harus sesuai dengan tujuan institusional dan tujuan nasional. Misal tujuan pelajaran olahraga dan kesehatan, untuk menjadikan siswa sehat jasmani dan rohani.

4. Tujuan Instruksional, tujuan yang hendak dicapai pada saat pelajaran berlangsung. Tujuan ini dibedakan atas tujuan Instruksional umum dan tujuan Intruksional khusus. Tujuan Instruksional Umum (TIU) sesudah dirumuskan dan merupakan acuan dalam perumusan tujuan intruksional

\footnotetext{
${ }^{8}$ http://komunitasgurupkn.blogspot.co.id/2017/01/tata-urutan-peraturan-perundang.html?m=1
} 
khusus. Tujuan Intruksional Khusus (TIK) merupakan penanda terjadinya perubahan tingkah laku pada anak setelah mengikuti pelajaran tertentu. ${ }^{9}$

\section{Informasi pendukung}

- http://shoutsscience.blogspot.co.id/2016/08/hierarki-perundangundangan-republik.html?m=1

- http://sekilaspendidik.blogspot.co.id/2013/03/peraturan-perundangundangan.html

- https://rudini76ban.wordpress.com/2009/03/21/fungsi-peraturanperundang-undangan/

- http://imajinasichepyo.blogspot.co.id/2013/04/dasar-fungsi-dan-tujuanpendidikan.html

- http://komunitasgurupkn.blogspot.co.id/2017/01/tata-urutan-peraturanperundang.html?m=1

- Kumpulan peraturan perundangan

\section{Latihan-latihan}

1) Apa yang dimaksud dengan Peraturan Perundang-undangan?

2) Seseorang yang melanggar peraturan dan undang-undang akan dikenai sanksi atau hukuman, hukuman tersebut dapat berupa?

3) Apa yang dimaksud dengan Hierarki dan mengapa harus ada Hierarki?

4) Sebutkan jenis dan hierarki peraturan perundang-undangan di Indonesia!

5) Sebutkanlah macam-macam Hierarki tujuan pendidikan!

\section{Petunjuk kerja, dapat berupa Lembar Kerja (LK)}

Untuk dapat menjawab pertanyaan nomor 4 Anda harus mencari dan membaca UU No. 10 Tahun 2004 tentang pembentukan peraturan perundangundangan.

\section{Evaluasi}

Jawablah pertanyaan dibawah ini dengan benar untuk setiap pertanyaan dibawah ini diberikan bobot masing-masing seperti dalam soal.

1) Seperangkat ketetapan yang diperlukan agar ada efisiensi dalam usaha mengejar sebuah tujuan disebut...

a. Peraturan

\footnotetext{
${ }^{9}$ http://shoutsscience.blogspot.co.id/2016/08/hierarki-perundang-undangan-republik.html?m=1
} 

b. Pembagian
c. Penyusunan
d. Pembentukan
e. perencanaan

2) Tujuan undang-undang dan peraturan negara adalah...
a. Untuk mengatur
b. Untuk diaksanakan
c. Untuk mengatur dan menertibkan setiap kehidupan berbangsa dan bernegara
d. Untuk membentuk negara menjadi lebih baik
e. Untuk menjadikan kehidupan warga negara lebih tertib

3) Secara umum peraturan perundang-undangan fungsinya adalah...
a. Membantu
b. Mengawasi
c. Mengesahkan
d. Merubah
e. Mengatur

4) Sebutkan macam-macam Hierarki Tujuan Pendidikan, kecuali...
a. Tujuan Yuridis
b. Tujuan Pendidikan Nasional
c. Tujuan Institusional
d. Tujuan Kurikuler
e. Tujuan Instruksional

5) Diantara hukuman di bawah ini manakah yang bukan hukuman bagi orang yang melanggar peraturan dan undang undang ....
a. Penjara 5 tahun
b. Membuat undang - undang baru
c. Penjara dan dikenai denda
d. Di rajam
e. Tidak di akui sebagai warga negara

6) Berikut isi Undang-Undang 20/2003, pasal 4, kecuali..

a. Pendidikan diselenggarakan sebagai satu kesatuan yang sistemik dengan sistem terbuka dan multimakna. 
b. Pendidikan diselenggarakan sebagai suatu proses pembudayaan dan pemberdayaan peserta didik yang berlangsung sepanjang hayat.

c. Pendidikan diselenggarakan dengan mengembangkan budaya membaca, menulis dan berhitung bagi segenap warga masyarakat.

d. Pendidkan diselenggarakan dengan memberdayakan semua komponen masyarakat melalui peran serta dalam penyelenggaraan dan pengendalian mutu layanan pendidikan.

e. Pendidikan tidak diselenggarakan sebagai suatu proses pembudayaan dan pemberdayaan peserta didik yang berlangsung sepanjang hayat.

7) Ada berapakah macam-macam Hierarki Tujuan Pendidikan

a. 4 macam

b. 3 macam

c. 2 macam

d. 6 macam

e. 5 macam

8) Apa tujuan Instruksional dalam hierarki peraturan pendidikan..

a. Untuk dicapai pada saat pelajaran berlangsung

b. Untuk membentuk manusia pembangunan sehat jasmani dan rohaninya, memiliki pengetahuan dan keterampilan.

c. Bertujuan untuk dicapai oleh mata pelajaran tertentu

d. Untuk mencintai bangsanya dan sesama manusia dengan ketentuan yang termaktub dalam UUD 1945.

e. Untuk diikuti dan harus sesuai dengan tujuan institusional

9) Apa fungsi PUUP yang utama...

a. Menjadiakan negara teratur

b. Membatasi dan membagi kewenangan para penyelenggara pemerintahan negara, sehingga dapat tercipta keterkendalian dan keseimbangan.

c. Tidak Membatasi dan membagi kewenangan para penyelenggara pemerintahan negara, sehingga dapat tercipta keterkendalian dan keseimbangan

d. Menjadikan negara yang tidak berpriaku baik

e. Memecahkan masalah yang ada pada negara 
10) Dalam Tab mpr no.III/mpr/2000 tentang sumber hukum dan tata urutan peraturan undang - undang, terdapat urutan peraturan perundangundangan RI , kecuali...
a. UUD 1945
b. Peraturan pemerintah pengganti UU
c. Peraturan daerah
d. Keputusan presiden
e. Keppres

\section{Respon atau balikan terhadap hasil evaluasi}

Setiap item jawaban yang benar diberikan nilai 10,bila Anda belum mencapai $80 \%$ untuk nilai yang diperoleh silahkan baca ulang dengan teliti dan baik, kemudian kerjakan soal diatas.

Keterangan

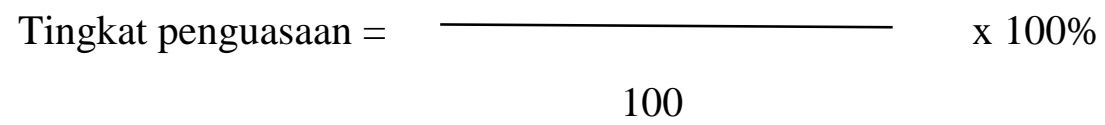

Arti tingkat penguasaan anda:

$$
\begin{array}{ll}
90 \%-100 \% & =\text { baik sekali } \\
80 \%-89 \% & =\text { baik } \\
70 \%-79 \% & =\text { cukup } \\
<70 \% & =\text { kurang }
\end{array}
$$

\section{JAWABAN LATIHAN-LATIHAN}

1) Peraturan Perundang-undangan adalah peraturan tertulis yang dibentuk oleh lembaga negara atau pejabat yang berwenang dan mempunyai kekutan yang mengikat.

2) Hukuman itu dapat berupa denda atau pun kurungan penjara.

3) Hierarki adalah peraturan perundang-undangan yang lebih rendah tidak boleh bertentangan dengan peraturan perundang-undangan yang lebih tinggi. Karena hierarki dimaksudkan agar suatu peraturan perundang-undangan yang lebih rendah tidak boleh bertentangan dengan peraturan yang lebih tinggi. 
4) Hierarki Peraturan perundang-undangan di Indonesia menurut UU No. 10/2004 tentang pembentukan peraturan perundang-undangan : UUD 1945 merupakan hukum dasar dalam peraturan perundang-undangan. UUD 1945 ditempatkan dalam Lembaga Negara Republik Indonesia; UU/Peraturan Pemerintah Pengganti Undang-Undang (Perpu); Peraturan Pemerintah (PP), Peraturan Presiden (Perpres); Peraturan Daerah (Perda); termasuk pula Qanun yang berlaku di Nanggroe Aceh Darussalam, serta Perdasus dan Perdasi yang berlaku di Provinsi Papua dan Papua Barat. Dari Peraturan Perundang-Undangan tersebut, aturan yang mengenai ketentuan pidana hanya dapat dimuat dalam Undang-Undang dan Peraturan Daerah.

5) - Tujuan Pendidikan Nasional

- Tujuan Institusional

- Tujuan Kurikuler

- Tujuan Instruksional

JAWABAN EVALUASI
1) $\mathrm{A}$
6) $\mathrm{E}$
2) $\mathrm{C}$
7) $\mathrm{A}$
3) $\mathrm{E}$
8) A
4) $\mathrm{A}$
9) $\mathrm{B}$
5) $\mathrm{C}$
10) $\mathrm{D}$ 


\section{BAB VI}

\section{PROSEDUR PENYUSUNAN PUUP}

\section{Pokok Bahasan :}

Prosedur penyusunan PUUP

\section{Kompetensi yang akan tercapai}

Pemahaman tentang alur dan tingkatan dalam penyusunan peraturan perundangan pendidikan

\section{Petunjuk belajar}

- Baca basmallah untuk memulainya.

- Baca dengan seksama setiap penjelasan yang ada dalam bagian materi.

- Perhatikan penjelasan dosen pada saat dosen sedang menerangkan/menjelaskan.

- Buat rangkuman

- Kerjakan dengan baik soal-soal latihan yang ada.

\section{Konten atau isi materi pembelajaran}

\section{A. Pengertian Prosedur}

Prosedur adalah serangkaian aksi yang spesifik, tindakan atau operasi yang harus dijalankan atau dieksekusi dengan cara yang baku (sama) agar selalu memperoleh hasil yang sama dari keadaan yang sama, semisal prosedur kesehatan dan keselamatan kerja.

Lebih tepatnya, kata ini bisa mengindikasikan rangkaian aktivitas, tugas-tugas, langkah-langkah, keputusan-keputusan, perhitungan-perhitungan dan proses-proses, yang dijalankan melalui serangkaian pekerjaan yang menghasilkan suatu tujuan yang diinginkan, suatu produk atau sebuah akibat. Sebuah prosedur biasanya mengakibatkan sebuah perubahan. ${ }^{10}$

\section{Pengertian prosedur menurut para ahli:}

1. Menurut Mulyadi (2010:5) prosedur adalah suatu kegiatan klerikal, biasanya melibatkan beberapa orang dalam suatu department atau lebih, yang dibuat untuk menjamin penanganan secara seragam transaksi perusahaan yang terjadi berulang-ulang."

\footnotetext{
${ }^{10} \mathrm{https}: / /$ id.wikipedia.org/wiki/Prosedur
} 
2. Menurut Zaki Baridwan (2009:30) prosedur merupakan suatu urutanurutan pekerjaan kerani (clerical), biasanya melibatkan beberapa orang dalam suatu bagian atau lebih, disusun untuk menjamin adanya perlakuan yang seragam terhadap transaksi-transaksi perusahaan yang sedang terjadi. $^{11}$

\section{B. Pengertian Penyusunan}

Arti dari penyusunan adalah: pe.nyu.sun.an

Nomina (kata benda) proses, cara, perbuatan menyusun (seperti penyusunan kamus, ensiklopedia) ${ }^{12}$

\section{Peraturan Perundang-Undangan Pendidikan}

Peraturan perundangan-undangan berbeda dengan Undang-Undang, karena Undang-Undang hanya merupakan salah satu bagian dari peraturan perundang-undangan. Peraturan Peundang-Undangan itu sendiri adalah semua pertauran tertulis yang dibentuk dengan cara-cara tertentu oleh pejabat yang berwenang dan dituangkan dalam bentuk tertulis.

Menurut Undang-Undang No 12 Tahun 2011 tentang Pembentukan Peraturan Perundang-Undangan, dinyatakan bahwa Peraturan Perundangundangan adalah peraturan tertulis yang memuat norma hukum yang mengikat secara umum dan dibentuk atau ditetapkan oleh lembaga negara atau pejabat yang berwenang melalui prosedur yang ditetapkan dalam Peraturan Perundang-undangan.

Dalam kehidupan berbangsa dan bernegara, fungsi peraturan perundangundangan, antara lain sebagai berikut:

a) sebagai norma hukum bagi warga negara karena beisi peraturan untuk membatasi tingkah laku manusia sebagai warga negara yang harus ditaati, dipatuhi, dan dilaksanakan. Bagi mereka yang melanggar diberi sanksi atau hukum sesuai dengan ketentuan yang berlaku, sehingga terjamin rasa keadilan dan kebenaran.

${ }^{11} \mathrm{http} / / /$ cokinew.blogspot.co.id/2016/02/pengertian-prosedur-menurut-para-ahli.html 
b) Menentukan aturan-aturan yang menjadi pedoman dalam menjalankan hubungan antar sesama manusia sebabagi warga negara dan warga masyarakat

c) untuk mengatur kehidupan manusia sebagai warga negara agar kehidupannya sejahtera. aman, rukun, dan harmonis;

d) untuk menciptakan suasana aman, tertib, tenteram dan kehidupan yang harmonis rasa.

e) untuk memberikan rasa keadilan dan kepastian hukum bagi warga negara.

f) untuk memberikan perlindungan atas hak asasi manusia. ${ }^{13}$

\section{1) UU NO 20 Tahun 2003 tentang Sistem Pendidikan Nasional}

Dalam UU ini penyelenggaraan pendidikan wajib memegang beberapa prinsip, yakni pendidikan diselenggarakan secara demokratis dan berkeadilan serta tidak diskriminatif dengan menjunjung tinggi hak asasi manusia, nilai keagamaan, nilai kultural, dan kemajemukan bangsa dengan satu kesatuan yang sistemik dengan sistem terbuka dan multimakna. Selain itu dalam penyelenggaraan juga harus dalam suatu proses pembudayaan dan pemberdayaan peserta didik yang berlangsung sepanjang hayat dengan memberi keteladanan, membangun kemauan, dan mengembangkan kreativitas peserta didik dalam proses pembelajaran melalui mengembangkan budaya membaca, menulis, dan berhitung bagi segenap warga masyarakat memberdayakan semua komponen masyarakat melalui peran serta dalam penyelenggaraan dan pengendalian mutu layanan pendidikan. ${ }^{14}$

\section{2) PP NO. 19 Tahun 2005 tentang Standart Pendidikan Nasional (SNP)} Lingkup Standar Nasional Pendidikan

1. Standar Nasional Pendidikan (SNP) adalah kriteria minimal tentang sistem pendidikan di seluruh wilayah hukum Negara Kesatuan

\footnotetext{
${ }^{13} \mathrm{http}$ ://ainamulyana.blogspot.com/2016/08/tata-urutan-peraturan-perundang.html http://referensi.elsam.or.id/2014/11/uu-nomor-20-tahun-2003-tentang-sistempendidikan-nasional/
} 
Republik Indonesia. Standar Nasional Pendidikan ada agar kinerja dari elemen pokok pembentuk kinerja itu berhasil. Elemen meliputi input, proses, dan keluaran. Lingkup Standar Nasional Pendidikan meliputi:

- Standar isi adalah ruang lingkup materi dan tingkat kompetensi yang dituangkan dalam kriteria tentang kompetensi tamatan, kompetensi bahan kajian, kompetensi mata pelajaran, dan silabus pembelajaran yang harus dipenuhi oleh peserta didik pada jenjang dan jenis pendidikan tertentu.

- Standar proses adalah standar nasional pendidikan yang berkaitan dengan pelaksanaan pembelajaran pada satu satuan pendidikan untuk mencapai standar kompetensi lulusan. Proses pembelajaran pada satuan pendidikan diselenggarakan secara interaktif, inspiratif, menyenangkan, menantang, memotivasi peserta didik untuk berpartisipasi aktif, serta memberikan ruang yang cukup bagi prakarsa, kreativitas, dan kemandirian sesuai dengan bakat, minat, dan perkembangan fisik serta psikologis peserta didik.

- Standar kompetensi lulusan adalah kualifikasi kemampuan lulusan yang mencakup sikap, pengetahuan, dan keterampilan.

- Standar pendidik dan tenaga kependidikan adalah kriteria pendidikan prajabatan dan kelayakan fisik maupun mental, serta pendidikan dalam jabatan. Pendidik harus memiliki kualifikasi akademik dan kompetensi sebagai agen pembelajaran, sehat jasmani dan rohani, serta memiliki kemampuan untuk mewujudkan tujuan pendidikan nasional. Kualifikasi akademik yang dimaksudkan adalah tingkat pendidikan minimal yang harus dipenuhi oleh seorang pendidik yang dibuktikan dengan ijazah dan/atau sertifikat keahlian yang relevan sesuai ketentuan perundang-undangan yang berlaku. Kompetensi sebagai agen pembelajaran pada jenjang pendidikan dasar dan menengah serta pendidikan anak usia dini meliputi:Kompetensi pedagogik;Kompetensi kepribadian;Kompetensi profesional; danKompetensi sosial. 
- standar sarana dan prasarana adalah standar nasional pendidikan yang berkaitan dengan kriteria minimal tentang ruang belajar, tempat berolahraga, tempat beribadah, perpustakaan, laboratorium, bengkel kerja, tempat bermain, tempat berkreasi dan berekreasi, serta sumber belajar lain, yang diperlukan untuk menunjang proses pembelajaran, termasuk penggunaan teknologi informasi dan komunikasi.

- Standar pengelolaan adalah standar nasional pendidikan yang berkaitan dengan perencanaan, pelaksanaan, dan pengawasan kegiatan pendidikan pada tingkat satuan pendidikan, kabupaten/kota, provinsi, atau nasional agar tercapai efisiensi dan efektivitas penyelenggaraan pendidikan.

- Standar pembiayaan adalah standar yang mengatur komponen dan besarnya biaya operasi satuan pendidikan yang berlaku selama satu tahun. Pembiayaan pendidikan terdiri atas:Biaya investasi satuan pendidikan meliputi biaya penyediaan sarana dan prasarana, pengembangan sumberdaya manusia, dan modal kerja tetap.Biaya personal sebagaimana dimaksud pada di atas meliputi biaya pendidikan yang harus dikeluarkan oleh peserta didik untuk bisa mengikuti proses pembelajaran secara teratur dan berkelanjutan.Biaya operasi satuan pendidikan meliputi: Gaji pendidik dan tenaga kependidikan serta segala tunjangan yang melekat pada gaji, Bahan atau peralatan pendidikan habis pakai, dan Biaya operasi pendidikan tak langsung berupa daya, air, jasa telekomunikasi, pemeliharaan sarana dan prasarana, uang lembur, transportasi, konsumsi, pajak, asuransi, dan lain sebagainya.

- Standar penilaian pendidikan adalah standar nasional pendidikan yang berkaitan dengan mekanisme, prosedur, dan instrumen penilaian hasil belajar peserta didik. ${ }^{15}$

\section{3) UU NO 14 Tahun 2005 tentang Guru dan Dosen}

\footnotetext{
${ }^{15}$ http://herysusantolimpung.blogspot.co.id/2012/03/v-behaviorurldefaultvmlo.html
} 
a. bahwa pembangunan nasional dalam bidang pendidikan adalah upaya mencerdaskan kehidupan bangsa dan meningkatkan kualitas manusia Indonesia yang beriman, bertakwa, dan berakhlak mulia serta menguasai ilmu pengetahuan, teknologi, dan seni dalam mewujudkan masyarakat yang maju, adil, makmur, dan beradab berdasarkan Pancasila dan Undang-Undang Dasar Negara Republik Indonesia Tahun 1945;

b. bahwa untuk menjamin perluasan dan pemerataan akses, peningkatan mutu dan relevansi, serta tata pemerintahan yang baik dan akuntabilitas pendidikan yang mampu menghadapi tantangan sesuai dengan tuntutan perubahan kehidupan lokal, nasional, dan global perlu dilakukan pemberdayaan dan peningkatan mutu guru dan dosen secara terencana, terarah, dan berkesinambungan;

c. bahwa guru dan dosen mempunyai fungsi, peran, dan kedudukan yang sangat strategis dalam pembangunan nasional dalam bidang pendidikan sebagaimana dimaksud pada huruf a sehingga perlu dikembangkan sebagai profesi yang bermartabat;

d. bahwa berdasarkan pertimbangan sebagaimana dimaksud pada huruf $a$, huruf $b$, dan huruf c perlu dibentuk Undang-Undang tentang Guru dan Dosen. ${ }^{16}$

\section{4) PP No 17 Tahun 2010 tentang Pengelolaan dan Penyelenggaraan Pendidikan}

Sebagai penjabaran dari Undang-Undang Nomor 20 Tahun 2003 tentang Sistem Pendidikan Nasional, pemerintah telah menerbitkan regulasi baru yaitu Peraturan Pemerintah Nomor 17 Tahun 2010 tentang Pengelolaan dan Penyelenggaraan Pendidikan.

Peraturan ini terdiri dari XVIII Bab dan 222 pasal beserta penjelasannya, Peraturan ini ditandangani oleh Presiden Republik Indonesia, DR. H. Susilo Bambang Yudhoyono, dan diundangkan oleh Menhunkam Patralis Akbar pada tanggal 28 Januari 2010 di Jakarta. ${ }^{17}$

\footnotetext{
${ }^{16} \mathrm{http} / / /$ www.sjdih.depkeu.go.id/fullText/2005/14TAHUN2005UU.htm

${ }^{17} \mathrm{https}$ ://akhmadsudrajat.wordpress.com/2010/04/14/download-peraturan-pemerintahnomor-17-tahun-2010-tentang-pengelolaan-dan-penyelenggaraan-pendidikan/
} 


\section{Prosedur Penyusunan Peraturan Perundang-Undangan Pendidikan}

Proses atau perumusan peraturan perundangan meliputi tiga tahap. Ketiga tahap itu adalah tahap inisiasi, tahap sosio-politis, dan tahap yuridis. Namun, langkah-langkah berikut ini hanya berlaku untuk proses pembuatan undang-undang, tidak mencakup semua peraturan perundangan. Berikut dijelaskan tahap-tahap tersebut.

\section{1) Tahap Inisiasi}

Dimulai dengan munculnya gagasan atau ide dari masyarakat. Ide itu berhubungan keinginan agar suatu masalah diatur oleh hukumdalam peraturan perundang-undangan. Misalnya, masyarakat menginginkan adanya peraturan tentang judi, pornoaksi, dan pornografi agar dapat membuat ketertiban serta moral masyarakat terlindungi.

\section{2) Tahap Sosio-Politis}

Di dalam tahap pengelolaan gagasan tentang perlunya pengaturan hukum dari masalah tertentu harus dimulai dari menampung gagasan dari berbagai sumber. Kemudian, disiapkan materi dari isi hukum. Setelah itu, rancangan tersebut dibicarakan, dikritisi, dan dipertahankan melalui silang pendapat antara unsur golongan, kelompok, organisasi, dan kekuatan politis dalam masyarakat. Kemudian, bahan-bahan materi perundangundangan ini dipertajam dan dimatangkan oleh lembaga pemerintah.

\section{3) Tahap Yuridis}

Tahap ini adalah tahap yang murni muatan yuridisnya, yaitu perumusan dalam bahasa hukum. Tahapan ini dilakukan oleh lembaga yang berwenang, bergantung pada tingkat perundang-undangan tersebut. Misalnya, berdasarkan ketentuan UUD 1945 Pasal 5 Ayat 1, Pasal 20, dan Pasal 21 bahwa rancangan undang-undang berasal dari presiden atau DPR.

Alur proses penyusunan peraturan perundang-undangan ini lebih lanjut diatur oleh undang-undang. Undang-undang yang dimaksud adalah UU No. 10 Tahun 2004. Rancangan undang-undang dapat disiapkan oleh 
presiden dan dapat juga disiapkan oleh DPR. Lembaga tersebut mempunyai alur penyusunan peraturan perundang-undangan tersendiri.

a) Usulan Rancangan Undang-Undang dari presiden melalui tahap-tahap sebagai berikut.

1) Usulan dari menteri atau lembaga nondepartemen, mencakup rumusan hukum yang dilengkapi dengan penjelasan tentang halhal sebagai berikut:
a. Latar belakang, tujuan, dan sasaran yang ingin dicapai.
b. Pokok-pokok pikiran, ruang lingkup, dan objek dari undang- undang.
c. Jangkauan dan arah pengaturan.

2) Pembahasan oleh Menteri Kehakiman bekerja sama dengan perguruan tinggi atau pihak ketiga menghasilkan rancangan akademis tentang RUU, yaitu melalui tahap-tahap kegiatan sebagai berikut:
a. Pengharmonisasian.
b. Pembuatan.
c. Pemantapan

3) Diserahkan kepada Presiden dengan memberikan arahan sebagai berikut.
a. Sifat penyelesaian RUU.
b. Cara pembahasan, jika RUU lebih dari satu.
c. Menteri ditugaskan untuk membahas di DPR.

4) Presiden menyerahkan kepada DPR untuk dibahas. Pembahasan di DPR melalui tahap-tahap sebagai berikut:
a. Tingkat I dalam Rapat Paripuna. Pemberian penjelasan oleh pemerintah/menteri terkait.
b. Tingkat II dalam Rapat Paripurna. Pemandangan umum dari fraksi-fraksi di DPR atas RUU dan penjelasan pemerintah.
c. Tingkat III dalam rapat Komisi, Gabungan Komisi, atau Rapat panita Khusus bersama pemerintah.
d. Tingkat IV dalam Rapat Paripurna. Laporan hasil pembicaraan Tingkat III, pendapat akhir fraksi, pengambilan keputusan, dan sambutan oleh pemerintah.


5) Pengesahan oleh presiden menjadi undang-undang dan diumumkan oleh Lembaran Negara.

a. Pimpinan DPR menyerahkan Rancangan UndangUndang kepada presiden.

b. Presiden menunjuk menteri yang akan mewakili pemerintah dalam pembahasan bersama DPR.

b) Usulan Rancangan Undang-Undang dari DPR melalui tahap-tahap sebagai berikut.

1) Diusulkan oleh minimal sepuluh anggota dari gabungan fraksi yang berbeda dengan tahap-tahap sebagai berikut:

a. Rancangan usul disampaikan secara tertulis kepada pimpinan dewan disertai pengantar yang memuat daftar nama pengusul dan asal fraksinya.

b. Pimpinan membawa rancangan ke rapat paripurna untuk memberi tahu kepada semua anggota.

c. Draf naskah dibagikan kepada para anggota DPR.

2) Rapat Badan Musyawarah Dewan Perwakilan Rakyat.

a. Diadakan tanya jawab, di antara anggota Badan Musyawarah.

b. Pewakilan para pengusul memberi penjelasan seperlunya.

3) Rapat Paripurna DPR.

a. Pengusul memberikan penjelasan.

b. Tanggapan umum dari setiap fraksi.

c. Pembahasan disetujui atau tidaknya RUU.

d. Jika disetujui dilanjutkan ke tahap berikutnya, dan jika ditolak berarti dihentikan sampai di sini.

4) Menunjuk komisi atau rapat gabungan komisi atau pansus

a. Membahas dan menyempurnakan Rancangan UndangUndang.

b. Secara teknis administratif dibantu oleh sekretariat DPR.

5) Menyerahkan kepada presiden

a. Pimpinan DPR menyerahkan Rancangan UndangUndang kepada presiden. 
b. Presiden diminta menunjuk menteri yang akan mewakili pemerintah dalam pembahasan bersama DPR.

6) Pembahasan DPR bersama pemerintah

a. Tingkat I dalam rapat paripurna. Pemberian penjelasan oleh pimpinan komisi, gabungan komisi atau pansus.

b. Tingkat II dalam rapat paripurna. Tanggapan pemerintah atas rancangan undang-undang, penjelasan komisi, dan jawaban pimpinan komisi terhadap tanggapan pemerintah.

c. Tingkat III dalam rapat komisi, gabungan komisi, atau rapat panitia khusus bersama pemerintah.

d. Tingkat IV dalam rapat paripurna. Laporan hasil pembicaraan tingkat III, pendapat akhir fraksi, pengambilan keputusan, dan sambutan oleh pemerintah.

7) Pengesahan oleh presiden menjadi undang-undang dan pengumuman dalam Lembaran Negara. ${ }^{18}$

\section{E. Asas Pembentukan Peraturan Perundang-Undangan}

\section{Asas Formil}

Asas formil dalam pembentukan Peraturan Perundang-undangan yang baik yaitu meliputi:

a. Kejelasan tujuan, yaitu setiap pembentukan Peraturan PerundangUndangan harus mempunyai tujuan dan manfaat yang jelas untuk apa dibuat;

b. Kelembagaan atau organ pembentuk yang tepat, yaitu setiap jenis Peraturan Perundang-undangan harus dibuat oleh lembaga atau organ pembentuk Peraturan Perundang-undangan tersebut dapat dibatalkan atau batal demi hukum, apabila dibuat oleh lembaga atau organ yang tidak berwenang;

18 http://pendidikan60detik.blogspot.co.id/2015/11/proses-pembuatan-peraturanperundangan.html 
c. Kesesuaian antara jenis dan materi muatan, yaitu perumusan materi muatan dalam setiap Peraturan Perundang-undangan harus memiliki kesesuaian dengan;

d. Dapat dilaksanakan, yaitu setiap pembentukan Peraturan Perundangundangan harus didasarkan pada perhitungan bahwa Peraturan Perundang-undangan yang dibentuk nantinya dapat berlaku secara efektif di masyarakat karena telah mendapat dukungan baik secara filosofis, yuridis maupun sosiologis sejak tahap penyusunannya;

e. Kedayagunaan dan kehasilgunaan, yaitu setiap Peraturan Perundangundangan yang dibentuk benar-benar mempunyai dayaguna dan hasil guna berlaku di dalam masyarakat, berfungsi secara efektif dalam memberikan ketertiban, ketenteraman, dan kedamaian bagi masyarakat

f. Kejelasan rumusan yaitu bahwa setiap Peraturan Perundang-undangan harus memenuhi persyaratan teknis penyusunan Peraturan Perundangundangan, sistematika, dan pilihan kata atau terminologi, serta bahasa hukumnya jelas dan mudah dimengerti, sehingga tidak menimbulkan berbagai macam interprestasi dalam pelaksanaannya;

g. Keterbukaan, yaitu tidak adanya muatan materi Peraturan Perundangundangan yang disembunyikan atau bersifat semu, sehingga dapat menimbulkan berbagai penafsiran dalam praktek/implementasinya.

\section{Asas Materiil}

Materi Peraturan Perundang-undangan mengandung asas:

a. Pengayoman, yaitu setiap Peraturan Perundang-undangan harus berfungsi mengayomi seluruh masyarakat dan memberikan perlindungan hak asasi manusia yang hakiki;

b. Kemanusiaan, yaitu setiap Peraturan Perundang-undangan harus bersifat manusiawi dan menghargai harkat dan martabat manusia serta tidak boleh membebani masyarakat di luar kemampuan masyarakat itu sendiri;

c. Kebangsaan, yaitu setiap Peraturan Perundang-undangan harus mencerminkan sifat dan watak bangsa Indonesia yang berasaskan musyawarah dalam mengambil keputusan; 
d. Kekeluargaan, yaitu setiap Peraturan Perundang-Undangan harus mencerminkan asas musyawarah mufakat dalam setiap penyelesaian masalah yang diatur dalam Peraturan Perundang-undangan;

e. Kenusantaraan, yaitu setiap Peraturan Perundang-undangan merupakan bagian dari sistem hukum nasional yang berdasarkan Pancasila atau wilayah/daerah tertentu, sesuai dengan jenis Peraturan Perundangundangan tersebut;

f. Kebhinnekatunggalikaan, yaitu setiap perencanaan, pembuatan, dan penyusunan serta materi muatan Peraturan Perundang-Undangan harus memperhatikan keragaman penduduk, agama, suku, dan golongan khususnya yang menyangkut masalah-masalah yang sensitif dalam kehidupan bermasyarakat, berbangsa, dan bernegara;

g. Keadilan yang merata, yaitu setiap Peraturan Perundang-Undangan harus mencerminkan keadilan bagi setiap warga negara tanpa kecuali;

h. Kesamaan kedudukan dalam hukum dan pemerintahan, yaitu setiap Peraturan Perundang-undangan materi muatannya tidak boleh berisi hal-hal yang bersifat diskriminatif;

i. Ketertiban dan kepastian hukum; yaitu setiap Peraturan PerundangUndangan harus dapat menimbulkan kepastian hukum dan ketertiban dalam masyarakat;

j. Keseimbangan, keserasian, dan keselarasan, yaitu setiap Peraturan Perundang-undangan materi muatannya atau isinya harus mencerminkan keseimbangan, keserasian, dan keselarasan antara kepentingan individu dan masyarakat, serta bangsa dan negara. ${ }^{19}$

\section{F. Asas Pemberlakuan Peraturan Perundang-undangan}

Secara umum ada beberapa asas atau dasar agar supaya Peraturan Perundang-undangan berlaku dengan baik dan efektif, dalam arti bahwa Peraturan Perundangundangan tersebut berlaku dengan baik (sempurna) dan efektif dalam teknik penyusunannya. Ada 3 (tiga) asas pemberlakuan Peraturan Perundang-Undangan yakni asas yuridis, asas filosofis, asas sosiologis. Teknik penyusunan Peraturan Perundang-Undangan merupakan

\footnotetext{
${ }^{19} \mathrm{https} / / /$ alisadikinwear.wordpress.com/2012/05/11/landasan-penyusunan-peraturanperundangan/
} 
hal lain yang tidak mempengaruhi keberlakuan Peraturan Perundangundangan, namun menyangkut baik atau tidaknya rumusan suatu Peraturan Perundang-undangan.

\section{Asas Yuridis}

Asas yuridis tersebut sangat penting artinya dalam penyusunan Peraturan Perundang-Undangan, yaitu yang berkaitan dengan :

- Keharusan adanya kewenangan dari pembuat Peraturan PerundangUndangan, yang berarti bahwa setiap Peraturan Perundang-undangan harus dibuat oleh badan atau pejabat yang berwenang.

- Keharusan adanya kesesuaian antara jenis dan materi muatan Peraturan Perundang-undangan. Ketidaksesuaian jenis tersebut dapat menjadi alasan untuk membatalkan Peraturan Perundang-undangan yang dibuat.

- Keharusan mengikuti tata cara atau prosedur tertentu. Apabila prosedur/tata cara tersebut tidak ditaati, maka Peraturan Perundangundangan tersebut batal demi hukum atau tidak/belum mempunyai kekuatan mengikat.

- Keharusan tidak bertentangan dengan Peraturan Perundang-undangan yang lebih tinggi tingkatannya.

\section{Asas Filosofis}

Asas filosofis Peraturan Perundang-undangan adalah dasar yang berkaitan dengan dasar filosofis/ideologi negara, dalam arti bahwa Peraturan Perundang-Undangan harus memperhatikan secara sungguhsungguh nilai-nilai (citra hukum) yang terkandung dalam Pancasila. Setiap masyarakat mengharapkan agar hukum itu dapat menciptakan keadilan, ketertiban, dan kesejahteraan.

\section{Asas Sosiologis}

Asas sosiologis Peraturan Perundang-undangan adalah dasar yang berkaitan dengan kondisi/kenyataan yang hidup dalam masyarakat berupa kebutuhan atau tuntutan yang dihadapi oleh masyarakat, kecenderungan dan harapan masyarakat. Oleh karena itu Peraturan Perundang-undangan 
yang telah dibuat diharapkan dapat diterima oleh masyarakat dan mempunyai daya-laku secara efektif. Peraturan Perundang-undangan yang diterima oleh masyarakat secara wajar akan mempunyai daya laku yang efektif dan tidak begitu banyak memerlukan pengarahan institusional untuk melaksanakannya. Soerjono Soekanto-Purnadi Purbacaraka mencatat dua landasan teoritis sebagai dasar sosiologis berlakunya suatu kaidah hukum, yaitu :

- Teori Kekuasaan (Machttheorie) secara sosiologis kaidah hukum berlaku karena paksaan penguasa, terlepas diterima atau tidak diterima oleh masyarakat;

- Teori Pengakuan, (Annerkenungstheorie). Kaidah hukum berlaku berdasarkan penerimaan dari masyarakat tempat hukum itu berlaku ${ }^{20}$

\section{A. SOAL PILIHAN GANDA}

1. Prosedur adalah suatu kegiatan klerikel, biasanya melibatkan beberapa orang dalam suatu departement atau lebih, merupakan pengertian prosedur menurut?
a. Lasswell
b. Soejono soekanto
c. Zaki baridwan (2009:30)
d. Mulyadi (2010:5)
e. Nimmo (1993:6)

2. Setiap Peraturan Perundang-undangan harus berfungsi mengayomi seluruh masyarakat dan memberikan perlindungan hak asasi manusia yang hakiki, merupakan pengertian dari?
a. Kekeluargaan
b. Kebangsaan
c. Kenusantaraan
d. kemanusiaan
e. Pengayoman

${ }^{20}$ http://arifin-zaenalarifin.blogspot.co.id/2013/06/legal-drafting-asas-asas-pemberlakuan.html 
3. Kaidah hukum berlaku berdasarkan penerimaan dari masyarakat tempat hukum itu berlaku, merupakan pengertian dari?
a. Teori perubahan
b. Teori Pengakuan
c. Teori perkembangan
d. Teori Kekuasaan
e. Teori pengembangan

4. Peraturan Pemerintah Nomor 17 Tahun 2010 tentang ...
a. Pengelolaan dan Penyelenggaraan Pendidikan.
b. Guru dan Dosen
c. Sistem Pendidikan Nasional
d. Standart Pendidikan Nasional
e. Perundang-undangan Pendidikan

5. UU NO 20 Tahun 2003 tentang ...
a. Pengelolaan dan Penyelenggaraan Pendidikan.
b. Guru dan Dosen
c. Sistem Pendidikan Nasional
d. Standart Pendidikan Nasional
e. Perundang-undangan Pendidikan

6. Masyarakat menginginkan adanya peraturan tentang judi, pornoaksi, dan pornografi agar dapat membuat ketertiban serta moral masyarakat terlindungi, hal tersebut merupan contoh dari tahap...
a. Tahap Sosio-politis
b. Tahap Inisiasi
c. Tahap Yuridis
d. Tahap Sosial
e. Tahap perkembangan

7. Pembahasan oleh Menteri Kehakiman bekerja sama dengan perguruan tinggi atau pihak ketiga menghasilkan rancangan akademis tentang RUU, yaitu melalui tahap-tahap kegiatan sebagai berikut:
1) Pengharmonisasian.
2) Penyusunan.
3) Pengelolaan
4) Pembuatan. 
5) Pemantapan.

Dari tahapan di atas manakah yang benar..
a. 1,2 , dan 3
b. 2,4 , dan 5
c. 1,3 , dan 4
d. 3,4 dan 5
e. Semua benar

8. Ada berapakah lingkup standar nasional pendidikan menurut PP No. 19 tahun 2005 tentang standart pendidikan nasional?
a. 5
b. 6
c. 7
d. 8
e. 9

9. UU NO 14 Tahun 2005 tentang
a. Pengelolaan dan Penyelenggaraan Pendidikan.
b. Guru dan Dosen
c. Sistem Pendidikan Nasional
d. Standart Pendidikan Nasional
e. Perundang-undangan Pendidikan

10. Proses atau perumusan peraturan perundang-undangan meliputi tahap berikut:
1) Tahap Sosio-politis
2) Tahap Inisiasi
3) Tahap Yuridis
4) Tahap Sosial
5) Tahap perkembangan

Dari tahap berikut manakah yang bener...
a. 1,2, dan 3 .
b. 2,3 , dan 4 .
c. 1,3 , dan 5
d. 2,4 , dan 5
e. 3, 4, dan 1

B. ESSAY 
1. Jelaskan pengertian prosedur!

Jawaban:

2. Jelaskan pengertian penyusunan!

Jawaban:

3. Apa perbedaan Peraturan Perundang-Undangan dengan Undang-Undang? Jawaban:

4. Sebutkan asas pemberlakuan Peraturan Perundang-undangan! Jawaban:

5. Sebutkan Perundang-undangan tentang pendidikan! Jawaban:

\section{JAWABAN}

A. PILIHAN GANDA
1. D
6. B
2. E
7. B
3. B
8. D
4. A
9. B
5. C
10. A

\section{B. ESSAI}

1. Prosedur adalah serangkaian aksi yang spesifik, tindakan atau operasi yang harus dijalankan atau dieksekusi dengan cara yang baku (sama) agar selalu memperoleh hasil yang sama dari keadaan yang sama, semisal prosedur kesehatan dan keselamatan kerja.

2. Penyusunan adalah Nomina (kata benda) proses, cara, perbuatan menyusun (seperti penyusunan kamus, ensiklopedia)

3. Peratutan Perundang-Undangan adalah sumua peraturan tertulis yang memuat norma hukum yang mengikat secara hukum yang mengikat secara umum dan dibentuk atau ditetapkan oleh lembaga negara atau pejabat yang berwenang melalui prosedur yang telah ditetapkan. Sedangkan, Undang-Undang merupakn salah satu jenis dari jenis peraturan Perundang-Undangan. 
4. 1. Asas Yuridis

2. Asas Filosofis

3. Asas Sosiologis

5. 1. UU NO 20 Tahun 2003 tentang Sistem Pendidikan Nasional

2. PP NO. 19 Tahun 2005 tentang Standart Pendidikan Nasional (SNP)

3. UU NO 14 Tahun 2005 tentang Guru dan Dosen

4. PP No 17 Tahun 2010 tentang pengelolaan dan penyelenggaraan pendidikan 


\section{BAB VII}

\section{PERUNDANG-UNDANGAN DAN KEBIJAKAN PEMERINTAH}

1. Pokok Bahasan

Perundang-undangan dan kebijakan pemerintah

2. Pencapaian kompetensi

Pemahaman tentang posisi perundang-undangan sebagai produk kebijakan

3. Petunjuk belajar

- Baca basmallah untuk memulainya

- Baca dengan seksama setiap penjelasan yang ada dalam bagian materi

- Perhatikan penjelasan dosen ada saat dosen menerangkanlmenjelaskan

- Buat rangkuman

- Kerjakan dengan baik soal-soal latihan yang ada

4. Perundang-undangan dan Kebijakan pemerintah dalam pendidikan

\section{A. Kebijakan Pemerintah dalam Pendidikan}

Kebijakan atau kebijaksanaan yang diterjemahkan dari kata policy memang biasanya dihubungkan dengan keputusan pemerintah, karena pemerintahlah yang mempunyai kekuasaan (wewenang) untuk mengarahkan masyarakat, dan bertanggung jawab melayani kepentingan umum. Kebijakan dapat juga berarti sebagai rangkaian konsep dan asas yang menjadi garis pelaksanaan suatu pekerjaan, kepemimpinan, dan cara bertindak.

Menurut Carl J. Friedrich mengatakan kebijakan pemerintah adalah suatu arah tindakan yang diusulkan pada seseorang, golongan, atau Pemerintah dalam suatu lingkungan dengan halangan-halangan dan kesempatan-kesempatannya, yang diharapkan dapat memenuhi dan mengatasi halangan tersebut di dalam rangka mencapai suatu cita-cita atau mewujudkan suatu kehendak serta suatu tujuan tertentu. (Soenarko, 2003:42). ${ }^{[1]}$ Pengertian kebijakan pendidikan (educational policy) sebagai suatu pertimbangan yang didasarkan atas sistem 
nilai dan beberapa penilaian atas faktor-faktor yang bersifat situasional, pertimbangan tersebut dijadikan sebagai dasar untuk mengopersikan pendidikan yang bersifat melembaga. ${ }^{[2]}$ Pendidikan merupakan salah satu faktor utama untuk dapat mencapai kemakmuran suatu Negara, sebagaimana diatur secara tegas dalam pasal 31 ayat (1) Undang-Undang Dasar 1945 (UUD 1945) yang menyatakan bahwa setiap warga Negara berhak mendapat pendidikan. Ayat (2) menegaskan bahwa setiap warga Negara wajib mengikuti pendidikan dasar dan pemerintah wajib membiayainya. Ayat (3) menetapkan bahwa pemerintah mengusahakan dan menyelenggarakan suatu sistem pendidikan nasional, yang meningkatkan keimanan dan ketaqwaan serta akhlak mulia dalam rangka mencerdaskan kehidupan bangsa, yang diatur dengan undang-undang. Dengan demikian, jelaslah bahwa Negara kita menempatkan pendidikan pada prioritas pertama dengan mengalokasikan anggaran terbesar dari semua sektor. Pendidikan merupakan sektor yang memang perlu diprioritaskan Negara karena menyentuh langsung hak masyarakat dan sangat terkait erat dengan pembangunan sumber daya manusia masa depan. ${ }^{[3]}$

Problematika di dunia pendidikan nampaknya selalu menjadi bahan bahasan yang tak akan pernah habis, mulai dari kondisi sekolah, peserta didik, dan pendidik sendiri. Hal ini tentu mengundang berbagai kebijkan yang harus sesuai dengan harapan masyarakat. Kebijakan pemerintah dalam pendidikan saat ini sangat dibutuhkan. Pemerintah pun nampak serius membenahi sistem pada dunia pendidikan yang bisa dilihat dari gelontoran anggaran pendidikan yang selalu ditambah. Hal ini pun langsung dirasakan warga pendidikan. Salah satu contohnya adalah dilaksanakannya kebijakan pemerintah didunia pendidikan dalam bentuk Bantuan Operasional Sekolah (BOS), bantuan bagi siswa tak mampu, pembangunan fisik gedung sekolah, hingga tunjangan sertifikasi bagi para guru, dan masih lagi kebijakan pemerintah lainnya dalam dunia pendidikan. Namun ada yang jarang sekali terdengar terkait banyaknya anak-anak Indonesia yang mempunyai kecerdasan istimewa yang secara alamiah tak bisa disamakan dengan anak-anak biasanya. Tentunya ini membawa problem tersendiri dalam dunia pendidikan.

Lantas seperti apakah kebijakan pemerintah dalam menangani anak-anak yang super cerdas ini sehingga keberadannya mendapat tempat yang sesuai dengan keberlangsungan mereka sebagai aset Negara. Maka dari itu diperlukan 
pendidikan khusus. Salah satunya dalam hal perekrutan dan angka standard pada test IQ. Terkait khusus dengan masalah mengenai test IQ, pemerintah menetapkan angka skala minimal menurut para psikologi yakni 130 dimana anak berada pada tingkatan very superior. Salah satu wacana kebijakan pemerintah dalam pendidikan adalah penerapan sistem SKS. Disekolah menengah pertama maupun atas mulai membahana. Wacana ini sudah pernah di dengungkan sebelumnya ditahun 2005, dan diklaim sesuai dengan amanah UU No. 20 tahun 2003 tentang sistem pendidikan nasional pasal 12 ayat 1 dan 2 .

Sekilas, wacana SKS ini kelihatan inovatif, karena dinilai mampu menambah kekayaan pengelolaan pembelajaran yang selama ini hanya menggunakan satusatunya cara, yaitu sistem paket atau, seperti yang termaksud di panduan SKS di sekolah menengah yang Badan Standar Nasional Pendidikan (BSNP), bahwa penerapan SKS ini dimungkinkan peserta didik dapat menyelesaikan program pendidikannya lebih cepat sesuai dengan kemampuan, bakat, dan minatnya.

Sayangnya niat untuk menerapkan SKS tersebut terkesan kurang dikaji secara sistemik. Tidak melihat taraf kompetensi guru yang ada selama ini secara umum, tidak melihat bagaimana tipe-tipe orang tua terhadap pendidikan anaknya, tidak melihat perkembangan psikologis siswa dan juga tidak melihat sisi metode pembelajaran seperti apa yang sesuai dengan usia peserta didik. Sehingga, tampaknya teori mekanisme dan hakikat praktek transfer ilmu yang selama ini dipahami untuk anak usia puber (13-18 tahun ) mulai terasa tidak di indahkan lagi.

Arah kebijakan pendidikan di Indonesia

1. Mengupayakan perluasan dan pemerataan kesempatan memperoleh pendidikan yang bermutu tinggi bagi seluruh rakyat Indonesia menuju terciptanya manusia Indonesia berkualitas tinggi dengan peningkatan anggaran pendidikan secara berarti.

2. Meningkatkan kemampuan akademik dan professional serta meningkatkan jaminan kesejahteraan tenaga pendidik mampu berfungsi secara optimal terutama dalam peningkatan pendidikan watak dan budi pekerti agar dapat mengembalikan wibawa lembaga dan tenaga kependidikan.

3. Melakukan pembaharuan sistem pendidikan termasuk pembaharuan kurikulum, berupa diversifikasi kurikulum untuk melayani keberagaman peserta didik, penyusunan kurikulum yang berlaku nasional dan lokal yang 
sesuai dengan kepentingan setempat, serta diversifikasi jenis pendidikan secara professional.

4. sebagai pusat pembudayaan nilai, sikap, dan kemampuan, serta meningkatkan partisipasi keluarga dan masyarakat yang didukung oleh sarana dan prasarana memadai.

5. Melakukan pembaharuan dan pemantapan sistem pendidikan nasional berdasarkan prinsip desentralisasi, otonomi keilmuan dan manajemen.

6. Meningkatkan kualitas lembaga pendidikan yang diselenggarakan baik oleh masyarakat maupun pemerintah untuk memantapkan sistem pendidikan yang efektif dan efisien dalam menghadapi perkembangan ilmu pengetahuan, teknologi dan seni.

7. Mengembangkan kualitas sumber daya manusia sedini mungkin secara terarah, terpadu dan menyeluruh melalui berbagai upaya proaktif dan reaktif oleh seluruh komponen bangsa agar generasi muda dapat berkembang secara optimal disertai dengan hak dukungan dan lindungan sesuai dengan potensinya.

8. Meningkatkan penguasaan, pengembangan dan pemanfaatan ilmu pengetahuan dan teknologi, termasuk teknologi bangsa sendiri dalam dunia usaha, terutama usaha kecil, menengah, koperasi.

Guna meningkatkan Kebijakan pendidikan memiliki karakteristik yang khusus, yakni:

1. Memiliki tujuan pendidikan.

Kebijakan pendidikan harus memiliki tujuan, namun lebih khusus, bahwa ia harus memiliki tujuan pendidikan yang jelas dan terarah untuk memberikan kontribusi pada pendidikan.

2. Memenuhi aspek legal-formal.

Kebijakan pendidikan tentunya akan diberlakukan, maka perlu adanya pemenuhan atas pra-syarat yang harus dipenuhi agar kebijakan pendidikan itu diakui dan secara sah berlaku untuk sebuah wilayah. Maka, kebijakan pendidikan harus memenuhi syarat konstitusional sesuai dengan hierarki konstitusi yang berlaku di sebuah wilayah hingga ia dapat dinyatakan sah dan resmi berlaku di wilayah tersebut. Sehingga, dapat dimunculkan suatu kebijakan pendidikan yang legitimat.

3. Memiliki konsep operasional 
Kebijakan pendidikan sebagai sebuah panduan yang bersifat umum, tentunya harus mempunyai manfaat operasional agar dapat diimplementasikan dan ini adalah sebuah keharusan untuk memperjelas pencapaian tujuan pendidikan yang ingin dicapai. Apalagi kebutuhan akan kebijakan pendidikan adalah fungsi pendukung pengambilan keputusan.

4. Dibuat oleh yang berwenang

Kebijakan pendidikan itu harus dibuat oleh para ahli di bidangnya yang memiliki kewenangan untuk itu, sehingga tak sampai menimbulkan kerusakan pada pendidikan dan lingkungan di luar pendidikan. Para administrator pendidikan, pengelola lembaga pendidikan dan para politisi yang berkaitan langsung dengan pendidikan adalah unsur minimal pembuat kebijakan pendidikan.

\section{Dapat dievaluasi}

Kebijakan pendidikan itu pun tentunya tak luput dari keadaan yang sesungguhnya untuk ditindak lanjuti. Jika baik, maka dipertahankan atau dikembangkan, sedangkan jika mengandung kesalahan, maka harus bisa diperbaiki. Sehingga, kebijakan pendidikan memiliki karakter dapat memungkinkan adanya evaluasi secara mudah dan efektif.

6. Memiliki sistematika

Kebijakan pendidikan tentunya merupakan sebuah sistem juga, oleh karenanya harus memiliki sistematika yang jelas menyangkut seluruh aspek yang ingin diatur olehnya. Sistematika itu pun dituntut memiliki efektifitas, efisiensi dan sustainabilitas yang tinggi agar kebijakan pendidikan itu tidak bersifat pragmatis, diskriminatif dan rapuh strukturnya akibat serangkaian faktor yang hilang atau saling berbenturan satu sama lainnya. Hal ini harus diperhatikan dengan cermat agar pemberlakuannya kelak tidak menimbulkan kecacatan hukum secara internal. Kemudian, secara eksternal pun kebijakan pendidikan harus bersepadu dengan kebijakan lainnya; kebijakan politik; kebijakan moneter; bahkan kebijakan pendidikan di atasnya atau disamping dan dibawahnya, serta daya saing produk yang berbasis sumber daya lokal.

Kebijakan otonomi pendidikan dalam konteks otonomi daerah sebagai berikut, diantaranya:

a) Secara general otonomi pendidikan menuju pada upaya meningkatkan mutu pendidikan sebagai jawaban atas "kekeliruan" kita selama lebih dari 20 tahun bergelut dengan persoalan-persoalan kuantitas. 
b) Pada sisi otonomi daerah, otonomi pendidikan mengarah pada menipisnya kewenangan pemerintah pusat dan membengkaknya kewenangan daerah otonom, atas bidang pemerintahan berlabel pendidikan yang harus disertai dengan tumbuhnya pemberdayaan dan partisipasi masyarakat.

c) Terdapat potensi tarik menarik antara otonomi pendidikan dalam konteks otonomi daerah dalam menempatkan kepentingan ekonomik dan finansial sebagai kekuatan tarik menarik antara pemerintahan daerah otonom dan institusi pendidikan.

d) Kejelasan tempat bagi institusi-institusi pendidikan perlu diformulasikan agar otonomi pendidikan dapat berjalan pada relnya.

e) Pada tingkat persekolahan, otonomi pendidikan berjalan atas dasar desentralisasi dan prinsip School Based Management pada tingkat pedidikan dasar dan menengah; penataan kelembagaan pada level dan tempat yang menjadi faktor kunci keberhasilan otonomi pendidikan.

f) Sudah selayaknya jika otonomi pendidikan harus bergandengan dengan kebijakan akuntabiliti terutama yang berkaitan dengan mekanisme pendanaan atau pembiayaan pendidikan.

g) Pada level pendidikan tinggi, kebijakan otonomi masih tetap berada dalam kerangka otonomi keilmuan.

h) Dalam konteks otonomi daerah, kebijakan otonomi pendidikan tinggi dapat ditempatkan bukan pada kepentingan daerah semata-semata melainkan pada kenyataan bahwa pendidikan tinggi adalah aset nasional.

i) Secara makro, apapun yang terkandung di dalamnya, otonomi pendidikan tinggi haruslah menonjolkan keunggulan-keunggulannya. (Yoyon, 2000:6). ${ }^{[4]}$

\section{B. Dasar Hukum Kebijakan Pemerintah dalam Pendidikan}

- Menurut Masnuh dalam (Amnur,2007) pendidikan merupakan suatu kegiatan, proses, hasil dan sebagai ilmu yang pada dasarnya merupakan sebagai usaha sadar yang dilakukan manusia sepanjang hayat guna memenuhi kebutuhan hidup. Pandangan ini secara umum telah menjadi istilah konvensional di masyarakat dan sarana manusia memperoleh pengetahuan secara berkesinambungan. Pada dasarnya, bahwa kebijakan pemerintah Indonesia 2009-2014 yang memiliki orientasi basis ekonomi sesuai dengan rancangan strategis pendidikan nasional 2009-2014 yang 
mengacu pada amanat Undang-Undang Dasar Tahun 1945, amandemen ke empat pasal 31 tentang pendidikan, Ketetapan MPR Nomor VII/ MPR/ 2001 tentang Visi Indonesia Masa Depan, Undang-undang Nomor 17 Tahun 2003 tentang Sistem Pendidikan Nasional (Sisdiknas), Undangundang Nomor 17 Tahun 2003 tentang keuangan negara, undang-undang nomor 25 tahun 2004 tentang sistem perencanaan pembangun nasional, uu nomor 32 tahun 2004 tentang pemerintah daerah, uu nomor 33 tahun 2004 tentang pemerintahan daerah, uu nomor 33 tahun 2004 tentang perimbangan keunganan antara pemerintah pusat dan pemerintah daerah, undang-undang nomor 14 tahun 2005 tentang guru dan dosen, PP Nomor 20 tahun 2004 tentang rencana kerja dan anggaran kementerian /lembaga, PP Nomor 19 tahun 2005 tentang standar nasional pendidikan dan PP Nomor 66 Tahun 2010 tentang pengelolaan dan penyelenggaraan pendidikan. ${ }^{[5]}$

\section{- KESIMPULAN}

Pendidikan merupakan salah satu faktor utama untuk dapat mencapai kemakmuran suatu Negara. Tetapi prombelmatika di dunia pendidikan nampaknya selalu jadi bahan bahasan yang tak akan pernah habis, mulai dari kondisi sekolah, peserta didik dan pendidik sendiri. Hal ini tentu mengundang berbagai kebijakan yang harus sesuai dengan harapan masyarakat. Pada dasarnya, bahwa kebijakan pemerintah Indonesia yang memiliki orientasi basis ekonomi sesuai dengan rancangan strategis pendidikan nasional yang mengacu pada amanat undang-undang dasar tahun 1945, dan suatu kebijakan pemerintah juga harus mempunyai arah yang jelas karena ini menyangkut tentang kecerdasan anak didiknya tersebut. 


\section{Latihan-latihan}

Pilihan Ganda (PG)

1. Pasal berapa yang mengatur tentang kemakmuran suatu negara?

a. 31 ayat $(1,2,3)$ Undang-Undang Dasar 1945

b. 33 ayat $(2,1,3)$ Undang-Undang Dasar 1945

c. 32 ayat $(1,2,3)$ Undang-Undang Dasar 1945

d. 31 ayat $(2,1,3)$ Undang-Undang Dasar 1945

2. Pengelolaan dan penyelenggaraan pendidikan diatur dalam PP nomor?

a. 66 tahun 2010

b. 66 tahun 2000

c. 66 tahun 2005

d. 66 tahun 2009

3. Ketetapan MPR Nomor VIII/MPR/2001 berisi tentang?

a. Misi Indonesia di masa depan

b. Tujuan Indonesia di masa depan

c. Visi Indonesia di masa depan

d. Semua jawaban benar

4. Apa kepanjangan dari BSNP?

a. Badan Standar Nasional Pemerintah

b. Badan Standar Nasional Pendidikan

c. Bagan Struktur Nasional Pelatihan

d. Badan Standar Nasional Peruundang-undangan

5. Menurut pesikolog bilamana seorang anak memiliki IQ 130 itu berada pada tingkat?
a. Excelent
b. Perfect
c. Sempurna
d. very superior 
6. Kebijakan pemerintah dalam dunia pendidikan yang sangat dibutuhkan adalah
a. Bantuan Oprasional Sekolah (BOS)
b. Beasiswa
c. SPP
d. SKS

7. Bagaimana cara melakukan pembaharuan dan pemantapan system pendidikan nasional?
a. Sistem komputerisasi
b. Program Beasiswa
c. Prinsip desentralisasi, otonomi keilmuan dan manajemen
d. PNS

8. Apa isi ayat 1 dari pasal 31 UUD 1945?

a. Seluruh warga Indonesia berhak berpendidikan

b. Setiap warga negara berhak mendapat pendidikan

c. Pemerintah beri fasilitas pendidikan ke setiap daerah

d. Warga Indonesia berhak mendapat pendidikan

9. BOS lebih utamakan pada orang yang?

a. Membutuhkan

b. Fasilitas sekolah

c. Sertifikasi guru

d. Siswa tak mampu, peembangunan fisik gedung sekolah, tunjangan sertifikasi bagi para guru.

10. Undang-undang yang mengatur tenttang system oendidikan nasional pada saat ini adalah ...
a. UU No . 21 Tahun 2003
b. UU No . 23 Tahun 2009
c. UU No . 20 Tahun 2000
d. UU No . 20 Tahun 2003

Essai : 
1. Apa yang dimaksud dengan kebijakan pendidikan?

2. Bagaimana bunyi pasal 31 ayat (1) (2) (3) tentang pendidikan?

3. Bagaimana Definisi pendidikan Menurut Masnuh dalam (Amnur,2007)?

4. Sebutkan macam-macam karakteristik dalam kebijakan pendidikan

5. Jelaskan Kebijakan otonomi pendidikan dalam konteks otonomi daerah !

6. Petunjuk kerja, dapat berupa Lembar Kerja (L.K)

Untuk mengerjakan tugas di atas langkah-langkah yang harus ditempuh adalah sebagai berikut:

1) Membentuk kelompok 3-5 orang perkelompok

2) Mendiskusikan dalalm kelompok tentang masalah diatas

3) Menyusun laporan diskusi

4) Melaporkan dalam bentuk lembar hasil diskusi kepada doosen Pembina

7. Evaluasi

Lakukan analisis untuk pertanyaan brikut :

Apakah produk perundangan lahir dari kebijakan atau kebijakan yang lahir karena ada peraturan perundangan

Jawab : Kebijakan lah yang lahir setelah adanya peraturan perundangan karena adanya peraturan perundang-undangan itu untuk mengatur dan memperkuat adanya kebijakan-kebijakan yang sudah dibuat oleh pemerintah, jika seorang pelaku menyalah gunakan atau melanggar kebijakan yang ada maka bisa dikenakan pasal yang sudah tercantum sesuai dalam undang-undang yang telah tertera sebelumnya. Bahwa kebijakan dibuat untuk pedoman dalam bertindak dan mengarahkan untuk tidak menyalah gunakannya.

8. Respon atau balikan terhadap hasil evaluasi

Penilaian yang dilakukan meliputi :

1. Ada makalah hasil analisis (bobot nilai 5)

2. Ada analisis atas persoalan diatas yang memenuhi kriteria; kajian teori, contoh kasus, dan strategi analisisnya(bobot nilai 70)

3. Kondisi makalah; baik, bersih, bahasa penulisan(25)

Keterangan

Tingkat penguasaan $=$ $\mathrm{x} 100 \%$

100

Arti tingkat penguasaan anda : 


$$
\begin{aligned}
& 90 \%-100 \%=\mathrm{A} \\
& 80 \%-89 \%=\mathrm{B} \\
& 70 \%-79 \%=\mathrm{C} \\
& <70 \%=\mathrm{D}
\end{aligned}
$$

Jawaban Pilihan Ganda (PG) :

1. A 6

2. A 7. C

3. $\mathrm{C} \quad 8 . \mathrm{B}$

4. B 9. D

5. D 10. D

Jawaban Essai :

1. Kebijakan pendidikan merupakan suatu sikap dan tindakan yang di ambil seseorang atau dengan kesepakatan kelompok pembuat kebijakan sebagai upaya untuk mengatasi masalah atau suatu persoalan dalam dunia pendidikan.

2. Pasal 31 ayat (1) Undang Undang Dasar 1945 (UUD 1945) yang menyatakan bahwa setiap warga Negara berhak mendapat pendidikan. Ayat (2) menegaskan bahwa setiap warga Negara wajib mengikuti pendidikan dasar dan pemerintah wajib membiayainya. Ayat (3) menetapkan bahwa pemerintah mengusahakan dan menyelenggarakan suatu sistem pendidikan nasional, yang meningkatkan keimanan dan ketaqwaan serta akhlak mulia dalam rangka mencerdaskan kehidupan bangsa, yang diatur dengan undang-undang.

3. Pendidikan merupakan suatu kegiatan, proses, hasil dan sebagai ilmu yang pada dasarnya merupakan sebagai usaha sadar yang dilakukan manusia sepanjang hayat guna memenuhi kebutuhan hidup.

4. Jawaban :

- Memiliki tujuan pendidikan.

- Memenuhi aspek legal-formal

- Memiliki aspek oprasional

- Dibuat oleh yang berwenang

- Dapat dievaluasi

- Memiliki sistematika

5. Jawaban : 
- Secara general otonomi pendidikan menuju pada upaya meningkatkan mutu pendidikan sebagai jawaban atas "kekeliruan" kita selama lebih dari 20 tahun bergelut dengan persoalan-persoalan kuantitas.

- Pada sisi otonomi daerah, otonomi pendidikan mengarah pada menipisnya kewenangan pemerintah pusat dan membengkaknya kewenangan daerah otonom, atas bidang pemerintahan berlabel pendidikan yang harus disertai dengan tumbuhnya pemberdayaan dan partisipasi masyarakat.

- Terdapat potensi tarik menarik antara otonomi pendidikan dalam konteks otonomi daerah dalam menempatkan kepentingan ekonomik dan finansial sebagai kekuatan tarik menarik antara pemerintahan daerah otonom dan institusi pendidikan.

- Kejelasan tempat bagi institusi-institusi pendidikan perlu diformulasikan agar otonomi pendidikan dapat berjalan pada relnya.

- Pada tingkat persekolahan, otonomi pendidikan berjalan atas dasar desentralisasi dan prinsip School Based Management pada tingkat pedidikan dasar dan menengah; penataan kelembagaan pada level dan tempat yang menjadi faktor kunci keberhasilan otonomi pendidikan.

- Sudah selayaknya jika otonomi pendidikan harus bergandengan dengan kebijakan akuntabiliti terutama yang berkaitan dengan mekanisme pendanaan atau pembiayaan pendidikan.

- Pada level pendidikan tinggi, kebijakan otonomi masih tetap berada dalam kerangka otonomi keilmuan.

- Dalam konteks otonomi daerah, kebijakan otonomi pendidikan tinggi dapat ditempatkan bukan pada kepentingan daerah sematasemata melainkan pada kenyataan bahwa pendidikan tinggi adalah aset nasional.

- Secara makro, apapun yang terkandung di dalamnya, otonomi pendidikan tinggi haruslah menonjolkan keunggulankeunggulannya. (Yoyon, 2000:6) 


\section{BAB VIII \\ PENGELOLAAN PENDIDIKAN}

\section{1) Pokok Bahasan}

Pengelolaan pendidikan

\section{2) Kompeten Yang Akan Tercapai}

Pemahaman tentang pengelolaan pendidikan ditinjau dari permendiknas no 19 tahun 2007

\section{3) Petunjuk Belajar (Petunjuk Yang Diperuntukkan Bagi Mahasiswa)}

- Membentuk kelompok 5-7 orang

- Membuat makalah

- Melakukan presentasi dikelas

\section{4) Content Atau Isi Materi}

\section{A. Pengelolaan Pendidikan}

Pengelolaan pendidikan berasal dari kata manajemen, sedangkan istilah manajemen sama artinya dengan administrasi (Oteng Sutisna:1983). Dapat diartikan pengelolaan pendidikan sebagai upaya untuk menerapkan kaidah-kaidah adiministrasi dalam bidang pendidikan. Pengelolaan pendidikan meliputi kegiatan perencanaan, pengorganisasian, pengarahan, pengawasan dan pengembangan. Pengelolaan adalah suatu proses perencanaan, pengorganisasian, kepemimpinan dan pengendalian upaya anggota organisasi dimana keempat proses tersebut mempunyai fungsi masing-masing untuk mencapai suatu tujuan organisasi. Menurut Griffin pengelolaan adalah sebagai sebuah proses perencanaan, pengorganisasian, pengkoordinasian dan pengontrolan sumber daya untuk mencapai sasaran secara efektif dan efisien.

\section{B. Landasan Hukum Pengelolaan Pendidikan}

Pengelolaan pendidikan mengacu pada undang-undang dan peraturan pemerintah sebagai berikut:

1. Undang-undang no.2 tahun 1989 tentang sistem Pendidikan Nasional. 
2. Peraturan pemerintah no.28 tahun 1990 tentang Pendidikan Dasar.

3. Keputusan mentri pendidikan dan kebudayaan no. 060/V/1993 tentang Kurikulum Pendidikan Dasar.

4. Keputusan Kepala kantor wilayah Departemen Pendidikan dan Kebudayaan Propinsi Jawa Barat no. 979/102/kep/I/1994 tentang kurikulum Muatan Lokal Pendidikian Dasar Propinsi Jawa Barat. ${ }^{(1)}$

5. Keputusan Kepala Dinas Kota Cimahi no. 800/1330-Disdik/2009 tentang Pedoman Penyusunan Rencana Pendapatan dan Belanja Sekolah

\section{Tujuan Pengelolaan Pendidikan}

Pengelolaan pendidikan ini meliputi beberapa tujuan yaitu:

1. Untuk meningkatkan dan memaksimalkan segenap sumberdaya pendidikan SMP sehingga mampu mencapai tujuan pendidikan.

2. Sebagai acuan pelaksanaan penyelenggaraan pendidikan di sekolah, sekaligus sebagai alat evaluasi penyelenggaraan kegiatan baik selama pengelolaan berlangsung maupun akhir tahun pelajaran.(1)

\section{Permendiknas Nomor 19 Tahun 2007}

Pasal 1 (1) Setiap satuan pendidikan wajib memenuhi standar pengelolaan pendidikan yang berlaku secara nasional. (2) Standar pengelolaan pendidikan sebagaimana dimaksud pada ayat (1) tercantum dalam Lampiran Peraturan Menteri ini. Pasal 2 Peraturan Menteri ini mulai berlaku pada tanggal ditetapkan. Ditetapkan Jakarta 23 Mei 2007 Permendiksnas No.19 Tahun 2007 ini merupakan penejelasan dari PP No.19 Tahun 2005 mengenai standar pengelolaan. Permen ini membahas standardisasi ,penegelolaan pendidikan yang diselenggarakan oleh satuan pendidikan dasar dan menengah. Selain itu, Permendiknas ini merupakan penjabaran lebih rinci dari UU sistem pendidikan nasioanal. Secara garis besar, peraturan ini hanya memuat dua pasal. Selebihnya, penejelasan dari permen ini ada pada bagaian lampiran. Dalam lampiran permendiknas ini ada enam poin penting yang arus diperhatikan oleh setiap satuan pendidikan dasar dan menengah. Enam poin tersebut adalah

1. Perencanaan Program

2. Pelaksanaan Rencana Kerja

3. Pengawasan dan Evaluasi

4. Kepemimpinan Sekolah/Madrasah ${ }^{(1)}$

5. Sistem Informasi Manajemen 
6. Penilaiaan Khusus Dalam Permendiknas ini terkandung beberapa poinpenting, diantaranya :

\section{Perencanaan Program}

Perencanaan program dalam pengelolaan pendidikan meliputi

Pembuatan Visi, Misi, Tujuan, dan rencana Kerja.

\section{a. Visi sekolah/madrasah:}

Visi merupakan gambaran tentang masa depan (future) yang realistik dan ingin diwujudkan dalam kurun waktu tertentu.

Visi adalah pernyataan yang diucapkan atau ditulis hari ini, yang merupakan proses manajemen saat ini yang menjangkau masa yang akan datang (Akdon, 2006:94). Hax dan Majluf dalam Akdon (2006:95) menyatakan bahwa visi adalah pernyataan yang merupakan sarana untuk: Bagi sekolah .Visi adalah imajinasi moral yang menggambarkan profil sekolah yang diinginkan di masa datang. Imajinasi ke depan seperti itu akan selalu diwarnai oleh peluang dan tantangan yang diyakini akan terjadi di masa datang. Dalam menentukan visi tersebut, sekolah harus memperhatikan perkembangan dan tantangan masa depan.

Visi sekolah menurut Permendiknas No 19 Tahun 2007 arus memenuhi kritria sebagai berikut:

1. dijadikan sebagai cita-cita bersama warga sekolah/madrasah dan segenap pihak yang berkepentingan pada masa yang akan datang;

2. mampu memberikan inspirasi, motivasi, dan kekuatan pada warga sekolah/madrasah dan segenap pihak yang berkepentingan;

3. dirumuskan berdasar masukan dari berbagai warga sekolah/madrasah dan pihak-pihak yang berkepentingan, selaras dengan visi institusi di atasnya serta visi pendidikan nasional;

4. diputuskan oleh rapat dewan pendidik yang dipimpin oleh kepala sekolah/madrasah dengan memperhatikan masukan komite sekolah/madrasah;

5. disosialisasikan kepada warga sekolah/madrasah dan segenap pihak yang berkepentingan;

6. ditinjau dan dirumuskan kembali secara berkala sesuai dengan perkembangan dan tantangan di masyarakat ${ }^{(2)}$ 


\section{b. Misi Sekolah /Madrasah}

Misi adalah pernyataan mengenai hal-hal yang harus dicapai organisasi bagi pihak-pihak yang berkepentingan di masa datang (Akdon, 2006: 97). Pernyataan misi mencerminkan tentang penjelasan produk atau pelayanan yang ditawarkan. Misi merupakan tindakan atau upaya untuk mewujudkan visi. Jadi misi merupakan penjabaran visi dalam bentuk rumusan tugas, kewajiban, dan rancangan tindakan yang dijadikan arahan untuk mewujudkan visi. Dengan kata lain, misi adalah bentuk layanan untuk memenuhi tuntutan yang dituangkan dalam visi dengan berbagai indikatornya.

Misi sekolah menurut Permendiknas No.19 tahun 2007 harus memenuhi kriteria:

1. memberikan arah dalam mewujudkan visi sekolah/madrasah sesuai dengan tujuan pendidikan nasional;

2. merupakan tujuan yang akan dicapai dalam kurun waktu tertentu;

3. menjadi dasar program pokok sekolah/madrasah;

4. menekankan pada kualitas layanan peserta didik dan mutu lulusan yang diharapkan oleh sekolah/madrasah;

5. memuat pernyataan umum dan khusus yang berkaitan dengan program sekolah/madrasah;

6. memberikan keluwesan dan ruang gerak pengembangan kegiatan satuansatuan unit sekolah/madrasah yang terlibat;

7. dirumuskan berdasarkan masukan dari segenap pihak yang berkepentingan termasuk komite sekolah/madrasah dan diputuskan oleh rapat dewan pendidik yang dipimpin oleh kepala sekolah/madrasah

8. disosialisasikan kepada warga sekolah/madrasah dan segenap pihak yang berkepentingan;

9. ditinjau dan dirumuskan kembali secara berkala sesuai dengan perkembangan dan tantangan di masyarakat

\section{c.Tujuan Sekolah /Madrasah}

Tujuan menggambarkan arahan yang jelas bagi sekolah. Perumusan tujuan akan strategi/perlakuan, arah kebijakan dan program suatu sekolah. Oleh karena itu perumusan tujuan harus memberikan ukuran lebih spesifik dan akuntabel. . ${ }^{(2)}$ Perumusan tujuan menurut Permendiknas no.19 Tahun 2007 harus memenuhi kriteria sebagai berikut : 
1) menggambarkan tingkat kualitas yang perlu dicapai dalam jangka menengah (empat tahunan);

2) mengacu pada visi, misi, dan tujuan pendidikan nasional serta relevan dengan kebutuhan masyarakat;

3) mengacu pada standar kompetensi lulusan yang sudah ditetapkan oleh sekolah/madrasah dan Pemerintah;

4) mengakomodasi masukan dari berbagai pihak yang berkepentingan termasuk komite sekolah/madrasah dan diputuskan oleh rapat dewan pendidik yang dipimpin oleh kepala sekolah/madrasah;

5) disosialisasikan kepada warga sekolah/madrasah dan segenap pihak yang berkepentingan.

\section{d. Program/ Rencana Kerja Sekolah / Madrasah}

Program merupakan implementasi dari visi, misi dan tujuan. Program yang dimaksudkan dalam makalah ini adalah program operasional. Program operasional didefinisikan sebagai kumpulan kegiatan yang dihimpun dalam satu kelompok yang sama secara sendiri-sndiri atau bersama-sama untuk mencapai tujuan dan sasaran (Kdon, 2006:135). Program merupakan kumpulan kegiatan nyata, sistematis dan terpadu, dilaksanakan oleh satu instansi pemerintah atau lebih ataupun dalam rangka kerja sama dengan masyarakat atau yang merupakan partisipasi aktif masyarakat guna mencapai tujuan dan sasaran yang telah ditetapkan.Perumusan program kerja sekolah berdasarkan atas perumusan visi, misi, tujuan, sasaran, strategi dan kebijakan yang telah ditetapkan. Dalam merumuskan program kerja sekolah, ada beberapa hal yang perlu diperhatikan

a) Sekolah/Madrasah membuat:

- rencana kerja jangka menengah yang menggambarkan tujuan yang akan dicapai dalam kurun waktu empat tahun yang berkaitan dengan mutu lulusan yang ingin dicapai dan perbaikan komponen yang mendukung peningkatan mutu lulusan;

- rencana kerja tahunan yang dinyatakan dalam Rencana Kegiatan dan Anggaran Sekolah/Madrasah (RKA-S/M) dilaksanakan berdasarkan rencana jangka menengah

b) Rencana kerja jangka menengah dan tahunan sekolah/madrasah:

- disetujui rapat dewan pendidik setelah memperhatikan pertimbangan dari komite sekolah/madrasah dan disahkan berlakunya oleh dinas pendidikan 
kabupaten/kota. Pada sekolah/madrasah swasta rencana kerja ini disahkan berlakunya oleh penyelenggara sekolah/madrasah;

- dituangkan dalam dokumen yang mudah dibaca oleh pihak-pihak yang terkait.

c) Rencana kerja empat tahun dan tahunan disesuaikan dengan persetujuan rapat dewan pendidik dan pertimbangan komite sekolah/madrasah.

d) Rencana kerja tahunan dijadikan dasar pengelolaan sekolah/madrasah yang ditunjukkan dengan kemandirian, kemitraan, partisipasi, keterbukaan, dan akuntabilitas.

e) Rencana kerja tahunan memuat ketentuan yang jelas mengenai:

- kesiswaan;

- kurikulum dan kegiatan pembelajaran;

- pendidik dan tenaga kependidikan serta pengembangannya;

- $\quad$ sarana dan prasarana;

- keuangan dan pembiayaan;

- budaya dan lingkungan sekolah;

- peranserta masyarakat dan kemitraan; ${ }^{(3)}$

- rencana-rencana kerja lain yang mengarah kepada peningkatan dan pengembangan mutu.

\section{e. Pelaksanan Program}

Pelaksanaan Rencana Kerja Sekolah/Madrasah meliputi seluruh bidang pelaksanaan operasional sekolah, meliputi: bidang kesiswaan, kurikulum dan kegiatan pembelajaran, pendidik dan tenaga kependidikan, sarana dan prasarana, keuangan dan pembiayaan, budaya dan lingkungan sekitar serta peran serta masyarakat dan kemitraan sekolah. Seluruh bidang tersebut diselenggarakan dan dikelola oleh satuan pendidikan yang dibentuk dalam struktur organisasi sekolah/madrasah. Struktur organisasi sekolah terdiri dari: semua pimpinan, pendidik, dan tenaga kependidikan yang mempunyai uraian tugas, wewenang, dan tanggung jawab yang jelas tentang keseluruhan penyelenggaraan dan administrasi sekolah.(3)

Pelaksanaan rencana kerja/kegiatan sekolah dilaksanakan berdasarkan rencna kerja tahunan oleh penanggung jawab kegiatan. Berikut ini beberapa pelaksanaan kegiatan sekolah yang dilaksanakan berdasarkan bidang garapannya, meliputi: 


\section{Bidang Kesiswaan}

a. Menetapkan petunjuk pelaksanaan operasional mengenai proses penerimaan peserta didik.

b. Memberikan layanan konseling kepada peserta didik.

c. Melaksanakan kegiatan ekstra dan nonkurikuler untuk para peserta didik.

d. Melakukan pembinaan prestasi unggulan.

e. Melakukan pelacakan terhadap alumni.

\section{Bidang Kurikulum dan Kegiatan Pembelajaran}

a. Menyusun KTSP dan jadwal berdasarkan kalender pendidikan.

b. Menyusun dan mengembangkan program pembelajaran berdasarkan standar kompetensi dan kompetensi dasar yang ditetapkan.

c. Menyusun program penilaian hasil belajar peserta didik.

d. Menyusun dan menetapkan peraturan akademik.

\section{Bidang Pendidik dan Tenaga Kependidikan}

1) Menyusun program pendayagunaan pendidik dan tenaga kependidikan.

2) Mengangkat pendidik dan tenaga kependidikan tambahan yang dilaksanakan berdasarkan ketentuan yang telah ditetapkan oleh penyelenggara sekolah.

\section{Bidang Sarana dan Prasarana}

1) Menetapkan kebijakan program secara terttulis mengenai pengelolaan sarana dan prasarana.

2) Merencanakan, mengadakan, memelihara sarana dan prasarana yang ada di sekolah.

3) Menyusun skala prioritas pengembangan fasilitas pendidikan sesuai dengan tujuan pendidikan dan kurikulum.(3)

\section{Bidang Keuangan dan Pembiayaan}

Menyusun pedoman pengelolaan biaya investasi dan operasional yang mengacu pada standar pembiayaan.

\section{Bidang Budaya dan Lingkungan Sekolah}

a. Menciptakan suasana, iklim, dan lingkungan pendidikan yang kondusif untuk pembelajaran yang efisien dalam prosedur pelaksanaan.

b. Menetapkan pedoman tata tertib/peraturan sekolah.

c. Menetapkan kode etik warga sekolah.

\section{Bidang Humas/Peran serta Masyarakat dan Kemitraan Sekolah}


Sekolah menjalin kemitraan dan kerja sama dengan masyarakatt dan lembaga lain untuk mendukung program pelaksanaan kegiatan sekolah dalam rangka pengelolaan pendidikan.

\section{Pengawasan dan Evaluasi}

Pengawasan dapat diartikan sebagai proses kegiatan monitoring untuk meyakinkan bahwa semua kegiatan organisasi terlaksana seperti yang direncanakan dan sekaligus juga merupakan kegiatan untuk mengoreksi dan memperbaiki bila ditemukan adanya penyimpangan yang akan mengganggu pencapaian tujuan (Robbins 1997).

Sekolah harus objektif, bertanggung jawab dan berkelanjutan dalam melakukan pengawasan. Pengawasan meliputi pemantauan, supervise, evaluasi, pelaporan dan tindak lanjut hasil pengawasan. Pemantauan dilakukan oleh komite sekolah, sedangkan supervise dilakukan secara teratur dilakukan oleh kepala sekolah . guru melaporkan hasil evaluasi dan penilaian sekurang-kurangnya kepada kepala sekolah.

Setiap pihak yang menerima laporan hasil pengawasan harus menindaklanjuti setiap laporan yang diterimanya dan menggunakan hasil pemantauan atau pengawasan tersebut untuk memperbaiki kinerja sekolah dan sebagai sarana pendidikan.

\section{A. Program Evaluasi}

Jenis-Jenis Evaluasi:

1.Evaluasi diri adalah evaluasi yang dilakukan pihak sekolah untuk menilai kinerja sekolah itu sendiri. Pihak sekolah menetapkan prioritas indicator untuk mengukur, menilai kinerja dan melakukan perbaikan dalam rangka pelaksaaan Standar Nasional Pendidikan. Evaluasi diri atau evaluasi sekolah dilakukan secara periodic berdasarkan pada data dan informasi yang sahih ${ }^{(3)}$

2. Evaluasi dan pengembangan KTSP adalah proses yang dilakukan secara komprehensif dan flexible agar bisa menghadapi kemajuan ilmu pengetahuan dan teknologi yang mutakhir dan bersifat menyeluruh yang artinya melibatkan semua pihak

3. Evaluasi pendayagunaan pendidik dan tenaga pendidik meliputi kesesuaian penugasan dengan keahlian, keseimbangan beban kerja dan kinerja pendidik dan tenaga kependidikan dalam pelaksaan tugas. Evaluasi harus emperhatikan pencapaian prestasi dan perubahan perubahan peserta didik. 
Akreditasi sekolah merupakan suatu kegiatan yang dilakukan oleh pemerintah atau lembaga yang berwenang untuk menentukan tingkat kelayakan suatu sekolah/madrasah berdasarkan kriteria yang telah ditetapkan, sebagai bentuk akuntabilitas publik yang dilakukan secara obyektif, adil, transparan, dan komprehensif dengan menggunakan instrumen dan kriteria yang mengacu kepada Standar Nasional Pendidikan.

4. Kepemimpinan Sekolah

Secara umum kepemiminan dapat dirumuskan sebagai berikut. "Kepemimpinan berarti kemauan dan kesiapan yang dimiliki oleh seseorang untuk dapat memengaruhi, mendorong, mengajak, menuntun, menggerakan, mengarahkan dan kalau perlu memaksa orang atau kelompok agar menerima pengaruh tersebut dan selanjutnya berbuat sesuatu yang dapat menbantu tercapainya suatu tujuan tertentu ang telah ditetapkan.

Kepemimpinan adalah proses mempengaruhi kegiatan-kegiatan kelompok yang diorganisir menuju kepada penentuan dan pencapaian tujuan (Ralp M Stogdil). Sedangkan menurut Sondang P. Siagian, kepemimpinan mrupakan motor atau daya penggerak daripada semua sumber-sumber, dan alat yang tersedia bagi suatu organisasi. ${ }^{(3)}$

\section{B. Fungsi Pemimpin}

Fungsi utama pemmpin pendidikan adalah kelompok untuk belajar memutuskan dan bekerja, antara lain:

1) Pemimpin membantu terciptanya suasana persaudaraan, kerjasama dengan penuh rasa kebebasan.

2) Pemimpin membatu kelompok untuk menorganisir diri yaitu ikut serta dalam memberikan rangsangan dan bantuan kepada kelompok dalam menetapkan dan menjelaskan tujuan. ${ }^{(3)}$

3) Pemimpin membantu kelompok dalam menetapkan prosedur kerja, yaitu membantu kelompok dalam menganalisis situasi untuk kemudian mentapkan prosedur mana yang paling praktis dan efektif. ${ }^{(3)}$

4) Pemimpin bertanggung jawb dalam mengambil keputusan bersama dengan kelompok. Pemimpin member kesempatan kepada kelompok untuk belajar dari pengalaman. Pemimpin mempunyai tanggung jawab untuk melatih kelompok menyadari proses dan isi pekerjaan yang dilakukan dan beran menilai hasilnya secara jujur dan objektif. 


\section{Tugas dan Kewajiban Pemimpin sekolah/madrasah :}

1. Menjabarkan visi ke dalam misi target mutu yang akan dicapai

2. Merumuskan tujuan dan target mutu yang akan dicapai

3. Menganalisis tnatangan, peluang, kekuatan dan kelemahan sekolah dan madrasah

4. Membuat rencana kerja strategis dan rencan kerja tahunan untuk pelaksanaan peningkatan mutu

5. Bertanggung jawab dalam membuat keputusan anggaran sekolah dan madrasah

6. Melibatkan guru, komite sekolah dalam pengambilan keputusan penting sekolah/madrasah. Dalam hal ini sekolah / madrasah swasta, pengambilan keputusan tersebut harus melibatkan penyelenggara sekolah dan madrasah.

7. Berkomunikasi untuk menciptakan dukungan intensif dari orang tua peserta didikdan masyarakat

8. Menjaga dan meningkatkan motivasi kerja pendidikan dan tenaga kependidikan dengan menggunakan sistem pemberian penghargaan atas prestasi dan sangsi atas pelanggaran peraturan dank kode etik

9. Menciptakan lingkungan pembelajaran yang efektif bagi peserta didik

10. Bertanggungjawab atas perencanaan partisifatif mengenai pelaksanaan dan kurikulum

11. Melaksanakan dan merumuskan program supervise, serta memanfaatkan hasil supervise untuk meningkatkan kinerja sekolah dan madrasah

12. Meningkatkan mutu pendidikan ${ }^{(3)}$

13. Member teladan dan menjaga nama baik lembaga, profesi dan kedudukan sesuaidengan kepercayaan yang diberikan kepadanya

14. Memfasilitasi pengembanga, penyebarluasan dan pelaksanaan visi pembelajaran yang dikomunikasikan dengan baik dan didukung oleh komunitas sekolah/madrasah ${ }^{(3)}$

15. Membantu, membina dan mempertahankan lingkungan sekolah / madrasah dan progam pembelajaran yang kondusif bagi proses belajar peserta didik dan pertumbuhan profesional para guru dan tenaga kependidikan

16. Menjamin manajemen organisasi dan pengoperasian sumber daya sekolah/madrasah untuk menciptakan lingkungan belajar yang aman, sehat efisien dan efektif 
17. Menjalin kerjasama dengan orang tua peserta didik dan masyarakat dan komite sekolah /madrasah menanggapi kepentingan dan kebutuhan komunitas yang beragam dan memobilisasi sumber daya masyrakat

18. Member contoh/teladan/tindakan yang bertanggung jawab ${ }^{(3)}$

\section{Kesimpulan}

pengelolaan pendidikan sebagai upaya untuk menerapkan kaidah-kaidah adiministrasi dalam bidang pendidikan. Pengelolaan pendidikan meliputi kegiatan perencanaan, pengorganisasian, pengarahan, pengawasan dan pengembangan. Pengelolaan adalah suatu proses perencanaan, pengorganisasian, kepemimpinan dan pengendalian upaya anggota organisasi dimana keempat proses tersebut mempunyai fungsi masing-masing untuk mencapai suatu tujuan organisasi.

\section{Evaluasi}

Pilihlah jawaban yang bener untuk setiap dibawah ini dengan membubuhkan tanda silang ( $\mathrm{x}$ ) pada alternatif-alternatif jawaban yang ada.

1. Ada berapa Perencanaan Program .
a. 5 program
b. 6 program
c. 4 program
d. 3 program
e. 7 program

2. Perumusan tujuan menurut Permendiknas no.19 Tahun 2007 harus memenuhi kriteria sebagai berikut ini .
a. menggambarkan tingkat kualitas yang perlu dicapai dalam jangka menengah (empat tahunan).
b. mengacu pada visi, misi, dan tujuan pendidikan nasional serta relevan dengan kebutuhan masyarakat.
c. mengacu pada standar kompetensi lulusan yang sudah ditetapkan oleh sekolah/madrasah dan Pemerintah.
d. semua jawaban diatas salah.
e. semua jawaban benar. 
3. Fungsi utama pemmpin pendidikan adalah kelompok untuk belajar memutuskan dan bekerj kecuali .

a. Pemimpin membantu terciptanya suasana persaudaraan, kerjasama dengan penuh rasa kebebasan

b. Pemimpin membatu kelompok untuk menorganisir diri yaitu ikut serta dalam memberikan rangsangan dan bantuan kepada kelompok dalam menetapkan dan menjelaskan tujuan.

c. Pemimpin membantu kelompok dalam menetapkan prosedur kerja, yaitu membantu kelompok dalam menganalisis situasi untuk kemudian mentapkan prosedur mana yang paling praktis dan efektif.

d. Menjabarkan visi ke dalam misi target mutu yang akan dicapai.

e. Semua jawaban benar.

4. Ada berapa poin Tugas dan Kewajiban Pemimpin sekolah/madrasah.
a. 11 poin
b. 12 poin
c. 15 poin
d. 18 poin
e. 13 poi

5. Menyusun program pendayagunaan pendidik dan tenaga kependidikan temasuk dalam bidang.
a. Bidang kebudayaan
b. Bidang tenaga
c. Bidang kependidikan
d. Bidang keilmuan
e. Bidang pendidik dan bidang kependidikan

6. Menetapkan pedoman tata tertib/peraturan sekolah
a. Bidang budaya
b. Bidang lingkungan
c. Bidang budaya dan lingkungan sekolah
d. Bidang keilmuan
e. Bidang pendidik

7. Menyusun pedoman pengelolaan biaya investasi dan operasional yang mengacu pada standar pembiayaan. 

a. Bidang keuangan
b. Bidang pembiyayan
c. Bidang kebudayaan
d. Bidang administrasi
e. Bidang keuangan dan pembiyayaan

8. Rencana kerja tahunan dijadikan dasar pengelolaan sekolah/madrasah yang ditunjukkan dengan.
a. kemandirian,
b. kemitraan
c. partisipasi
d. keterbukaan, dan akuntabilitas
e. Semua jawaban benar

9. Memberikan layanan konseling kepada peserta didik. termasuk kedalam bidang.
a. Bidang keuangan
b. Bidang kebudayaan
c. Bidang keuangan dan pembiyayan
d. Bidang lingkungan
e. Bidang kesiswaan

10. Pengawasan meliput kecuali
a) pemantauan
b) supervise
c) evaluasi, pelaporan
d) tindak lanjut hasil pengawasan
e) penglihatan

\section{Latihan-latihan}

1. Sebutkan beberapa pelaksanaan kegiatan sekolah yang dilaksanakan berdasarkan bidang garapannya, meliputi.

2. Dalam lampiran permendiknas ini ada enam poin penting yang arus diperhatikan sebutkan enam pon tersebut.

3. Sebutkan beberapa Misi sekolah menurut Permendiknas No.19 tahun 2007 harus memenuhi kriteria.

4. Perencanaan program dalam pengelolaan pendidikan meliputi . 
5. Keputusan Kepala Dinas Kota Cimahi no. 800/1330-Disdik/2009 tentang Pedoman.

\section{BAB IX \\ PENGELOLAAN PENDIDIKAN}

\section{1) Pokok Bahasan}

Pengelolaan pendidikan

\section{2) Kompeten Yang Akan Tercapai}

Pemahaman tentang pengelolaan pendidikan ditinjau dari permendiknas no 19 tahun 2007

\section{3) Petunjuk Belajar (Petunjuk Yang Diperuntukkan Bagi Mahasiswa)}

- Membentuk kelompok 5-7 orang

- Membuat makalah

- Melakukan presentasi dikelas

\section{4) Content Atau Isi Materi}

\section{A. Pengelolaan Pendidikan}

Pengelolaan pendidikan berasal dari kata manajemen, sedangkan istilah manajemen sama artinya dengan administrasi (Oteng Sutisna:1983). Dapat diartikan pengelolaan pendidikan sebagai upaya untuk menerapkan kaidah-kaidah adiministrasi dalam bidang pendidikan. Pengelolaan pendidikan meliputi kegiatan perencanaan, pengorganisasian, pengarahan, pengawasan dan pengembangan. Pengelolaan adalah suatu proses perencanaan, pengorganisasian, kepemimpinan dan pengendalian upaya anggota organisasi dimana keempat proses tersebut mempunyai fungsi masing-masing untuk mencapai suatu tujuan organisasi. Menurut Griffin pengelolaan adalah sebagai sebuah proses perencanaan, pengorganisasian, pengkoordinasian dan pengontrolan sumber daya untuk mencapai sasaran secara efektif dan efisien.

\section{B. Landasan Hukum Pengelolaan Pendidikan}

Pengelolaan pendidikan mengacu pada undang-undang dan peraturan pemerintah sebagai berikut:

6. Undang-undang no.2 tahun 1989 tentang sistem Pendidikan Nasional. 
7. Peraturan pemerintah no.28 tahun 1990 tentang Pendidikan Dasar.

8. Keputusan mentri pendidikan dan kebudayaan no. 060/V/1993 tentang Kurikulum Pendidikan Dasar.

9. Keputusan Kepala kantor wilayah Departemen Pendidikan dan Kebudayaan Propinsi Jawa Barat no. 979/102/kep/I/1994 tentang kurikulum Muatan Lokal Pendidikian Dasar Propinsi Jawa Barat. ${ }^{(1)}$

10. Keputusan Kepala Dinas Kota Cimahi no. 800/1330-Disdik/2009 tentang Pedoman Penyusunan Rencana Pendapatan dan Belanja Sekolah

\section{Tujuan Pengelolaan Pendidikan}

Pengelolaan pendidikan ini meliputi beberapa tujuan yaitu:

3. Untuk meningkatkan dan memaksimalkan segenap sumberdaya pendidikan SMP sehingga mampu mencapai tujuan pendidikan.

4. Sebagai acuan pelaksanaan penyelenggaraan pendidikan di sekolah, sekaligus sebagai alat evaluasi penyelenggaraan kegiatan baik selama pengelolaan berlangsung maupun akhir tahun pelajaran.(1)

\section{Permendiknas Nomor 19 Tahun 2007}

Pasal 1 (1) Setiap satuan pendidikan wajib memenuhi standar pengelolaan pendidikan yang berlaku secara nasional. (2) Standar pengelolaan pendidikan sebagaimana dimaksud pada ayat (1) tercantum dalam Lampiran Peraturan Menteri ini. Pasal 2 Peraturan Menteri ini mulai berlaku pada tanggal ditetapkan. Ditetapkan Jakarta 23 Mei 2007 Permendiksnas No.19 Tahun 2007 ini merupakan penejelasan dari PP No.19 Tahun 2005 mengenai standar pengelolaan. Permen ini membahas standardisasi ,penegelolaan pendidikan yang diselenggarakan oleh satuan pendidikan dasar dan menengah. Selain itu, Permendiknas ini merupakan penjabaran lebih rinci dari UU sistem pendidikan nasioanal. Secara garis besar, peraturan ini hanya memuat dua pasal. Selebihnya, penejelasan dari permen ini ada pada bagaian lampiran. Dalam lampiran permendiknas ini ada enam poin penting yang arus diperhatikan oleh setiap satuan pendidikan dasar dan menengah. Enam poin tersebut adalah

7. Perencanaan Program

8. Pelaksanaan Rencana Kerja

9. Pengawasan dan Evaluasi

10. Kepemimpinan Sekolah/Madrasah ${ }^{(1)}$

11. Sistem Informasi Manajemen 
12. Penilaiaan Khusus Dalam Permendiknas ini terkandung beberapa poinpenting, diantaranya :

\section{Perencanaan Program}

Perencanaan program dalam pengelolaan pendidikan meliputi

Pembuatan Visi, Misi, Tujuan, dan rencana Kerja.

\section{f. Visi sekolah/madrasah:}

Visi merupakan gambaran tentang masa depan (future) yang realistik dan ingin diwujudkan dalam kurun waktu tertentu.

Visi adalah pernyataan yang diucapkan atau ditulis hari ini, yang merupakan proses manajemen saat ini yang menjangkau masa yang akan datang (Akdon, 2006:94). Hax dan Majluf dalam Akdon (2006:95) menyatakan bahwa visi adalah pernyataan yang merupakan sarana untuk: Bagi sekolah .Visi adalah imajinasi moral yang menggambarkan profil sekolah yang diinginkan di masa datang. Imajinasi ke depan seperti itu akan selalu diwarnai oleh peluang dan tantangan yang diyakini akan terjadi di masa datang. Dalam menentukan visi tersebut, sekolah harus memperhatikan perkembangan dan tantangan masa depan.

Visi sekolah menurut Permendiknas No 19 Tahun 2007 arus memenuhi kritria sebagai berikut:

7. dijadikan sebagai cita-cita bersama warga sekolah/madrasah dan segenap pihak yang berkepentingan pada masa yang akan datang;

8. mampu memberikan inspirasi, motivasi, dan kekuatan pada warga sekolah/madrasah dan segenap pihak yang berkepentingan;

9. dirumuskan berdasar masukan dari berbagai warga sekolah/madrasah dan pihak-pihak yang berkepentingan, selaras dengan visi institusi di atasnya serta visi pendidikan nasional;

10. diputuskan oleh rapat dewan pendidik yang dipimpin oleh kepala sekolah/madrasah dengan memperhatikan masukan komite sekolah/madrasah;

11. disosialisasikan kepada warga sekolah/madrasah dan segenap pihak yang berkepentingan;

12. ditinjau dan dirumuskan kembali secara berkala sesuai dengan perkembangan dan tantangan di masyarakat ${ }^{(2)}$

\section{g. Misi Sekolah /Madrasah}


Misi adalah pernyataan mengenai hal-hal yang harus dicapai organisasi bagi pihak-pihak yang berkepentingan di masa datang (Akdon, 2006: 97). Pernyataan misi mencerminkan tentang penjelasan produk atau pelayanan yang ditawarkan. Misi merupakan tindakan atau upaya untuk mewujudkan visi. Jadi misi merupakan penjabaran visi dalam bentuk rumusan tugas, kewajiban, dan rancangan tindakan yang dijadikan arahan untuk mewujudkan visi. Dengan kata lain, misi adalah bentuk layanan untuk memenuhi tuntutan yang dituangkan dalam visi dengan berbagai indikatornya.

Misi sekolah menurut Permendiknas No.19 tahun 2007 harus memenuhi kriteria:

10. memberikan arah dalam mewujudkan visi sekolah/madrasah sesuai dengan tujuan pendidikan nasional;

11. merupakan tujuan yang akan dicapai dalam kurun waktu tertentu;

12. menjadi dasar program pokok sekolah/madrasah;

13. menekankan pada kualitas layanan peserta didik dan mutu lulusan yang diharapkan oleh sekolah/madrasah;

14. memuat pernyataan umum dan khusus yang berkaitan dengan program sekolah/madrasah;

15. memberikan keluwesan dan ruang gerak pengembangan kegiatan satuansatuan unit sekolah/madrasah yang terlibat;

16. dirumuskan berdasarkan masukan dari segenap pihak yang berkepentingan termasuk komite sekolah/madrasah dan diputuskan oleh rapat dewan pendidik yang dipimpin oleh kepala sekolah/madrasah

17. disosialisasikan kepada warga sekolah/madrasah dan segenap pihak yang berkepentingan;

18. ditinjau dan dirumuskan kembali secara berkala sesuai dengan perkembangan dan tantangan di masyarakat

\section{h. Tujuan Sekolah /Madrasah}

Tujuan menggambarkan arahan yang jelas bagi sekolah. Perumusan tujuan akan strategi/perlakuan, arah kebijakan dan program suatu sekolah. Oleh karena itu perumusan tujuan harus memberikan ukuran lebih spesifik dan akuntabel. . ${ }^{\text {(2) }}$

Perumusan tujuan menurut Permendiknas no.19 Tahun 2007 harus memenuhi kriteria sebagai berikut :

6) menggambarkan tingkat kualitas yang perlu dicapai dalam jangka menengah (empat tahunan); 
7) mengacu pada visi, misi, dan tujuan pendidikan nasional serta relevan dengan kebutuhan masyarakat;

8) mengacu pada standar kompetensi lulusan yang sudah ditetapkan oleh sekolah/madrasah dan Pemerintah;

9) mengakomodasi masukan dari berbagai pihak yang berkepentingan termasuk komite sekolah/madrasah dan diputuskan oleh rapat dewan pendidik yang dipimpin oleh kepala sekolah/madrasah;

10) disosialisasikan kepada warga sekolah/madrasah dan segenap pihak yang berkepentingan.

\section{i. Program/ Rencana Kerja Sekolah / Madrasah}

Program merupakan implementasi dari visi, misi dan tujuan. Program yang dimaksudkan dalam makalah ini adalah program operasional. Program operasional didefinisikan sebagai kumpulan kegiatan yang dihimpun dalam satu kelompok yang sama secara sendiri-sndiri atau bersama-sama untuk mencapai tujuan dan sasaran (Kdon, 2006:135). Program merupakan kumpulan kegiatan nyata, sistematis dan terpadu, dilaksanakan oleh satu instansi pemerintah atau lebih ataupun dalam rangka kerja sama dengan masyarakat atau yang merupakan partisipasi aktif masyarakat guna mencapai tujuan dan sasaran yang telah ditetapkan.Perumusan program kerja sekolah berdasarkan atas perumusan visi, misi, tujuan, sasaran, strategi dan kebijakan yang telah ditetapkan. Dalam merumuskan program kerja sekolah, ada beberapa hal yang perlu diperhatikan

a) Sekolah/Madrasah membuat:

- rencana kerja jangka menengah yang menggambarkan tujuan yang akan dicapai dalam kurun waktu empat tahun yang berkaitan dengan mutu lulusan yang ingin dicapai dan perbaikan komponen yang mendukung peningkatan mutu lulusan;

- rencana kerja tahunan yang dinyatakan dalam Rencana Kegiatan dan Anggaran Sekolah/Madrasah (RKA-S/M) dilaksanakan berdasarkan rencana jangka menengah

b) Rencana kerja jangka menengah dan tahunan sekolah/madrasah:

- disetujui rapat dewan pendidik setelah memperhatikan pertimbangan dari komite sekolah/madrasah dan disahkan berlakunya oleh dinas pendidikan kabupaten/kota. Pada sekolah/madrasah swasta rencana kerja ini disahkan berlakunya oleh penyelenggara sekolah/madrasah; 
- dituangkan dalam dokumen yang mudah dibaca oleh pihak-pihak yang terkait.

c) Rencana kerja empat tahun dan tahunan disesuaikan dengan persetujuan rapat dewan pendidik dan pertimbangan komite sekolah/madrasah.

d) Rencana kerja tahunan dijadikan dasar pengelolaan sekolah/madrasah yang ditunjukkan dengan kemandirian, kemitraan, partisipasi, keterbukaan, dan akuntabilitas.

e) Rencana kerja tahunan memuat ketentuan yang jelas mengenai:

- kesiswaan;

- kurikulum dan kegiatan pembelajaran;

- pendidik dan tenaga kependidikan serta pengembangannya;

- sarana dan prasarana;

- $\quad$ keuangan dan pembiayaan;

- budaya dan lingkungan sekolah;

- peranserta masyarakat dan kemitraan; ${ }^{(3)}$

- rencana-rencana kerja lain yang mengarah kepada peningkatan dan pengembangan mutu.

\section{j. Pelaksanan Program}

Pelaksanaan Rencana Kerja Sekolah/Madrasah meliputi seluruh bidang pelaksanaan operasional sekolah, meliputi: bidang kesiswaan, kurikulum dan kegiatan pembelajaran, pendidik dan tenaga kependidikan, sarana dan prasarana, keuangan dan pembiayaan, budaya dan lingkungan sekitar serta peran serta masyarakat dan kemitraan sekolah. Seluruh bidang tersebut diselenggarakan dan dikelola oleh satuan pendidikan yang dibentuk dalam struktur organisasi sekolah/madrasah. Struktur organisasi sekolah terdiri dari: semua pimpinan, pendidik, dan tenaga kependidikan yang mempunyai uraian tugas, wewenang, dan tanggung jawab yang jelas tentang keseluruhan penyelenggaraan dan administrasi sekolah.(3)

Pelaksanaan rencana kerja/kegiatan sekolah dilaksanakan berdasarkan rencna kerja tahunan oleh penanggung jawab kegiatan. Berikut ini beberapa pelaksanaan kegiatan sekolah yang dilaksanakan berdasarkan bidang garapannya, meliputi:

\section{Bidang Kesiswaan}



a) Menetapkan petunjuk pelaksanaan operasional mengenai proses penerimaan peserta didik.
b) Memberikan layanan konseling kepada peserta didik.
c) Melaksanakan kegiatan ekstra dan nonkurikuler untuk para peserta didik.
d) Melakukan pembinaan prestasi unggulan.
e) Melakukan pelacakan terhadap alumni.

\section{Bidang Kurikulum dan Kegiatan Pembelajaran}
a) Menyusun KTSP dan jadwal berdasarkan kalender pendidikan.
b) Menyusun dan mengembangkan program pembelajaran berdasarkan standar kompetensi dan kompetensi dasar yang ditetapkan.
c) Menyusun program penilaian hasil belajar peserta didik.
d) Menyusun dan menetapkan peraturan akademik.

\section{Bidang Pendidik dan Tenaga Kependidikan}
a) Menyusun program pendayagunaan pendidik dan tenaga kependidikan.
b) Mengangkat pendidik dan tenaga kependidikan tambahan yang dilaksanakan berdasarkan ketentuan yang telah ditetapkan oleh penyelenggara sekolah.

\section{Bidang Sarana dan Prasarana}
a) Menetapkan kebijakan program secara terttulis mengenai pengelolaan sarana dan prasarana.
b) Merencanakan, mengadakan, memelihara sarana dan prasarana yang ada di sekolah.
c) Menyusun skala prioritas pengembangan fasilitas pendidikan sesuai dengan tujuan pendidikan dan kurikulum.(3)

\section{Bidang Keuangan dan Pembiayaan}

Menyusun pedoman pengelolaan biaya investasi dan operasional yang mengacu pada standar pembiayaan.

\section{Bidang Budaya dan Lingkungan Sekolah}

a) Menciptakan suasana, iklim, dan lingkungan pendidikan yang kondusif untuk pembelajaran yang efisien dalam prosedur pelaksanaan.

b) Menetapkan pedoman tata tertib/peraturan sekolah.

c) Menetapkan kode etik warga sekolah.

15. Bidang Humas/Peran serta Masyarakat dan Kemitraan Sekolah 
Sekolah menjalin kemitraan dan kerja sama dengan masyarakatt dan lembaga lain untuk mendukung program pelaksanaan kegiatan sekolah dalam rangka pengelolaan pendidikan.

\section{Pengawasan dan Evaluasi}

Pengawasan dapat diartikan sebagai proses kegiatan monitoring untuk meyakinkan bahwa semua kegiatan organisasi terlaksana seperti yang direncanakan dan sekaligus juga merupakan kegiatan untuk mengoreksi dan memperbaiki bila ditemukan adanya penyimpangan yang akan mengganggu pencapaian tujuan (Robbins 1997).

Sekolah harus objektif, bertanggung jawab dan berkelanjutan dalam melakukan pengawasan. Pengawasan meliputi pemantauan, supervise, evaluasi, pelaporan dan tindak lanjut hasil pengawasan. Pemantauan dilakukan oleh komite sekolah, sedangkan supervise dilakukan secara teratur dilakukan oleh kepala sekolah . guru melaporkan hasil evaluasi dan penilaian sekurang-kurangnya kepada kepala sekolah.

Setiap pihak yang menerima laporan hasil pengawasan harus menindaklanjuti setiap laporan yang diterimanya dan menggunakan hasil pemantauan atau pengawasan tersebut untuk memperbaiki kinerja sekolah dan sebagai sarana pendidikan.

\section{Program Evaluasi}

Jenis-Jenis Evaluasi:

1.Evaluasi diri adalah evaluasi yang dilakukan pihak sekolah untuk menilai kinerja sekolah itu sendiri. Pihak sekolah menetapkan prioritas indicator untuk mengukur, menilai kinerja dan melakukan perbaikan dalam rangka pelaksaaan Standar Nasional Pendidikan. Evaluasi diri atau evaluasi sekolah dilakukan secara periodic berdasarkan pada data dan informasi yang sahih ${ }^{(3)}$

2. Evaluasi dan pengembangan KTSP adalah proses yang dilakukan secara komprehensif dan flexible agar bisa menghadapi kemajuan ilmu pengetahuan dan teknologi yang mutakhir dan bersifat menyeluruh yang artinya melibatkan semua pihak

3. Evaluasi pendayagunaan pendidik dan tenaga pendidik meliputi kesesuaian penugasan dengan keahlian, keseimbangan beban kerja dan kinerja pendidik dan tenaga kependidikan dalam pelaksaan tugas. Evaluasi harus emperhatikan pencapaian prestasi dan perubahan perubahan peserta didik. 
Akreditasi sekolah merupakan suatu kegiatan yang dilakukan oleh pemerintah atau lembaga yang berwenang untuk menentukan tingkat kelayakan suatu sekolah/madrasah berdasarkan kriteria yang telah ditetapkan, sebagai bentuk akuntabilitas publik yang dilakukan secara obyektif, adil, transparan, dan komprehensif dengan menggunakan instrumen dan kriteria yang mengacu kepada Standar Nasional Pendidikan.

4. Kepemimpinan Sekolah

Secara umum kepemiminan dapat dirumuskan sebagai berikut. "Kepemimpinan berarti kemauan dan kesiapan yang dimiliki oleh seseorang untuk dapat memengaruhi, mendorong, mengajak, menuntun, menggerakan, mengarahkan dan kalau perlu memaksa orang atau kelompok agar menerima pengaruh tersebut dan selanjutnya berbuat sesuatu yang dapat menbantu tercapainya suatu tujuan tertentu ang telah ditetapkan.

Kepemimpinan adalah proses mempengaruhi kegiatan-kegiatan kelompok yang diorganisir menuju kepada penentuan dan pencapaian tujuan (Ralp M Stogdil). Sedangkan menurut Sondang P. Siagian, kepemimpinan mrupakan motor atau daya penggerak daripada semua sumber-sumber, dan alat yang tersedia bagi suatu organisasi. ${ }^{(3)}$

\section{E. Fungsi Pemimpin}

Fungsi utama pemmpin pendidikan adalah kelompok untuk belajar memutuskan dan bekerja, antara lain:

1) Pemimpin membantu terciptanya suasana persaudaraan, kerjasama dengan penuh rasa kebebasan.

2) Pemimpin membatu kelompok untuk menorganisir diri yaitu ikut serta dalam memberikan rangsangan dan bantuan kepada kelompok dalam menetapkan dan menjelaskan tujuan. ${ }^{(3)}$

3) Pemimpin membantu kelompok dalam menetapkan prosedur kerja, yaitu membantu kelompok dalam menganalisis situasi untuk kemudian mentapkan prosedur mana yang paling praktis dan efektif. ${ }^{(3)}$

4) Pemimpin bertanggung jawb dalam mengambil keputusan bersama dengan kelompok. Pemimpin member kesempatan kepada kelompok untuk belajar dari pengalaman. Pemimpin mempunyai tanggung jawab untuk melatih kelompok menyadari proses dan isi pekerjaan yang dilakukan dan beran menilai hasilnya secara jujur dan objektif. 


\section{F. Tugas dan Kewajiban Pemimpin sekolah/madrasah :}

1. Menjabarkan visi ke dalam misi target mutu yang akan dicapai

2. Merumuskan tujuan dan target mutu yang akan dicapai

3. Menganalisis tnatangan, peluang, kekuatan dan kelemahan sekolah dan madrasah

4. Membuat rencana kerja strategis dan rencan kerja tahunan untuk pelaksanaan peningkatan mutu

5. Bertanggung jawab dalam membuat keputusan anggaran sekolah dan madrasah

6. Melibatkan guru, komite sekolah dalam pengambilan keputusan penting sekolah/madrasah. Dalam hal ini sekolah / madrasah swasta, pengambilan keputusan tersebut harus melibatkan penyelenggara sekolah dan madrasah.

7. Berkomunikasi untuk menciptakan dukungan intensif dari orang tua peserta didikdan masyarakat

8. Menjaga dan meningkatkan motivasi kerja pendidikan dan tenaga kependidikan dengan menggunakan sistem pemberian penghargaan atas prestasi dan sangsi atas pelanggaran peraturan dank kode etik

9. Menciptakan lingkungan pembelajaran yang efektif bagi peserta didik

10. Bertanggungjawab atas perencanaan partisifatif mengenai pelaksanaan dan kurikulum

11. Melaksanakan dan merumuskan program supervise, serta memanfaatkan hasil supervise untuk meningkatkan kinerja sekolah dan madrasah

12. Meningkatkan mutu pendidikan ${ }^{(3)}$

13. Member teladan dan menjaga nama baik lembaga, profesi dan kedudukan sesuaidengan kepercayaan yang diberikan kepadanya

14. Memfasilitasi pengembanga, penyebarluasan dan pelaksanaan visi pembelajaran yang dikomunikasikan dengan baik dan didukung oleh komunitas sekolah/madrasah ${ }^{(3)}$

15. Membantu, membina dan mempertahankan lingkungan sekolah / madrasah dan progam pembelajaran yang kondusif bagi proses belajar peserta didik dan pertumbuhan profesional para guru dan tenaga kependidikan

16. Menjamin manajemen organisasi dan pengoperasian sumber daya sekolah/madrasah untuk menciptakan lingkungan belajar yang aman, sehat efisien dan efektif 
17. Menjalin kerjasama dengan orang tua peserta didik dan masyarakat dan komite sekolah /madrasah menanggapi kepentingan dan kebutuhan komunitas yang beragam dan memobilisasi sumber daya masyrakat

18. Member contoh/teladan/tindakan yang bertanggung jawab ${ }^{(3)}$

\section{Kesimpulan}

pengelolaan pendidikan sebagai upaya untuk menerapkan kaidah-kaidah adiministrasi dalam bidang pendidikan. Pengelolaan pendidikan meliputi kegiatan perencanaan, pengorganisasian, pengarahan, pengawasan dan pengembangan. Pengelolaan adalah suatu proses perencanaan, pengorganisasian, kepemimpinan dan pengendalian upaya anggota organisasi dimana keempat proses tersebut mempunyai fungsi masing-masing untuk mencapai suatu tujuan organisasi.

\section{Evaluasi}

Pilihlah jawaban yang bener untuk setiap dibawah ini dengan membubuhkan tanda silang (x) pada alternatif-alternatif jawaban yang ada.

1.Ada berapa Perencanaan Program .
A. 5 program
B. 6 program
C. 4 program
D. 3 program
E. 7 program

2. Perumusan tujuan menurut Permendiknas no.19 Tahun 2007 harus memenuhi kriteria sebagai berikut ini .
A. menggambarkan tingkat kualitas yang perlu dicapai dalam jangka menengah (empat tahunan).
B. mengacu pada visi, misi, dan tujuan pendidikan nasional serta relevan dengan kebutuhan masyarakat.
C. mengacu pada standar kompetensi lulusan yang sudah ditetapkan oleh sekolah/madrasah dan Pemerintah.
D. semua jawaban diatas salah.
E. semua jawaban benar. 
3. Fungsi utama pemmpin pendidikan adalah kelompok untuk belajar memutuskan dan bekerj kecuali .

A. Pemimpin membantu terciptanya suasana persaudaraan, kerjasama dengan penuh rasa kebebasan

B. Pemimpin membatu kelompok untuk menorganisir diri yaitu ikut serta dalam memberikan rangsangan dan bantuan kepada kelompok dalam menetapkan dan menjelaskan tujuan.

C. Pemimpin membantu kelompok dalam menetapkan prosedur kerja, yaitu membantu kelompok dalam menganalisis situasi untuk kemudian mentapkan prosedur mana yang paling praktis dan efektif.

D. Menjabarkan visi ke dalam misi target mutu yang akan dicapai.

E. Semua jawaban benar.

4. Ada berapa poin Tugas dan Kewajiban Pemimpin sekolah/madrasah.
A. 11 poin
B. 12 poin
C. 15 poin
D. 18 poin
E. 13 poi

5. Menyusun program pendayagunaan pendidik dan tenaga kependidikan temasuk dalam bidang.
A. Bidang kebudayaan
B. Bidang tenaga
C. Bidang kependidikan
D. Bidang keilmuan
E. Bidang pendidik dan bidang kependidikan

6. Menetapkan pedoman tata tertib/peraturan sekolah
A. Bidang budaya
B. Bidang lingkungan
C. Bidang budaya dan lingkungan sekolah
D. Bidang keilmuan
E. Bidang pendidik

7. Menyusun pedoman pengelolaan biaya investasi dan operasional yang mengacu pada standar pembiayaan. 

A. Bidang keuangan
B. Bidang pembiyayan
C. Bidang kebudayaan
D. Bidang administrasi
E. Bidang keuangan dan pembiyayaan

8. Rencana kerja tahunan dijadikan dasar pengelolaan sekolah/madrasah yang ditunjukkan dengan.
A. kemandirian,
B. kemitraan
C. partisipasi
D. keterbukaan, dan akuntabilitas
E. Semua jawaban benar

9. Memberikan layanan konseling kepada peserta didik. termasuk kedalam bidang.
A. Bidang keuangan
B. Bidang kebudayaan
C. Bidang keuangan dan pembiyayan
D. Bidang lingkungan
E. Bidang kesiswaan

10. Pengawasan meliput kecuali
A. pemantauan
B. supervise
C. evaluasi, pelaporan
D. tindak lanjut hasil pengawasan
E. penglihatan

\section{Latihan-latihan}

1. Sebutkan beberapa pelaksanaan kegiatan sekolah yang dilaksanakan berdasarkan bidang garapannya, meliputi.

2. Dalam lampiran permendiknas ini ada enam poin penting yang arus diperhatikan sebutkan enam pon tersebut.

3. Sebutkan beberapa Misi sekolah menurut Permendiknas No.19 tahun 2007 harus memenuhi kriteria.

4. Perencanaan program dalam pengelolaan pendidikan meliputi . 
5. Keputusan Kepala Dinas Kota Cimahi no. 800/1330-Disdik/2009 tentang Pedoman.

\section{BAB X \\ PEMBIAYAAN PENDIDIKAN (PERATURAN PEMERINTAH 48/2008)}

Peraturan Pemerintah yang ditetapkan oleh presiden Susilo Bambang Yudhoyono di Jakarta pada tanggal 4 Juli 2008 ini sedikit banyak telah menyebabkan adanya perubahan yang sangat mendasar bagi pelaksanaan pendidikan dalam rangka mengemban amanat pendiri bangsa untuk mencerdaskan kehidupan bangsa. Bagi kalangan pejabat pemerintah dibidang pendidikan ditingkat pusat maupun regional hal ini mungkin tidak begitu menyulitkan, akan tetapi dikalangan pejabat bidang pendidikan ditingkat kabupaten maupun kota akan sangat memerlukan ekstra hati-hati mengingat beliau beliau inilah yang langsung berhubungan dengan sekolah-sekolah dibawah kordinasinya. Pendanaan pendidikan menjadi tanggung jawab bersama antara pemerintah, pemerintah daerah, dan masyarakat diantaranya :

a. Penyelenggara atau satuan pendidikan yang didirikan masyarakat.

b. Peserta didik, orang tua atau wali peserta didik.

c. Pihak lain yang mempunyai perhatian dan peranan dalam bidang pendidikan.

Penjabaran terhadap peraturan pemerintah RI nomor 48 tahun 2008 tentang pendanaan pendidikan sebagai dasar pelaksanaan ketentuan Pasal 46 ayat (3), Pasal 47 ayat (3), Pasal 48 ayat (2), dan Pasal 49 ayat (5) Undang-Undang Nomor 20 Tahun 2003 tentang Sistem Pendidikan Nasional dan Pasal 5 ayat (2) Undang-Undang Dasar Negara Republik Indonesia Tahun 1945;

Dalam peraturan pemerintah 48/2008 Pasal 3, Pasal 4, dan Pasal 5 menguraikan secara terperinci mengenai definisi dan komponen biaya pendidikan yang merupakan tanggung jawab pemerintah dialokasikan dalam APBN dan yang merupakan tanggung jawab pemerintah daerah dialokasikan dalam APBD sesuai dengan sistem penganggaran dalam peraturan perundang-undangan.

Adapun komponen biaya pendidikan adalah biaya satuan pendidikan, biaya penyelenggaraan dan/ Atau pengelolaan pendidikan serta biaya pribadi peserta didik. 
Biaya satuan pendidikan merupakan biaya penyelenggaraan pendidikan pada tingkat satuan pendidikan, meliputi :

1.1. Biaya investasi, yang terdiri atas :

a. Biaya investasi lahan pendidikan untuk satuan pendidikan pelaksana program wajib belajar dan bukan program wajib belajar, baik formal maupun nonformal yang menjadi tanggungjawab pemerintah / pemerintah daerah dianggarkan dalam anggaran pemerintah / pemerintah daerah.

b. Biaya investasi selain lahan pendidikan untuk satuan pendidikan pelaksana program wajib belajar dan bukan program wajib belajar, baik formal maupun nonformal yang menjadi tanggungjawab pemerintah / pemerintah daerah dianggarkan dalam anggaran pemerintah / pemerintah daerah.

c. Biaya investasi selain lahan untuk satuan pendidikan yang bukan pelaksana program wajib belajar, baik formal maupun nonformal, yang diselenggarakan oleh Pemerintah / Pemerintah daerah menjadi tanggung jawab Pemerintah / Pemerintah daerah masyarakat.

1.2. Biaya operasi, yang terdiri atas :

a. Biaya personalia baik formal maupun nonformal, bagi PNS di sektor pendidikan menjadi tanggungjawab pemerintah / pemerintah daerah meliputi :

1. Gaji pokok bagi pegawai pada satuan pendidikan dianggarkan dalam anggaran pemerintah / pemerintah daerah;

2. Tunjangan yang melekat pada gaji bagi pegawai pada satuan pendidikan dianggarkan dalam anggaran pemerintah / pemerintah daerah;

3. Tunjangan struktural bagi pejabat struktural pada satuan pendidikan dianggarkan dalam anggaran pemerintah / pemerintah daerah;

4. Tunjangan fungsional bagi pejabat fungsional di luar guru dianggarkan dalam anggaran pemerintah / pemerintah daerah dan dosen dianggarkan dalam anggaran pemerintah;

5. Tunjangan fungsional atau subsidi tunjangan fungsional bagi guru dianggarkan dalam anggaran pemerintah / pemerintah daerah dan dosen dianggarkan dalam anggaran pemerintah;

6. Tunjangan profesi bagi guru dan dosen dianggarkan dalam anggaran pemerintah;

7. Tunjangan khusus bagi guru dan dosen dianggarkan dalam anggaran pemerintah; 
8. Konsekuensi anggaran dari maslahat tambahan bagi guru PNS sektor pendidikan dianggarkan dalam anggaran pemerintah / pemerintah daerah dan guru non PNS maupun dosen dianggarkan dalam anggaran pemerintah; dan

9. Tunjangan kehormatan bagi dosen yang memiliki jabatan profesor atau guru besar dianggarkan dalam anggaran pemerintah.

b. Biaya non personalia, Biaya non personalia untuk satuan pendidikan pelaksana program wajib belajar yang menjadi tanggungjawab pemerintah / pemerintah daerah dianggarkan dalam anggaran pemerintah / pemerintah daerah.

Biaya non personalia untuk satuan pendidikan yang bukan pelaksana program wajib belajar yang menjadi tanggungjawab pemerintah / pemerintah daerah dianggarkan dalam anggaran pemerintah / pemerintah daerah dan masyarakat

c. Bantuan biaya pendidikan

Bantuan biaya pendidikan adalah dana pendidikan yang diberikan kepada peserta didik yang orang tua atau walinya tidak mampu membiayai pendidikannya, berupa :

a. Pemerintah dan pemerintah daerah sesuai kewenangannya memberi bantuan biaya pendidikan atau beasiswa kepada peserta didik yang orang tua atau walinya tidak mampu membiayai pendidikannya.

b. Pemerintah dan pemerintah daerah sesuai kewenangannya dapat memberi beasiswa kepada peserta didik yang berprestasi.

c. Pemberian bantuan biaya pendidikan siswa mencakup sebagian atau seluruh biaya pendidikan yang harus ditanggung peserta didik, termasuk biaya pribadi peserta didik

Beasiswa adalah dana pendidikan yang diberikan kepada peserta didik yang orang tua atau walinya tidak mampu membiayai pendidikannya. Pemberian beasiswa mencakup sebagian atau seluruh biaya pendidikan yang harus ditanggung peserta didik, termasuk biaya pribadi peserta didik

Biaya Penyelenggaraan Dan/ Atau Pengelolaan Pendidikan merupakan biaya penyelenggaraan dan/atau pengelolaan pendidikan oleh Pemerintah, pemerintah provinsi, pemerintah kabupaten/kota, atau penyelenggara/satuan pendidikan yang didirikan masyarakat, meliputi :

Biaya investasi, yang terdiri atas :

a. Biaya investasi lahan pendidikan yang diselenggarakan pemerintah / pemerintah daerah dianggarkan dalam anggaran pemerintah/pemerintah daerah 
b. Biaya investasi selain lahan pendidikan yang diselenggarakan pemerintah/pemerintah daerah dianggarkan dalam anggaran pemerintah/pemerintah daerah Biaya operasi, yang terdiri atas :

a. Biaya personalia baik fomal maupun nonformal, bagi PNS di sektor pendidikan menjadi tanggung jawab pemerintah / pemerintah daerah dialokasi dalam anggaran pemerintah, meliputi :

1. Gaji pokok;

2. Tunjangan yang melekat pada gaji;

3. Tunjangan struktural bagi pejabat struktural; dan

4. Tunjangan fungsional bagi pejabat fungsional.

Tanggung jawab Pemerintah terhadap pendanaan biaya personalia bukan PNS di sektor pendidikan dianggarakan dalam anggaran pemerintah / pemerintah daerah meliputi:

1. Subsidi tunjangan fungsional bagi dosen tetap yang ditugaskan oleh pemerintah / pemerintah daerah atau penyelenggara/satuan pendidikan yang didirikan masyarakat;

2. Subsidi tunjangan fungsional bagi guru tetap madrasah dan pendidikan keagamaan formal yang ditugaskan oleh Pemerintah atau penyelenggara/satuan pendidikan yang didirikan masyarakat;

3. Tunjangan profesi bagi guru yang ditugaskan oleh Pemerintah atau dosen yang ditugaskan oleh Pemerintah atau penyelenggara/satuan pendidikan yang didirikan masyarakat; Tunjangan khusus bagi guru atau dosen yang ditugaskan di daerah khusus oleh Pemerintah;

4. Tunjangan khusus bagi guru atau dosen yang ditugaskan di daerah khusus oleh penyelenggara/satuan pendidikan yang didirikanmasyarakat yang memperoleh persetujuan dari Pemerintah;

5. Tunjangan kehormatan bagi dosen tetap yang memiliki jabatan profesor atau guru besar yang ditugaskan oleh Pemerintah atau penyelenggara/satuan pendidikan yang didirikan masyarakat;

6. Honorarium bagi guru honor yang ditugaskan oleh pemerintah / pemerintah daerah; dan 
7. Honorarium bagi personalia pendidikan kesetaraan, keaksaraan, dan pendidikannonformal lainnya yang diselenggarakan oleh pemerintah /pemerintah daerah atau masyarakat atas inisiatif Pemerintah.

Biaya non personalia yang menjadi tanggungjawab pemerintah / pemerintah daerah dianggarkan dalam anggaran pemerintah / pemerintah daerah

\subsection{Biaya Pribadi Peserta Didik}

Biaya pribadi peserta didik merupakan biaya personal yang meliputi biaya pendidikan yang harus dikeluarkan oleh peserta didik untuk bisa mengikuti proses pembelajaran secara teratur dan berkelanjutan

-Pendanaan biaya investasi selain lahan untuk satuan pendidikan yang bukan pelaksana program wajib belajar, baik formal maupun nonformal, yang diselenggarakan oleh Pemerintah / Pemerintah daerah menjadi tanggung jawab Pemerintah / Pemerintah daerah masyarakat.

-Pemerintah atau pemerintah daerah dapat mendanai investasi dan/atau biaya operasi satuan pendidikan dalam bentuk hibah atau bantuan sosial sesuai peraturan perundang-undangan.

-Pemerintah dapat memberikan hibah kepada daerah atau sebaliknya, untuk kepentingan pendidikan sesuai peraturan perundang-undangan.

-Pemerintah atau pemerintah daerah dapat memberikan hibah kepada masyarakat atau sebaliknya, untuk kepentingan pendidikan sesuai peraturan perundangundangan.

-Pemangku kepentingan pendidikan, dan pihak asing dapat membantu pendanaan biaya satuan pendidikan yang diselenggarakan Pemerintah / Pemerintah daerah -Penerimaan, penyimpanan, dan penggunaan sumbangan pendidikan oleh masyarakat di luar penyelenggara dan satuan pendidikan diaudit oleh akuntan publik, diumumkan secara transparan di media cetak berskala nasional, dan dilaporkan kepada Menteri apabila jumlahnya lebih besar dari jumlah tertentu yang ditetapkan oleh Menteri

-Sumber pendanaan pendidikan ditentukan berdasarkan prinsip keadilan, kecukupan, dan keberlanjutan

-Seluruh dana satuan pendidikan yang diselenggarakan oleh Pemerintah / pemerintah daerah dikelola sesuai sistem anggaran Pemerintah pemerintah daerah. 
-Anggaran belanja untuk melaksanakan fungsi pendidikan pada sektor pendidikan dalam anggaran pendapatan dan belanja negara/daerah setiap tahun anggaran sekurang-kurangnya dialokasikan $20 \%$ (dua puluh perseratus) dari belanja negara/daerah

-Pemeriksaan penerimaan dan penggunaan dana pendidikan dalam rangka pengawasan penerimaan dan penggunaan dana pendidikan Pemerintah dilakukan sesuai dengan ketentuan peraturan perundang-undangan

-Dana pendidikan Pemerintah dan pemerintah daerah serta satuan pendidikan yang diselenggarakan Pemerintah dan pemerintah daerah dipertanggungjawabkan sesuai dengan ketentuan peraturan perundang-undangan

-Dana pendidikan dari Pemerintah diberikan kepada pemerintah daerah dalam bentuk hibah (tidak termasuk dalam dana dekonsentrasi, dana tugas pembantuan dan dana alokasi khusus bidang pendidikan) dan dituangkan dalam naskah perjanjian hibah daerah antara Menteri Keuangan atau kuasanya dengan kepala daerah, biaya penyaluran dananya tidak boleh dibebankan kepada penerima hibah dan penerima hibah wajib melaporkan jumlah dana yang diterima dan penggunaannya kepada Menteri Pendidikan dan Menteri Keuangan. [1]

\section{B. Sumber Pendanaan Pendidikan}

Dana pendidikan satuan pendidikan yang diselenggarakan oleh Pemerintah dapat bersumber

dari:

a. Anggaran Pemerintah;

b. Bantuan pemerintah daerah;

c. Pungutan dari peserta didik atau orang tua/walinya yang dilaksanakan sesuai peraturan perundang-undangan;

d. Bantuan dari pemangku kepentingan satuan pendidikan di luar peserta didik atau orang tua/walinya;

e. Bantuan dari pihak asing yang tidak mengikat;

f. Sumber lainnya yang sah.

Sumber Pendanaan Pendidikan memiliki prinsip diantaranya :

1. Prinsip keadilan bahwa besarnya pendanaan pendidikan oleh Pemerintah, pemerintah daerah, dan masyarakat disesuaikan dengan kemampuan masingmasing. 
2. Prinsip kecukupan berarti bahwa pendanaan pendidikan cukup untuk membiayai

Penyelenggaraan pendidikan yang memenuhi Standar Nasional Pendidikan.

3. Prinsip keberlanjutan berarti bahwa pendanaan pendidikan dapat digunakan secara berkesinambungan untuk memberikan layanan pendidikan yang memenuhi standar Nasional Pendidikan.

\section{Prinsip umum pengelolaan dana pendidikan}

1. Prinsip keadilan memberikan akses pelayanan pendidikan yang seluas-luasnya dan merata kepada peserta didik atau calon peserta didik, tanpa membedakan latar belakang suku, ras, agama, jenis kelamin, dan kemampuan atau status sosial-ekonomi.

2. Prinsip efisiensi mengoptimalkan akses, mutu, relevansi, dan daya saing pelayanan pendidikan.

3. Prinsip transparansi, memenuhi asas kepatutan dan tata kelola yang baik oleh Pemerintah, pemerintah daerah, penyelenggara pendidikan yang didirikan masyarakat, dan satuan pendidikan sehingga:

a. Dapat diaudit atas dasar standar audit yang berlaku, dan menghasilkan opini audit wajar tanpa perkecualian; dan

b. Dapat dipertanggungjawabkan secara transparan kepada pemangku kepentingan pendidikan.

4. Prinsip akuntabilitas publik dengan memberikan pertanggungjawaban atas kegiatan yang dijalankan oleh penyelenggara atau satuan pendidikan kepada pemangku kepentingan pendidikan sesuai dengan peraturan perundangundangan.

\section{Pengalokasian dana pendidikan}

Anggaran belanja untuk melaksanakan fungsi pendidikan pada sektor pendidikan dalam

1.Anggaran pendapatan dan belanja negara setiap tahun anggaran sekurangkurangnya dialokasikan 20\% (dua puluh perseratus) dari belanja negara.

2. Anggaran belanja untuk melaksanakan fungsi pendidikan pada sektor pendidikan dalam

3. Anggaran pendapatan dan belanja daerah setiap tahun anggaran sekurangkurangnya dialokasikan 20\% (dua puluh perseratus) dari belanja daerah. 
4. Dana pendidikan dari Pemerintah dan/atau pemerintah daerah diberikan kepada satuan pendidikan dalam bentuk hibah sesuai dengan ketentuan peraturan perundang-undangan.

5. Dalam proses penyaluran dana pendidikan dari pemerintah dan/atau pemerintah daerah ke satuan pendidikan petugas dan/atau lembaga yang terlibat dalam penyaluran dana harus sudah menyalurkan dana tersebut secara langsung kepada satuan pendidikan dalam waktu paling lama 5 (lima) hari.

\section{Tanggung Jawab Pemerintah}

Tanggung jawab pendanaan pendidikan oleh pemerintah dan pemerintah daerah sebagaimana diatur dalam pasal 7 sampai dengan pasal 31 meliputi biaya investasi satuan pendidikan, biaya investasi penyelenggaraan dan/atau pengelolaan pendidikan, biaya operasi satuan pendidikan, biaya operasi penyelenggaraan dan/atau pengelolaan pendidikan, bantuan biaya pendidikan dan beasiswa serta pendanaan pendidikan di luar negeri.

Biaya Investasi satuan pendidikan dan biaya investasi penyelenggaraan dan/atau pengelolaan pendidikan yang merupakan tanggung jawab pemerintah akan meliputi beaya investasi lahan pendidikan dan biaya investasi selain lahan pendidikan. Sedang biaya operasi satuan pendidikan dan biaya operasi penyelenggaraan dan/atau pengelolaan pendidikan yang merupakan tanggung jawab pemerintah akan meliputi biaya personalia dan biaya non-personalia.

Demikian pula dengan bantuan biaya, beasiswa dan pendanaan pendidikan diluar negeri semuanya diatur dengan jelas dalam peraturan pemerintah nomor 48 tahun 2008 dengan disertai dengan ancaman pengenaan sangsi sesuai dengan peraturan perundang-undangan.

\section{Tanggung Jawab Masyarakat}

Tanggung jawab masyarakat dalam pendanaan pendidikan dapat dibagi dalam 2 (dua) katagori, yaitu tanggung jawab pendanaan pendidikan oleh penyelenggara atau satuan pendidikan yang didirikan masyarakat dan tanggung jawab pendanaan pendidikan oleh masyarakat diluar penyelenggara dan satuan pendidikan yang didirikan masyarakat. Komponen biaya pendidikan pada penyelenggara atau satuan pendidikan yang didirikan masyarakat akan meliputi biaya investasi satuan pendidikan, biaya investasi penyelenggaraan dan/atau 
pengelolaan pendidikan, biaya operasi satuan pendidikan, biaya operasi penyelenggaraan dan/atau pengelolaan pendidikan, bantuan biaya pendidikan dan beasiswa.

Sedangkan tanggung jawab masyarakat diluar penyelenggara satuan pendidikan yang didirikan masyarakat atau dengan kata lain tanggung jawab masyarakat selaku orangtua atau wali peserta didik akan meliputi biaya pribadi peserta didik, biaya investasi selain lahan yang diperlukan untuk menutupi kekurangan pendanaan, biaya personalia yang diperlukan untuk menutupi kekurangan pendanaan dan pendanaan sebagian dari biaya operasi pendidikan dalam rangka pengembangan sekolah yang biasanya dipungut berdasarkan musyawarah dan mufakat melalui Komite Sekolah.

\section{STANDAR NASIONAL PENDIDIKAN}

Dengan diberlakukannya Undang Undang Nomor 20 Tahun 2003 tentang Sistem Pendidikan Nasional dimana pada bab IX diatur jelas tentang perlu adanya standar nasional pendidikan yang meliputi standar isi, proses, kompetensi kelulusan, tenaga kependidikan, sarana dan prasarana, pengelolaan, pembiayaan dan penilaian pendidikan yang harus ditingkatkan secara berencana dan berkala. Standar Nasional Pendidikan ini digunakan sebagai acuan pengembangan kurikulum, tenaga kependidikan, sarana dan prasarana, pengelolaan dan pembeayaan dan sebagainya.

Dengan adanya maksud untuk mencapai standar nasional pendidikan tersebut, maka sangat dibutuhkan tambahan pembiayaan diluar kemampuan pemerintah maupun pemerintah daerah. Sehingga bagi sekolah yang memenuhi persyaratan diajukan untuk meningkatkan standar nasional pendidikannya, apakah itu Sekolah Standar Nasional (SSN) atau Sekolah Standar Internasional (SSI) diperlukan partisipasi masyarakat dan juga dunia usaha untuk mendanainya. Dengan dasar itulah Peraturan Pemerintah Nomor 48 Tahun 2008 juga masih mematok masyarakat untuk ikut mendanai pendidikan dengan ketentuan harus didasarkan pada perencanaan investasi dan/atau operasi yang jelas dan transparan serta dapat dipertanggung jawabkan sebagaimana diuraikan pada bab V pasal 50, pasal 51 dan pasal 52.

\section{SEKOLAHGRATIS, MUNGKINKAH ?}


Dengan memahami Peraturan Pemerintah Nomor 48 Tahun 2008, maka akan dapat dirumuskan secara sederhana apakah bisa menyelenggakan sekolah gratis hanya dengan alasan gaji guru sudah dinaikkan, adanya tunjangan sertifikasi dan dana Bantuan Operasional Sekolah (BOS) dinaikkan sebagaimana diharapkan oleh sebagian besar masyarakat.

Jawaban pertama BISA, dengan catatan bilamana pendanaan pendidikan yang menjadi tanggung jawab pemerintah dan pemerintah daerah (Propinsi dan Kabupaten/Kota) telah mencukupi semua kebutuhan dana untuk penyelenggaraan pendidikan pada satuan pendidikan. Sehingga masyarakat tidak ikut serta mendanai pendidikan sama sekali alias GRATIS, akan tetapi hal ini tentunya bertentangan dengan pasal 46 ayat (1) Undang Undang Nomor 20 Tahun 2003 tentang Sistem Pendidikan Nasional yang menyatakan bahwa pendanaan pendidikan menjadi tanggung jawab bersama antara pemerintah, pemerintah daerah dan masyarakat.

Jawaban kedua BISA, walaupun pendanaan pendidikan dari pihak pemerintah dan pemerintah daerah belum mencukupi semua kebutuhan dana penyelenggaraan pendidikan, dengan catatan pengelolaan pendidikannya akan jauh dibawah standar nasional pendidikan. Dan hal ini tentunya juga bertentangan dengan pasal 35 Undang Undang Nomor 20 tahun 2003 tentang Sistem Pendidikan Nasional.

Jawaban ketiga TIDAK BISA, karena pada tahun anggaran 2009 ini hanya pemerintah pusat yang berkewajiban mengalokasikan dana pendidikan sebesar 20\% dari Anggaran Pendapatan dan Belanja Nasioanl diluar gaji guru (PNS) sebagai konsekwensi keberhasilan Pengurus PGRI dalam uji materi Undang Undang tentang APBN terhadap Undang Undang Dasar Negara Republik Indonesia (lihat putusan Mahkamah Konstitusi Nomor 13/PUU-VI/2008). Sedangkan sebagian besar pemerintah propinsi dan pemerintah daerah diseluruh Indonesia masih belum siap, mengingat penyerapan anggaran untuk membayar gaji guru (PNS) sudah melampau $20 \%$.

\section{SOLUSI}

Sebagai solusi atas adanya dilema masalah pendanaan pendidikan tersebut, banyak kalangan mengajukan konsep subsidi silang yang artinya bagi orang yang tidak mampu tetap dapat menikmati pendidikan secara gratis. Sedangkan bagi orang yang mampu sebaiknya tetap dikenakan beaya sebagaimana dikehendaki 
dalam Peraturan Pemerintah Nomor 48 Tahun 2008. Namun semuanya berpulang kepada semua pihak yang berkepentingan dalam dunia pendidikan, baik pemerintah, pemerintah daerah, penyelenggara satuan pendidikan dan masyarakat dan/atau orangtua / wali peserta didik. [2]

\section{DAFTAR PUSTAKA}

https://darsyam.wordpress.com/2013/03/13/pp-48-tahun-2008-tentang-

pendanaan-pendidikan/

http://www.mediapendidikan.info/2010/03/mencoba-memahami-pp-no-48-

tahun-2008.html

Soal dan latihan

1. Jawablah Pertanyaan dengan benar!

1. Peraturan pemerintah $48 / 2008$ tentang pembiayaan pendidikan ditetapkan pada tanggal ....
a. 8 Juli 2008
c. 8 Agustus 2008
b. 8 Juni 2008
d. 17 Agustus 2008

2. Peraturan pemerintah $48 / 2008$ tentang pembiayaan pendidikan ditetapkan di Jakarta pada era presiden ...
a. Joko widodo
c. Susilo Bambang Yudhyono
b. Megawati
d. Soeharto

3. Pendanaan pendidikan menjadi tanggung jawab bersama antara ....
a. Pemerintah
c. Masyarakat
b. Pemerintah daerah
d. Semua jawaban benar

4. Salah satu pasal yang mendasari ditetapkannya peraturan pemerintah nomor 48 tahun 2008 adalah . ...
a. Pasal 46 ayat (3)
c. 26
b. Pasal 31
d. 29

5. Komponen pembiayaan pendidikan yang tercantum dalam peraturan pemerintah nomor 48/2008 diantaranya, kecuali ... .
a. Biaya satuan pendidikan
b. Biaya penyelenggaran dan pengelolaan
c. Biaya study tour
d. Biaya pribadi peserta didik 
6. Dalam peraturan pemerintah nomor 48/2008 bantuan biaya pendidikan dan beasiswa diatur pada pasal ....
a. 24
c. 27
b. 26 .
D. Semua jawaban salah

7. Tanggung jawab pendanaan satuan pendidikan yang dikelola oleh Pemerintah diluar negeri diatur oleh . ...
a. Peraturan presiden
b. Peraturan menteri
c. Peraturan pemerintah daerah
d. Peraturan gubernur

8. Dalam peraturan pemerintah nomor 48/2008 anggaran belanja negara setiap tahun untuk sektor pendidikan sekurang- kurangnya dialokasikan sebanyak ....
a. $45 \%$ dari APBN
c. $25 \%$ dari $\mathrm{APBN}$
b. $35 \%$ dari APBN
d. $20 \%$ dari APBN

9. Perencanaan anggaran pendidikan oleh satuan pendidikan tinggi harus sejalan dengan ....
a. Rencana pembangunan jangka panjang.
b. Rencana pembangunan jangka menengah.
c. Rencana kerja pemerintah.
d. Rencana persatuan.

10. Realisasi penerimaan dan pengeluaran dana pendidikan satuan pendidikan dibukukan dan dilaporkan sesuai standar akuntansi keuangan nirlaba yang berlaku bagi satuan pendidikan, merupakann isi dari . . . .
a. Pasal 70
c. Pasal 72
b. Pasal 71
d. Pasal 73

II. Jawab Essay dibawah ini.

1. Tanggung jawab masyarakat dibagi menjadi dua kategori, sebutkan!

2. Siapa saja yang memiliki tanggung jawab dalam pembiayaan pendidikan menurut peraturan pemerintah nomor 48/2008?

3.Sebutkan prinsip yang paling mendasar dalam kegiatan pembiayaan pendidikan!

4.Biaya investasi dibagi menjadi dua, sebutkan ! 
5. Jelaskan siapa saja yang berhak mendapatkan beasiswa menurut peraturan pemerintah nomor $48 / 2008$ !

Kunci Jawaban

1. A 6. C

2. C 7.B

3. D 8. D

4. A 9. D

5. C 10. C

Essay

1. Tanggung jawab masyarakat dalam pendanaan pendidikan dapat dibagi dalam 2 (dua) katagori, yaitu tanggung jawab pendanaan pendidikan oleh penyelenggara atau satuan pendidikan yang didirikan masyarakat dan tanggung jawab pendanaan pendidikan oleh masyarakat diluar penyelenggara dan satuan pendidikan yang didirikan masyarakat. Komponen biaya pendidikan pada penyelenggara atau satuan pendidikan yang didirikan masyarakat akan meliputi biaya investasi satuan pendidikan, biaya investasi penyelenggaraan dan/atau pengelolaan pendidikan, biaya operasi satuan pendidikan, biaya operasi penyelenggaraan dan/atau pengelolaan pendidikan, bantuan biaya pendidikan dan beasiswa.

2. Tanggung jawab bersama antara pemerintah, pemerintah daerah, dan masyarakat diantaranya :

a. Penyelenggara atau satuan pendidikan yang didirikan masyarakat.

b. Peserta didik, orang tua atau wali peserta didik.

c. Pihak lain yang mempunyai perhatian dan peranan dalam bidang pendidikan.

3. Prinsip keadilan, kecukupan, dan keberlanjutan.

4. Biaya investasi lahan pendidikan yang diselenggarakan pemerintah / pemerintah daerah dianggarkan dalam anggaran pemerintah/pemerintah daerah dan biaya investasi selain lahan pendidikan yang diselenggarakan pemerintah/pemerintah daerah dianggarkan dalam anggaran pemerintah/pemerintah daerah.

5. Dalam pasal 27 pemerintah dan pemerintah daerah sesuai kewenangannya disebutkan bahwa bantuan biaya pendidikan atau beasiswa kepada peserta didik yang orang tua atau walinya tidak mampu membiayai pendidikannya dan kepada peserta didik yang berprestasi. 


\section{BAB XI \\ PROFESIONALISME GURU \\ (UU 14 TAHUN 2005/PP 74 TAHUN 2008)}

\section{Pokok Bahasan}

Profesionalisme Guru (UU 14/2005, PP 74/2008)

\section{Capaian Kompetensi}

Pemahaman tentang pengelolaan tenaga pendidik, khususnya Guru berdasarkan Undang-Undang Nomor 14 Tahun 2005 dan Peraturan Pemerintah Nomor 74 Tahun 2008

\section{Petunjuk Belajar}

Membentuk kelompok, Membuat makalah dan Melakukan presentasi pada diskusi kelas

\section{Isi Materi}

a. Pengertian Profesionalisme

Istilah profesionalisme berasal dari profession. Dalam Kamus InggrisIndonesia, profession berarti pekerjaan. Arifin dalam buku Kapita Selekta Pendidikan mengemukakan bahwa profession mengandung arti yang sama dengan kata occupation atau pekerjaan yang memerlukan keahlian yang diperoleh melalui pendidikan atau latihan khusus.

Uzer Usman memberikan suatu kesimpulan bahwa kata professional yaitu suatu pekerjaan yang bersifat professional memerlukan beberapa bidang ilmu yang secara sengaja harus dipelajari dan kemudian diaplikasikan bagi kepentingan umum. Kata prifesional itu sendiri berasal dari kata sifat yang 
berarti pencaharian dan sebagai kata benda yang berarti orang yang mempunyai keahlian seperti guru, dokter, hakim, dan sebagainya.

Adapun mengenai pengertian profesionalisme itu sendiri adalah, suatu pandangan bahwa suatu keahlian tertentu diperlukan dalam pekerjaan tertentu yang mana keahlian itu hanya diperoleh melalui pendidikan khusus atau latihan khusus. Profesionalisme guru merupakan kondisi, arah, nilai, tujuan dan kualitas suatu keahlian dan kewenangan dalam bidang pendidikan dan pengajaran yang berkaitan dengan pekerjaan seseorang yang menjadi mata pencaharian. Sementara itu, guru yang profesional adalah guru yang memiliki kompetensi yang dipersyaratkan untuk melakukan tugas pendidikan dan pengajaran. Dengan kata lain, maka dapat disimpulkan bahwa pengertian guru profesional adalah orang yang memiliki kemampuan dan keahlian khusus dalam bidang keguruan sehingga ia mampu melakukan tugas dan fungsinya sebagai guru dengan kemampuan maksimal. Guru yang profesional adalah orang yang terdidik dan terlatih dengan baik, serta memiliki pengalaman yang kaya di bidangnya.

b. Latar Belakang Lahirnya UU 14 Tahun 2005 dan PP 74 Tahun 2008

Sebagaimana diamanatkan dalam UUD 1945 Pasal 31 ayat (3) yang berbunyi: "Pemerintah mengusahakan dan menyelenggarakan satu sistem pendidikan nasional yang meningkatkan keimanan dan ketakwaan serta akhlak mulia dalam rangka mencerdaskan kehidupan bangsa," dan ayat (5) yang berbunyi: "Pemerintah memajukan ilmu pengetahuan dan teknologi dengan menjunjung tinggi nilai-nilai agama dan persatuan bangsa untuk kemajuan peradaban serta kesejahteraan umat manusia.", UU Guru dan Dosen juga lahir bertujuan untuk memperbaiki pendidikan nasional, baik secara kualitas maupun kuantitas, agar sumber daya manusia Indonesia bisa lebih beriman, kreatif, inovatif, produktif, serta berilmu pengetahuan luas demi meningkatkan kesejahteraan seluruh bangsa. Perbaikan mutu pendidikan nasional yang dimaksud meliputi, Sistem Pendidikan Nasional, Kualifikasi serta Kompetensi Guru dan Dosen, Standar Kurikulum yang digunakan, serta hal lainnya.

UU Guru dan Dosen ini juga ditindak lanjuti dengan dibuatnya PP No. 74 Tahun 2008 tentang Guru, upaya peningkatan mutu pendidikan yang salah 
satunya melalui perbaikan nasib guru dengan memberikan kesempatan yang lebih besar pada guru untuk berperan dalam pengelolaan dan menentukan arah pendidikan disatuan pendidikan (Sekolah) khususnya di daerah bahkan nasional. Legalisasi peran guru dalam pengelolaan dan menentukan arah pendidikan membuka peluang untuk terwujudnya demokratisasi pendidikan disetiap level yang selama ini menjadi wacana.

Dalam kaitannya dengan Guru sebagai pendidik, maka pentingnya guru professional yang memenuhi standar kualifikasi diatur dalam pasal 8 Undangundang No.14 tahun 2005 tentang Guru Dan Dosen (UUGD) yang menyebutkan bahwa Guru wajib memiliki kualifikasi akademik, kompetensi, sertifikat pendidik, sehat jasmani dan rohani, serta memiliki kemampuan untuk mewujudkan tujuan pendidikan nasional. Lebih dalam lagi pada pasal 10 ayat (1) UUGD dan Pasal 28 ayat 30 dan PP 74 tahun 2008 tentang Guru dijelaskan bahwa kompetensi guru yang dimaksud meliputi:

1) Kompetensi pedagogik

kompetensi pedagogik adalah kemapuan mengelola pembelajaran peserta didik yang meliputi pemahaman terhadap peserta didik, perancangan dan pelaksanaan pembelajaran, evaluasi hasil belajar, dan pengembangan peserta didik untuk mengaktualisasikan berbagai potensi yang dimilikinya

2) Kompetensi kepribadian

kompetensi kepribadian adalah kemampuan kepribadian yang mantap, stabil, dewasa, arif, dan berwibawa, menjadi teladan bagi peserta didik, dan berakhlak mulia

3) Kompetensi profesional

kompetensi profesional adalah kemampuan penguasaan materi pembelajaran secara luas dan mendalam yang memungkinkan membimbing pesrta didik memenuhi standar kompetensi yang ditetapkan dalam Standar Nasional Pendidikan.

4) Kompetensi sosial

kemampuan guru sebagai bagian dari masyarakat untuk berkomunikasi dan bergaul secara efektif dengan peserta didik, sesama pendidik, tenaga kependidikan, orang tua/wali peserte didik, dan masyarakat sekitar. 
Kompetensi guru memiliki arti pengetahuan, keterampilan dan kemampuan yang dikuasai oleh seseorang yang telah menjadi bagian dari dirinya, sehingga ia dapat melakukan perilaku kognitif, apektif dan psikomotorik dengan sebaik-baiknya.

\section{c. Guru Profesional}

Dalam Pasal 1 UU No 14 tahun 2005 tentang Guru dan Dosen (selanjutnya disingkat UUGD) disebutkan bahwa Guru adalah pendidik profesional dengan tugas utama mendidik, mengajar, membimbing, mengarahkan, melatih, menilai, dan mengevaluasi peserta didik pada pendidikan anak usia dini jalur pendidikan formal, pendidikan dasar, dan pendidikan menengah.

Guru profesional sebagaimana dimaksud dalam pasal 1 adalah pekerjaan atau kegiatan yang dilakukan oleh seseorang dan menjadi sumber penghasilan kehidupan yang memerlukan keahlian, kemahiran, atau kecakapan yang memenuhi standar mutu atau norma tertentu serta memerlukan pendidikan profesi.

Menurut Oemar Hamalik, guru profesional, harus memiliki persyaratan yang meliputi: memiliki bakat sebagai guru, memiliki keahlian sebagai guru, memiliki keahlian yang baik dan terintegrasi, memiliki mental yang sehat, berbadan sehat, memiliki pengalaman dan pengetahuan yang luas, guru adalah manusia berjiwa pancasila, dan seorang warga negara yang baik.

Apa yang disampaikan Oemar Hamalik tersebut, tidak jauh beda dengan pasal yang tercantum dalam UUGD, pasal 8, 9, dan 10, sebagai berikut:

- Pasal 8: Guru wajib memiliki kualifikasi akademik, kompetensi, sertifikat pendidik, sehat jasmani dan rohani, serta memiliki kemampuan untuk mewujudkan tujuan pendidikan nasional.

- Pasal 9: Kualifikasi akademik sebagaimana dimaksud dalam Pasal 8 diperoleh melalui pendidikan tinggi program sarjana atau program diploma empat.

- Pasal 10: (1) Kompetensi guru sebagaimana dimaksud dalam Pasal 8 meliputi : kompetensi pedagogik, kompetensi kepribadian, kompetensi 
sosial, dan kompetensi profesional yang diperoleh melalui pendidikan profesi. Kemudian dalam tugas keprofesionalannya, guru mempunyai tugas:

a. merencanakan pembelajaran, melaksanakan proses pembelajaran yang bermutu, serta menilai dan mengevaluasi hasil pembelajaran;

b. meningkatkan dan mengembangkan kualifikasi akademik dan kompetensi secara berkelanjutan sejalan dengan perkembangan ilmu pengetahuan, teknologi, dan seni;

c. bertindak objektif dan tidak diskriminatif atas dasar pertimbangan jenis kelamin, agama, suku, ras, dan kondisi fisik tertentu, atau latar belakang keluarga, dan status sosial ekonomi peserta didik dalam pembelajaran;

d. menjunjung tinggi peraturan perundang-undangan, hukum, dan kode etik guru, serta nilai-nilai agama dan etika; dan

e. memelihara dan memupuk persatuan dan kesatuan bangsa.

\section{d. Mengukur Keprofesionalan Guru}

Sebagaimana sudah disebutkan, guru profesional setidaknya harus memenuhi empat kompetensi, yakni kompetensi profesional, kompetensi pedagogik, kompetensi kepribadian, dan kompetensi sosial.

Untuk mengukur keempat kompetensi tersebut, pemerintah menyelenggarakan program sertifikasi guru. Sertifikasi adalah proses pemberian sertifikat pendidik untuk guru yang diselenggarakan oleh perguruan tinggi yang memiliki program pengadaan tenaga kependidikan yang terakreditasi dan ditetapkan oleh Pemerintah, dilaksanakan secara objektif, transparan, dan akuntabel.

Sertifikasi Guru merupakan pemenuhan kebutuhan untuk meningkatkan kompetensi professional. Oleh karena itu, proses sertifikasi dipandang sebagai bagian esensial dalam upaya memperoleh sertifikasi kompetensi sesuai profesi yang dipilihnya. Bagi yang lulus sertifikasi, maka mereka mendapatkan sertifikat sebagai guru professional sesuai dengan mata pelajaran yang diampu.

Ketentuan lebih lanjut mengenai sertifikasi telah dibuat peraturan pemerintah yang memuat secara khusus berkaitan dengan sertifikasi. Aturan 
tersebut adalah Peraturan Pemerintah Nomor 74 Tahun 2008 tentang Guru dan Peraturan Menteri Pendidikan dan Kebudayaan Republik Indonesia Nomor 5 Tahun 2012 Tentang Sertifikasi Bagi Guru Dalam Jabatan.

Selain sertifikasi, sebelumnya harus dipenuhi terlebih dahulu kualifikasi akademik Guru. Dalam Peraturan Pemerintah Nomor 74 Tahun 2008, Kualifikasi Akademik adalah ijazah jenjang pendidikan akademik yang harus dimiliki oleh Guru sesuai dengan jenis, jenjang, dan satuan pendidikan formal di tempat penugasan.

Untuk meningkatkan Guru menjadi Guru professional, pendekatan yang digunakan secara sederhana dapat digambarkan sebai berikut:

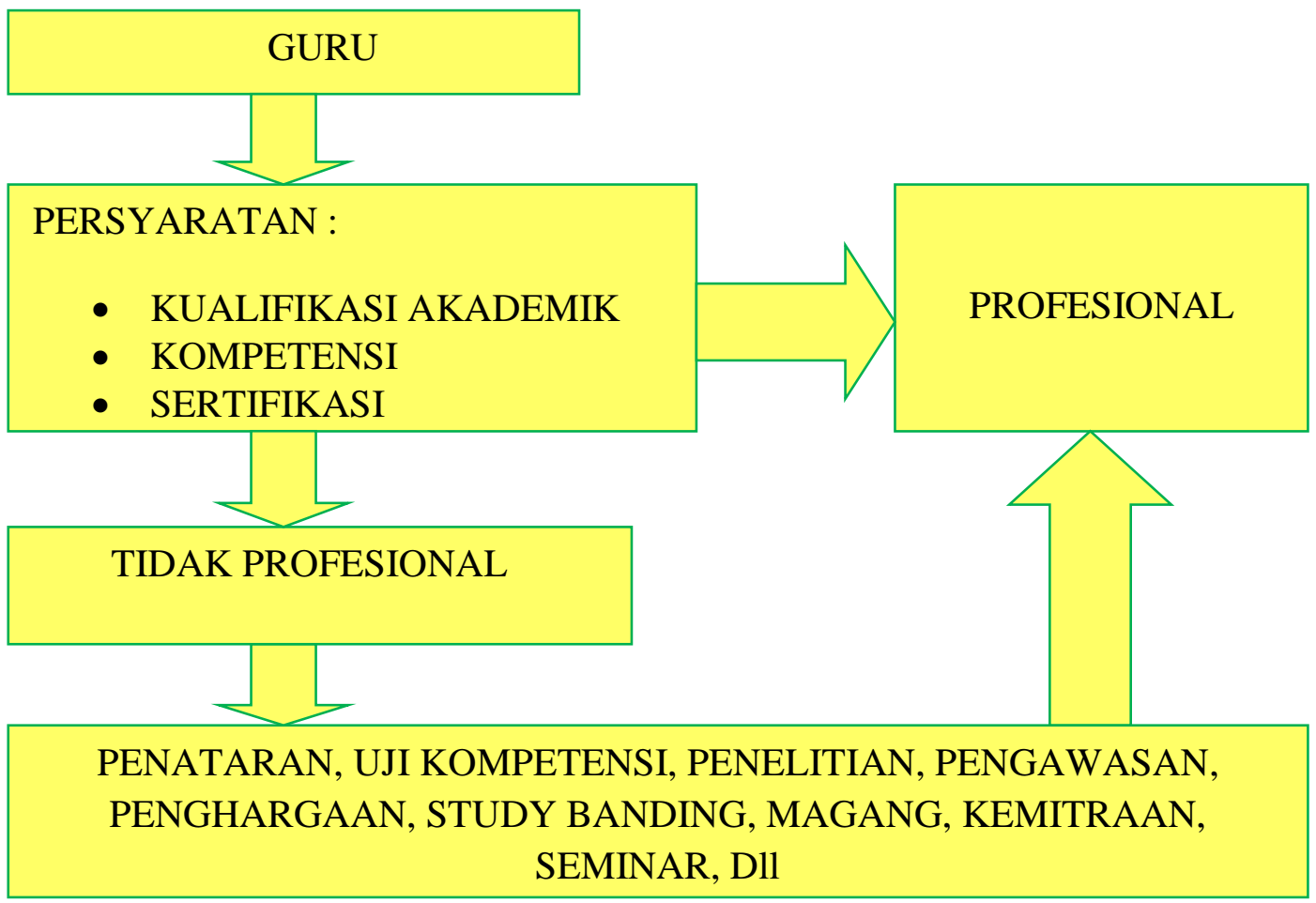

e. Penghargaan terhadap Guru Profesional

Sebagai bentuk penghargaan terhadap profesi guru, pemerintah memberikan reward (penghargaan) yang tercantum dalam PP 74 Tahun 2008. Pada bagian enam tentang penghargaan, yaitu:

1. kenaikan jabatan

2. uang atau barang

3. piagam 
4. tambahan angka kredit setara untuk kenaikan pangkat setingkat lebih tinggi 1 (satu) kali selama masa kariernya sebagai Guru.

5. Penyediaan biaya pemakaman dan/atau biaya perjalanan untuk pemakaman Guru yang gugur di Daerah Khusus.

Dan dalam PP 74 Tahun 2008 pasal 35 Sebagai penghargaan kepada Guru, Pemerintah menetapkan tanggal 25 November sebagai Hari Guru Nasional.

Begitu juga tercantum dalam UU No. 14 Tahun 2005, berupa:

1. memperoleh penghasilan di atas kebutuhan hidup minimum dan jaminan kesejahteraan sosial;

2. mendapatkan promosi dan penghargaan sesuai dengan tugas dan prestasi kerja;

3. memperoleh perlindungan dalam melaksanakan tugas dan hak atas kekayaan intelektual;

4. memperoleh kesempatan untuk meningkatkan kompetensi;

5. memperoleh dan memanfaatkan sarana dan prasarana pembelajaran untuk menunjang kelancaran tugas keprofesionalan;

6. memiliki kebebasan dalam memberikan penilaian dan ikut menentukan kelulusan, penghargaan, dan/atau sanksi kepada peserta didik sesuai dengan kaidah pendidikan, kode etik guru, dan peraturan perundangundangan;

7. memperoleh rasa aman dan jaminan keselamatan dalam melaksanakan tugas;

8. memiliki kebebasan untuk berserikat dalam organisasi profesi;

9. memiliki kesempatan untuk berperan dalam penentuan kebijakan pendidikan;

10. memperoleh kesempatan untuk mengembangkan dan meningkatkan kualifikasi akademik dan kompetensi;

11. memperoleh pelatihan dan pengembangan profesi dalam bidangnya.

Tujuan diberikan reward tersebut adalah untuk meningkatkan profesionalisme dan kesejahteraan guru. Bentuk kesejahteraan yang sekarang dapat dinikmati guru besertifikasi adalah mendapatkan tunjangan profesi 
yang besarnya satu kali gaji sesuai dengan golongan dan masa kerja masingmasing. Tunjangan tersebut tidak hanya guru yang berstatus PNS, tetapi juga swasta. Sedangkan guru yang belum besertifikasi, pemerintah memberikan TPP (Tunjangan Perbaikan Penghasilan) sebesar RP. 250.000/bulan.

5. Latihan-latihan

a. Pilihan Ganda

1. Istilah profesionalisme berasal dari profession yang berarti?
a. Pekerjaan
b. Kegiatan
c. Tindakan
d. Kelakuan
e. Keahlian

2. pekerjaan yang memerlukan keahlian yang diperoleh melalui pendidikan atau latihan khusus. Berikut adalah pengertian kata profesi menurut?
a. User usman
b. arifin
c. UU 14 Tahun 2005
d. PP 74 Tahun 2008
e. Oemar Hamalik

3. Kemampuan penguasaan materi pembelajaran secara luas dan mendalam yang memungkinkan membimbing pesrta didik memenuhi standar kompetensi yang ditetapkan dalam Standar Nasional Pendidikan. Berikut adalah penjelasan dari kompetensi guru, yaitu?
a. Kompetensi pedagogic
b. Kompetensi kepribadian
c. Kompetensi professional
d. Kompetensi social
e. Kompetensi akademik

4. pengetahuan, keterampilan dan kemampuan yang dikuasai oleh seseorang yang telah menjadi bagian dari dirinya, sehingga ia dapat melakukan 
perilaku kognitif, apektif dan psikomotorik dengan sebaik-baiknya.

Merupakan devinisi dari?
a. Sertifikasi
b. Kualifikasi Akademik
c. Kompetensi
d. Profesionalisme
e. Guru

5. Guru professional harus memili empat kompetensi, kecuali?
a. Kualifikasi pedagogic
b. Kualifikasi akademik
c. Kompetensi professional
d. Kompetensi social
e. Kompetensi kepribadian

6. Penetapan tanggal 25 November sebagai Hari Guru Nasional. Hal tersebut tercantum dalam?
a. $\quad$ PP 74 Tahun 2008 Pasal 31
b. PP 74 Tahun 2008 Pasal 32
c. $\quad$ PP 74 Tahun 2008 Pasal 35
d. UU 14 Tahun 2005 ayat 35
e. UU 14 Tahun 2005 Pasal 32

7. Ijazah jenjang pendidikan akademik yang harus dimiliki oleh Guru sesuai dengan jenis, jenjang, dan satuan pendidikan formal di tempat penugasan.Merupakan definisi dari?
a. Sertifikasi
b. Kualifikasi Akademik
c. Kompetensi
d. Profesionalisme
e. Piagam

8. Menurut Oemar Hamalik guru professional memiliki beberapa persyaratan, kecuali? 

a. memiliki bakat sebagai guru
b. memiliki keahlian sebagai guru
c. memiliki keahlian yang baik dan terintegrasi
d. memiliki mental yang sehat, berbadan sehat
e. memiliki ekonomi yang cukup

9. kemapuan mengelola pembelajaran peserta didik yang meliputi pemahaman terhadap peserta didik, perancangan dan pelaksanaan pembelajaran, evaluasi hasil belajar, dan pengembangan peserta didik untuk mengaktualisasikan berbagai potensi yang dimilikinya. Merupakan definisi dari?
a. Kompetensi pedagogic
b. Kompetensi kepribadian
c. Kompetensi professional
d. Kompetensi social
e. Kompetensi akademik

10. kemampuan guru sebagai bagian dari masyarakat untuk berkomunikasi dan bergaul secara efektif dengan peserta didik, sesama pendidik, tenaga kependidikan, orang tua/wali peserte didik, dan masyarakat sekitar. Merupakan definisi dari?
a. Kompetensi pedagogic
b. Kompetensi kepribadian
c. Kompetensi professional
d. Kompetensi social
e. Kompetensi akademik 


\section{b. ESSAY}

1. Apa yang dimaksud Profesionalisme Guru?

2. Jelaskan kenapa guru harus memiliki 4 kompetensi?

3. Dalam keprofesionalannya guru mempunyai tugas?

4. Dalam PP 74 Tahun 2008 sebagai bentuk penghargaan terhadap profesi guru, pemerintah memberikan reward (penghargaan) berupa?

5. Jelaskan kenapa pemerintah mengadakan sertifikasi guru?

\section{Kunci Jawaban}

a. Pilihan ganda

1. A

2. B

3. $\mathrm{C}$

4. $\mathrm{C}$

5. B

6. C

7. B

8. $\mathrm{E}$

9. A

10. D

\section{b. ESSAY}

1. Profesionalisme Guru mempunyai pengertian suatu sifat yang harus ada pada seorang guru dalam menjalankan pekerjaannyasehingga guru tersebut dapat menjalankan pekerjaannya dengan penuh tanggungjawab serta mampu untuk mengembangkan keahliannya tanpa mengganggu tugas pokok guru tersebut.

2. Guru harus memiliki 4 kompetensi dikarenakan guru disekolah memiliki peran ganda, yaitu disamping guru seorang manajer yang akan mengelola proses pembelajaran mulai dari pembelajaran sampai evaluasi, guru juga sekaligus sebagai pelaksana aktivitas pembelajaran dan melakukan pengontrolan atas kecakapan dan prestasi siswa-siswanya. Sehingga guru harus memiliki seperangkat pengetahuan, sikap, nilai dan keterampilan 
yang harus dikuasai dan ditampilkan dalam melaksanakan tugas pokok, fungsi dan tanggungjawab terhadap pekerjaan dan jabatan yang disandangnya

3. Tugas guru dalam keprofesionalannya:

a. merencanakan pembelajaran, melaksanakan proses pembelajaran yang bermutu, serta menilai dan mengevaluasi hasil pembelajaran;

b. meningkatkan dan mengembangkan kualifikasi akademik dan kompetensi secara berkelanjutan sejalan dengan perkembangan ilmu pengetahuan, teknologi, dan seni;

c. bertindak objektif dan tidak diskriminatif atas dasar pertimbangan jenis kelamin, agama, suku, ras, dan kondisi fisik tertentu, atau latar belakang keluarga, dan status sosial ekonomi peserta didik dalam pembelajaran;

d. menjunjung tinggi peraturan perundang-undangan, hukum, dan kode etik guru, serta nilai-nilai agama dan etika; dan

e. memelihara dan memupuk persatuan dan kesatuan bangsa.

4. Penghargaan terhadap guru professional:

a. kenaikan jabatan

b. uang atau barang

c. piagam

d. tambahan angka kredit setara untuk kenaikan pangkat setingkat lebih tinggi 1 (satu) kali selama masa kariernya sebagai Guru.

e. Penyediaan biaya pemakaman dan/atau biaya perjalanan untuk pemakaman Guru yang gugur di Daerah Khusus.

5. Tujuan Sertifikasi guru adalah untuk menentukan kelayakan guru dalam melaksanakan tugas sebagai pemegang peranan pentingdalam pelajaran dan mewujudkan tujuan pendidikan nasional. Dengan guru yang bersertifikat pendidik melalui program sertifikasi guru merupakan salah satu langkahpemerintah dalam membangun pendidikan yang berkualitas dan berkompeten baik disaat sekarang atau dimasa yang akan dat 


\section{BAB XII}

\section{PROPESIONALISME PENGAWAS PENDIDIKAN}

\section{Poko bahasan}

Keberhasilan penyelenggaraan Pendidikan yang berkualitas sangat terkait erat dengan keberhasilan peningkatan kompetensi dan profesionalisme pendidik dan tenaga kependidikan, Peran tersebut berkaitan dengan tugas pokok pengawas dalam melakukan supervisi manajerial dan akademik serta pembinaan peran pembinaan

\section{Kompetisi yang akan di capai}

Setelah menerima materi ini Mahasiswa dapat memahami tentang kepengawasan atau supervise yang propesional dan berkarakter menueut permendiknas nomer 12 tahun 2007

\section{Petunjuk Pemebelajaran}

Untuk dapat mengikuti dan memahami materi ini maka mahasiswa di harapkan

1.Membaca terlebih dahulu materi yang akan di sampaikan

2.Mendengarkan presentasi yang akan di sampaikan

3. Berdiskusi antar teman tentang materi yang sudah di sampaikan.

\section{Konten atau isi materi pembelajaran}

\section{A. Pengertian Pengawas sekolah}

Pengawas Sekolah adalah guru pegawai negeri sipil yang diberi tugas, tanggung jawab dan wewenang secara penuh oleh pejabat yang berwenang untuk melakukan pengawasan pendidikan di sekolah dan melaksanakan penilaian, pembinaan dari segi teknis pendidikan dan administrasi pada satuan pendidikan pra sekolah, dasar dan menengah.

Kepengawasan adalah kegiatan pengawas sekolah dalamn menyusun program pengawasan, melaksanakan program pengawasan, evaluasi hasil pelaksanaan program, dan melaksanakan pembimbingan dan pelatihan profesionalisme guru.

\section{B. Kedudukan Pengawas Sekolah}

Pengawas sekolah adalah pejabat fungsional yang berkedudukan sebagai pelaksana teknis untuk melakukan pengawasan dan pembinaan pendidikan terhadap sejumlah sekolah tertentu yang ditunjuk dan ditetapkan. 


\section{JENIS PENGAWAS SEKOLAH}

\section{Pengawas Taman Kanak-Kanak}

Yaitu pengawas sekolah yang memiliki tugas, tanggungjawab, wewenang dan hak secara penuh dalam melaksanakan tugas pengawasan pada Pendidikan Usia Dini Formal baik negeri maupun swasta dalam teknis penyelenggaraan dan pengembangan program pembelajaran di TK.

\section{Pengawas Sekolah Dasar}

Yaitu pengawas sekolah yang memiliki tugas, tanggungjawab, wewenang dan hak secara penuh dalam melaksanakan tugas pengawasan pada sejumlah sekolah baik negeri maupun swasta untuk pengelolaan sekolah, bidang pengembangan untuk seluruh mata pelajaran Sekolah Dasar kecuali mata pelajaran pendidikan agama dan pendidikan jasmani dan kesehatan.

\section{Pengawas Mata Pelajaran/Rumpun Mata Pelajaran}

Yaitu pengawas sekolah yang memiliki tugas, tanggungjawab, wewenang dan hak secara penuh dalam melaksanakan tugas pengawasan pada mata pelajaran atau rumpun mata pelajaran tertentu pada sejumlah sekolah baik negeri maupun swasta.

\section{Pengawas Pendidikan Luar Biasa}

Yaitu pengawas sekolah yang memiliki tugas, tanggung jawab, wewenang dan hak secara penuh dalam melaksanakan tugas pengawasan pada sejumlah sekolah baik negeri maupun swasta pada sekolah luar biasa di lingkungan Kementerian Pendidikan Nasional untuk seluruh mata pelajaran.

\section{Pengawas Bimbingan dan Konseling}

Yaitu pengawas sekolah yang memiliki tugas, tanggung jawab, wewenang dan hak secara penuh dalam melaksanakan tugas pengawasan pada sejumlah sekolah baik negeri maupun swasta pada kegiatan bimbingan dan konseling.

\section{RUANG LINGKUP TUGAS PENGAWAS SEKOLAH}

Ruang lingkup tugas pengawas adalah melakukan Pembimbingan dan Pelatihan Profesional Guru dan Pengawasan yang ekuivalensinya dengan 24 jam pembelajaran tatap muka dalam satu minggu. (Pasal 54 PP No. 74 Tahun 2008 Tentang Guru) 


\section{E. TUGAS POKOK PENGAWAS SEKOLAH}

Tugas pokok pengawas sekolah adalah melaksanakan tugas pengawasan akademik dan manajerial pada satuan pendidikan yang meliputi penyusunan program pengawasan, pelaksanaan pembinaan, pemantauan pelaksanaan 8 (delapan) Standar Nasional Pendidikan, penilaian, pembimbingan dan pelatihan professional guru, evaluasi hasil pelaksanaan program pengawasan, dan pelaksanaan tugas kepengawasan di daerah khusus.

Rincian tugas pokok pengawas berdasarkan jabatan pengawas :

\section{Pengawas Sekolah Muda}

a) Menyusun program pengawasan

b) Melaksanakan pembinaan guru

c) Memantau pelaksanaan standar isi, standar proses, standar kompetensi lulusan, standar penilaian

d) Melaksanakan penilaian kinerja guru

e) Melaksanakan evaluasi hasil pelaksanaan program pengawasan pada sekolah binaan

\section{Pengawas Sekolah Madya}

a) Menyusun program pengawasan

b) Melaksanakan pembinaan guru dan/atau Kepala Sekolah

c) Memantau pelaksanaan standar isi, standar proses, standar kompetensi lulusan, standar pendidik dan tenaga kependidikan, standar sarana dan prasarana, standar pengelolaan, standar pembiayaan dan standar penilaian pendidikan

d) Melaksanakan penilaian kinerja guru dan/atau kepala sekolah

e) Melaksanakan evaluasi hasil pelaksanaan program pengawasan pada sekolah binaan

f) Menyusun program pembimbingan dan pelatihan profesional guru dan/atau kepala sekolah di KKG/MGMP/MGP dan/atau KKKS/MKKS dan sejenisnya

g) Melaksanakan pembimbingan dan pelatihan profesional guru dan/atau kepala sekolah

h) Melaksanakan pembimbingan dan pelatihan kepala sekolah dalam menyusun program sekolah, rencana kerja, pengawasan dan evaluasi, kepemimpinan sekolah, dan sistem informasi dan manajemen 
i) Mengevaluasi hasil pembimbingan dan pelatihan profesional guru dan/atau kepala sekolah

j) Membimbing pengawas sekolah muda dalam melaksanakan tugas pokok

\section{Pengawas Sekolah Utama}

a) Menyusun program pengawasan

b) Melaksanakan pembinaan guru dan Kepala Sekolah

c) Memantau pelaksanaan standar isi, standar proses, standar kompetensi lulusan, standar pendidik dan tenaga kependidikan, standar sarana dan prasarana, standar pengelolaan, standar pembiayaan dan standar penilaian pendidikan

d) Melaksanakan penilaian kinerja guru dan kepala sekolah

e) Melaksanakan evaluasi hasil pelaksanaan program pengawasan pada sekolah binaan

f) Mengevaluasi hasil pelaksanaan program pengawasan tungkat Kabupaten/Kota atau Provinsi

g) Menyusun program pembimbingan dan pelatihan profesional guru dan kepala sekolah di KKG/MGMP/MGP dan KKKS/MKKS dan sejenisnya

h) Melaksanakan pembimbingan dan pelatihan profesional guru dan kepala sekolah

\section{F. Pengawas propesional}

Peraturan Menteri Pendidikan Nasional Nomor 12 Tahun 2007 Tentang Standar Pengawas Sekolah atau Madrasah berisi standar kualifikasi dan kompetensi pengawas sekolah dan madrasah. Standar kualifikasi menjelaskan persyaratan akademik dan nonakademik untuk diangkat menjadi pengawas sekolah. Standar kompetensi memuat seperangkat kemampuan yang harus dimiliki dan dikuasai pengawas sekolah untuk dapat melaksanakan tugas pokok, fungsi dan tanggung jawabnya,yang terdiri atas enam(6) dimensi kompetensi yang dikembangkan menjadi 36 kompetensi inti,yang terdiri dari

\section{Kompetisi Kepribadian}

Kompetensi kepribadian pengawas sekolah adalah kemampuan pengawas sekolah dalam menampilkan dirinya atau performance diri sebagai pribadi yang:

a) bertanggungjawab dalam melaksanakan tugas pokoknya

b) kreatif dalam bekerja dan memecahkan masalah 
c) ingin tahu hal-hal baru tentang ilmu pengetahuan, teknologi dan seni

d) memiliki motivasi kerja dan bisa memotivasi orang lain dalam bekerja.

\section{Kompetisi Sosial.}

Kompetensi sosial pengawas sekolah mengindikasikan dua keterampilan yang harus dimiliki pengawas sekolah yakni :

(1) keterampilan berkomunikasi baik lisan atau tulisan termasuk keterampilan bergaul

dan

(2) keterampilan bekerja dengan orang lain baik secara individu maupun secara kelompok/

organisasi.

Keterampilan ini mensyaratkan tampilnya sosok pribadi pengawas yang luwes, terbuka, mau menerima kritik serta selalu memandang positif orang lain.

\section{KOMPETENSI SUPERVISI MANAJERIAL}

Kompetensi supervisi manajerial adalah kemampuan pengawas sekolah dalam melaksanakan pengawasan mana $\neg$ jerial yakni menilai dan membina kepala sekolah dan tenaga kependidikan lain yang ada di sekolah dalam mempertinggi kualitas pengelolaan dan administasi sekolah. Standar administrasi dan pengelolaan sekolah secara konseptual dan operasional tersirat dan tersurat dalam rumusan kompetensi inti kepala sekolah (Permendiknas No. 13 Tahun 2007) khususnya pada dimensi kompetensi mana-jerial. Selain itu dalam kompetensi manajerial pengawas sekolah, pengawas dituntut juga untuk menguasai program dan kegiatan bimbingan konseling serta memantau pelaksa-naan standar nasional pendidikan di sekolah binaannya. Untuk itu pengawas sekolah harus menguasai teori, konsep serta prinsip tentang metode dan teknik supervisi pendidikan berikut aplikasinya dalam penyusunan program dan praktek pengawasan manajerial. Berikut ini kompetensi inti yang harus dimliki pengawas sekolah dalam dimensi kompetensi supervisi manajerial.

1. menguasai pengetahuan tentang metode, teknik dan prinsip-prinsip supervisi dalam meningkatkan mutu pendidikan

2. menguasai teknik menyusun program pengawasan berdasarkan visi, misi, tujuan dan program pendidikan sekolah binaan

3. menyusun metode kerja dan instrumen yang diperlukan untuk melaksanakan tugas pokok dan fungsi pengawasan di sekolah binaannya. 
4. teknik menyusun laporan hasil-hasil pengawasan dan menindaklanjutinya untuk perbaikan program pengawasan berikutnya pada sekolah binaannya

5. membina kepala sekolah dalam pengelolaan dan administrasi satuan pendidikan berdasarkan manajemen peningkatan mutu pendidikan di sekolah

6. membina kepala sekolah dan guru dalam melaksanakan bimbingan konseling di sekolah

7. mendorong guru dan kepala sekolah dalam mereflek-sikan hasil-hasil yang dicapainya untuk menemukan ke-lebihan dan kekurangan dalam melaksanakan tugas pokoknya

8. memantau pelaksanaan standar nasional pendidikan dan memanfaatkan hasilhasilnya untuk membantu kepala sekolah mempersiapkan akreditasi sekolahnya.'

\section{Kopetensi Supervisi Akademik}

Kompetensi supervisi akademik adalah kemampuan pengawas sekolah dalam melaksanakan pengawasan akade $\neg$ mik yakni menilai dan membina guru dalam rangka memper-t/nggi kualitas proses pembelajaran yang dilaksanakannya agar berdampak terhadap kualitas hasil belajar siswa

Kompetensi supervisi akademik intinya adalah membina guru dalam meningkatkan mutu proses pembelajaran. Oleh sebab itu sasaran supervisi akademik adalah guru dalam pro-ses belajar mengajar (pembelajaran). Materi pokok dalam proses pembelajaran adalah (penyusunan silabus dan RPP, pemilihan strategi/metode/teknik pembelajaran, penggunaan media dan teknologi informasi dalam pembelajaran, menilai proses dan hasil pembelajaran serta penelitian tindakan kelas). Berikut adalah kompetensi inti dari dimensi kompeᄀtensi supervisi akademik.

a. menguasai konsep, prinsip, teori dasar, karakteristik dan kecenderungan perkembangan tiap mata pelajaran

b. menguasai konsep, prinsip, teori dasar, karakteristik dan kecenderungan proses pembelajaran/pembimbingan tiap mata pelajaran

c. membimbing guru dalam menyusun silabus mata pelajaran berdasarkan standar isi, standar kompetensi dan kompetensi dasar serta prinsip-prinsip pengem-bangan KTSP 
d. membimbing guru dalam memilih dan menggunakan strategi/metode/teknik pembelajaran/'bimbingan setiap mata pelajaran membimbing guru dalam menyusun rencana pelaksanaan pembelajaran tiap mata pelajaran

e. membimbing guru dalam menyususn rencana pelaksanaan pembelajaran tiap mata pelajaran.

f. membimbing guru dalam melaksanakan pembelajaran di laboratorium dan di lapangan

g. membimbing guru dalam mengelola, merawat, mengem -bangkan dan menggunakan media serta fasilitas pembe-lajaran/bimbingan

h. membimbing guru dalam memanfaatkan teknologi informasi untuk pembelajaran/bimbingan

\section{Kopotensi Evaluasi Pendidik}

Kompetensi evaluasi pendidikan adalah kemampuan pengawas sekolah dalam kegiatan mengumpulkan, mengolah, menafsirkan dan menyimpulkan data dan informasi untuk menentukan tingkat keberhasilan pendidikan. Materi pokok kompetensi evaluasi pendidikan adalah penilaian proses dan hasil belajar, penilaian program pendidikan, penilaian kinerja guru, kinerja kepala sekolah dan kinerja sekolah. Penilaian itu sendiri diartikan sebagai proses memberikan pertimbangan berdasarkan kriteria yang telah ditentukan. Oleh sebab itu ciri dari kegiatan penilaian adalah adanya obyek yang dinilai, adanya kriteria yang dijadikan indikator keberhasilan dan adanya interpretasi dan judgement. Setiap kegiatan penilaian akan menghasilkan data hasii penilaian yang harus diolah dan dianalisis untuk pengambilan keputusan.

a) Dimensi kompetensi evaluasi pendidikan terdiri atas enam kompetensi inti yakni:

b) menyusun kriteria dan indikator keberhasilan pembela $\neg$ jaran/bimbingan

c) membimbing guru dalam menentukan aspek-aspek yang penting dinilai dalam

pembelajaran/bimbingan

d) menilai kinerja kepala sekolah, guru dan staf sekolah dalam melaksanakan tugas pokok dan tanggungjawabnya dalam meningkatkan mutu pendidikan 
e) memantau pelaksanaan pembelajaran/bimbingan dan hasil belajar siswa serta menganalisisnya untuk perba-ikan mutu pembelajaran/bimbingan

f) membina guru dalam memanfaatkan hasil penilaian untuk perbaikan mutu pendidikan dan pembelajaran/ bimbingan

g) mengolah dan menganalisis data hasil penilaian kinerja kepala sekolah, guru dan staf sekolah

\section{Kopetensi Penelitian Dan Pengembangan}

Kompetensi penelitian dan pengembangan adalah kemarnpuan pengawas sekolah dalam merencanakan dan melaksanakan penelitian pendidikan/pengawasan serta menggunakan hasil-hasilnya untuk kepentingan peningkatan mutu pendidikan. Penelitian adalah kegiatan mengumpulkan, mengolah, menafsirkan dan menyimpulkan data dan informasi untuk memecahkan masalah praktis dan atau untuk pengembangan ilmu pengetahuan. Penelitian merupakan metode ilmiah yakni memecahkan masalah dengan menggunakan logika berpikir yang didukung oleh data empiris.

Logika berpikir tampak dalam prosesnya dengan menempuh langkahlangkah yang sistematis mulai dari pengumpulan data, mengolah dan menafsirkan data, menguji data sampai menarik kesimpulan. Data dikatakan empiris sebab menggambarkan apa yang terjadi di lapangan. Dalam kompetensi penelitian materi yang perlu dikuasai pengawas sekolah antara lain pendekatan, metode dan jenis penelitian, merencanakan dan melaksa $\neg$ nakan penelitian, mengolah dan menganalisis data, menulis laporan hasil penelitian sebagai karya tulis ilmiah serta memanfaatkan hasil-hasil penelitian

\section{F. Kesimpulan}

Pengawas sekolah adalah tenaga kependidikan profesional yang memiliki tugas dan tanggung jawab serta wewenang penuh untuk melakukan pembinaan dan pengawasan pendidikan disekolah baik bidang akademik maupun bidang manajerial.

Dalam melaksanakan tugas kepengawasannya seorang pengawas sekolah harus dapat menjadi teladan/contoh bagi seluruh warga sekolah, dalam bersikap dan bertindak. Untuk mewujudkan hal tersebut seorang pengawas dapat 
mengimplementasikan seluruh sikap dan tindakannya melalui aktualisasi dari kristalisasi nilai-nilai pendidikan budaya dan karakter bangsa.

\section{G. Sumber Pendukung}

Kementerian Pendidikan Nasional. 2007. Peraturan Menteri Pendidikan Nasional Republik Indonesia Nomor 12 tahun 2007 Tentang Standar Pengawas Sekolah/Madrasah. Jakarta.

Nana Sudjana. 2006. Standar Mutu Pengawas. Jakarta: Depdiknas

Undang-Undang Republik Indonesia Nomor 20 Tahun 2003. Sistem Pendidikan Nasional. Jakarta.

Tita Lestari. 2009. Penyusunan Program, Pelaksanaan dan Pelaporan Hasil Pengawasan. Materi ToT Calon Pengawas. Jakarta: Direktorat Tenaga Kependidikan, Ditjen PMPTK, Departemen Pendidikan Nasional.

Uhar Suharsaputra. 2009. Membangun Pengawasan Pendidikan Berorientasi Mutu.

Latihan

1. Apa sajakah kegiatan seorang pengawas di sekolah?
A. Menyusun peogram pengawasan
B. Melaksanakan Program Pengawasan
C. Melaksanakan pelatihan dan bimbingan profesionalisme guru
D. Benar semua

2. Pengawas sekolah pada satuan pendidikan manapun di lingkungan pendidikan dasar dan mengeah berkewjiban melaksanakan pengembangan kopetensi berkelanjutan yang dapat di lakukan dengan cara?
A. Mengikuti Pelatihan yang di lakukan oleh lembaga Seperti LPMP, P4TK
B. Mengikuti seminar yang di selagarakan oleh perguruan tinggi pendidikan
C. Menyelengarakan Kopetensi pelatihan di sekolah
D. Belajar sendiri di rumah.

3. Ada berpakah tugas poko setandar seorang pengawas sekolah:
A. 4
C. 9
B. 7
C. 8

4. Pengawas sekolah berkewajiban melihat kelebihan dan kekurangan pelaksanaan Delapan setandar nasional pendidikan pada sekolah binaanya, untuk itu upaya yang harus di lakukan oleh seorang pengawas adalah?
A. Mendorong sekolah melakukan akreditasi sekolah
B. Menilai kinerja sekolah
C. Mendorong Kepala sekolah untuk melakuakan Evaluasi setipa kegiatan
D. Menilai Fasilitas sekolah yang mendukung setandar pendidikan 
5. Apasajakah tugas seorang pengawas sekolah madya;
A. Menyusun program pengawasan
B. Melaksanakan pembinaan guru dan/atau Kepala Sekolah
C. Mengantikan kepala sekolah
D. A dan B benar.

6. Keterampilan yang harus dikuasai pengawas sekolah agar dapat menjalin hubungan dengan berbagia pihak adalah
A. Teknik Berkomunikasi
B. Tekhnik Berkolaborasi
C. Teknik Bernegoisasi
D. Teknik Menipu.

7. Bidang Iptek yang harus di kuasi oleh seorang pengawas sekolah adalah?
A. pisikologi Sosial
B. Sosiologi Pendidikan
C. Teknologi Informasi Dan komunikasi
D. Sumber daya manusia

8.Undang-undang nomer berapakah yang mengatur tentang pengawas sekolah
A. Nomor 12 Tahun 2007
B. Nomor 13 Tahun 2007
C. Nomor 14 Tahun 2007
D. Nomor 15 Tahun 2007

9. Tekhnik Supervisi yang tepat digunakan dalam meningkatkan kinerja sekolah adalah
A. Rapat dengan guru, kepala sekolah dan stafnya
B. kunjungan Kelas untuk melihat cara belajarnya
C. Wawancara dengan berbagai Pihak
D. Melakukan observasi guru

10. Dalam melakukan supervisai akademikacuan yang relafan di gunakan pengawas sekolah adalah/
A. Standar Kopotensi setandar lulusan
B. Standar Isi
C. Standar penilean
D. Standar Proses 


\section{Kunci Jawaban : Plihan Ganda}

1. D

2. C

3. D

4. C

5. D

6. A

7. C

8. A

9. $\mathrm{A}$

10. B

\section{Kunci Jawaban Esai}

1. Pengawas Sekolah adalah guru pegawai negeri sipil yang diberi tugas, tanggung jawab dan wewenang secara penuh oleh pejabat yang berwenang untuk melakukan pengawasan pendidikan di sekolah dan melaksanakan penilaian, pembinaan dari segi teknis pendidikan dan administrasi pada satuan pendidikan pra sekolah, dasar dan menengah

2. Tugas pokok pengawas sekolah adalah melaksanakan tugas pengawasan akademik dan manajerial pada satuan pendidikan yang meliputi penyusunan program pengawasan, pelaksanaan pembinaan, pemantauan pelaksanaan 8 (delapan) Standar Nasional Pendidikan, penilaian, pembimbingan dan pelatihan professional guru, evaluasi hasil pelaksanaan program pengawasan, dan pelaksanaan tugas kepengawasan di daerah khusus

3. Peraturan Menteri Pendidikan Nasional Nomor 12 Tahun 2007 Tentang Standar Pengawas Sekolah atau Madrasah berisi standar kualifikasi dan kompetensi pengawas sekolah dan madrasah. Standar kualifikasi menjelaskan persyaratan akademik dan nonakademik untuk diangkat menjadi pengawas sekolah

4. Ada 3 yaituPengawas Sekolah muda, pengawas sekolah Madya, Pengawas utama

5. Ada delapan, 1, program pengawasan, 2 pelaksanaan binaan, 3 pemantauan pelaksana, 4 standar nasional, 5 penilean, 6 pembimbingan dan pelatihan, 7 evaluasi, 8 Pelaksanaan tugas 


\section{REFERENSI}

Kumpulan Peraturan Perundangan dalam Bidang Pendidikan

Sulfemi, Wahyu Bagja. (2013). Pengaruh Persepsi Siswa atas Kemampuan Pedagogik Guru dan Motivasi Belajar Siswa Terhadap Prestasi Belajar Ilmu Pengetahuan Sosial Siswa (Survei di SMK Swasta Kabupaten Bogor). Edutecno. 7 (2), 17-26.

Sulfemi, Wahyu Bagja. (2016). Perundang-Undangan Pendidikan. Bogor: Program Studi Administrasi Pendidikan STKIP Muhammadiyah Bogor.

Sulfemi, Wahyu Bagja. (2016). Modul Pembelajaran Ilmu Sosial dan Budaya Dasar. Bogor: STKIP Muhammadiyah Bogor.

Sulfemi, Wahyu Bagja. (2016). Kompetensi Profesionalisme Guru Indonesia dalam Menghadapi MEA. Prosiding Seminar Nasional STKIP Muhammadiyah Bogor. 1 (1), 62-77.

Sulfemi, Wahyu Bagja. (2016). Hubungan antara Persepsi Guru pada Kepemimpian Kepala Sekolah dan Motivasi Guru dengan Kinerja guru dalam Proses Pembelajaran di SMA Negeri 1 Ciomas. Fascho : Kajian Pendidikan dan Sosial Kemasyarakatan, 5 (1), 36-55.

Sulfemi, Wahyu Bagja. (2016). Hubungan Persepsi Peserta Didik Tentang Kompetensi Guru Mata Pelajaran Sejarah dengan Hasil Belajar Mata Pelajaran Sejarah di Kelas X SMA Negeri 1 Pamijahan Kabupaten Bogor. Fascho, $5(2), 52-70$.

Sulfemi, Wahyu Bagja. (2016). Kompetensi Profesionalisme Guru Indonesia dalam Menghadapi MEA. Prosiding Seminar Nasional STKIP Muhammadiyah Bogor. 1 (1), 62-77

Sulfemi, Wahyu Bagja. (2017). Analisis Pengaruh Motivasi Dan Disiplin Terhadap Kinerja Guru (Studi Kasus di SMA Negeri 1 Pamijahan Kabupaten Kabupaten Bogor). Prosiding Seminar Nasonal STKIP Muhammadiyah Bogor. 1 (1), 342-357

Sulfemi, Wahyu Bagja. (2018). Manajemen Kurikulum Di Sekolah. Bogor: Visi Nusantara Maju.

Sulfemi, Wahyu Bagja. (2018). Modul Manajemen Pendidikan Non Formal. Bogor : STKIP Muhammadiyah Bogor.

Http://Www.Tipspendidikan.Site/2014/11/Kumpulan-Permendiknas-Uu-Dan-PpTentang.Html

http://retorika69.blogspot.com/2016/04/sistem-pendidikannasional.htmlhttps://gumonounib.wordpress.com/2010/06/23/undangundang-sisdiknas-dari-masa-ke-masa/

https://gumonounib.wordpress.com/2010/06/23/undang-undang-sisdiknas-dari-masa-kemasa/https://id.wikipedia.org/wiki/Prosedur 
http://cokinew.blogspot.co.id/2016/02/pengertian-prosedur-menurut-para-ahli.html http://ainamulyana.blogspot.com/2016/08/tata-urutan-peraturan-perundang.html http://referensi.elsam.or.id/2014/11/uu-nomor-20-tahun-2003-tentang-sistempendidikan-nasional/

http://herysusantolimpung.blogspot.co.id/2012/03/v-behaviorurldefaultvmlo.html http://www.sjdih.depkeu.go.id/fullText/2005/14TAHUN2005UU.htm https://akhmadsudrajat.wordpress.com/2010/04/14/download-peraturan-pemerintahnomor-17-tahun-2010-tentang-pengelolaan-dan-penyelenggaraanpendidikan/

http://pendidikan60detik.blogspot.co.id/2015/11/proses-pembuatan-peraturanperundangan.html

https://alisadikinwear.wordpress.com/2012/05/11/landasan-penyusunan-peraturanperundangan/

http://arifin-zaenalarifin.blogspot.co.id/2013/06/legal-drafting-asas-asaspemberlakuan.html

http://www.markijar.com/2016/06/pengertian-dan-macam-macam-kebijakan.html http://www.rijal09.com/2016/03/kebijakan-pendidikan.html

http://www.setneg.go.id/index.php?option=com_content\&task=view\&id=3647

http://oktaseiji.wordpress.com/2011/04/24/kebijakan-pendidikan-di-indonesia/ http://ekarahmayuliani.web.unej.ac.id/2015/12/20/kebijakan-pemerintah-di-bidangpendidikan/

https://goenable.wordpress.com/2012/01/08/standar-pengelolaan-pendidikan// http://ninukdwiwuriyani.blogspot.co.id/2010/01/standar-pengelolaan pendidikan.html https://anatomiestreetsoldier.wordpress.com/2010/06/26/pengelolaan-pendidikan/ https://goenable.wordpress.com/2012/01/08/standar-pengelolaan-pendidikan// http://ninukdwiwuriyani.blogspot.co.id/2010/01/standar-pengelolaan pendidikan.html https://anatomiestreetsoldier.wordpress.com/2010/06/26/pengelolaan-pendidikan/ UU 14 Tahun 2005 dan PP 74 Tahun2008

https://www.academia.edu/7095598/Profesionalisme_Guru_Analisis_UU_No_14_Tahu n_2005_tentang_Guru_dan_Dosen 